\title{
Understanding the Hysteresis Loop Conundrum in Pharmacokinetic I Pharmacodynamic Relationships
}

\author{
Christopher Louizos ${ }^{1}$, Jaime A. Yáñez ${ }^{2}$, M. Laird Forrest ${ }^{3}$, Neal M. Davies ${ }^{1}$ \\ ${ }^{1}$ Faculty of Pharmacy, University of Manitoba, Winnipeg, Manitoba, Canada. ${ }^{2}$ Ocular Pharmacokinetics and Disposition. \\ Alcon Research, Ltd., a Novartis Company, Fort Worth, TX, USA. ${ }^{3}$ School of Pharmacy, Department of Pharmaceutical \\ Chemistry, University of Kansas, Lawrence, Kansas, USA.
}

Received, February 4, 2014; Revised, March 4, 2014; Accepted, March 5, 2014; Published, March 7, 2014

\begin{abstract}
Hysteresis loops are phenomena that sometimes are encountered in the analysis of pharmacokinetic and pharmacodynamic relationships spanning from pre-clinical to clinical studies. When hysteresis occurs it provides insight into the complexity of drug action and disposition that can be encountered. Hysteresis loops suggest that the relationship between drug concentration and the effect being measured is not a simple direct relationship, but may have an inherent time delay and disequilibrium, which may be the result of metabolites, the consequence of changes in pharmacodynamics or the use of a non-specific assay or may involve an indirect relationship. Counter-clockwise hysteresis has been generally defined as the process in which effect can increase with time for a given drug concentration, while in the case of clockwise hysteresis the measured effect decreases with time for a given drug concentration. Hysteresis loops can occur as a consequence of a number of different pharmacokinetic and pharmacodynamic mechanisms including tolerance, distributional delay, feedback regulation, input and output rate changes, agonistic or antagonistic active metabolites, uptake into active site, slow receptor kinetics, delayed or modified activity, time-dependent protein binding and the use of racemic drugs among other factors. In this review, each of these various causes of hysteresis loops are discussed, with incorporation of relevant examples of drugs demonstrating these relationships for illustrative purposes. Furthermore, the effect that pharmaceutical formulation has on the occurrence and potential change in direction of the hysteresis loop, and the major pharmacokinetic / pharmacodynamic modeling approaches utilized to collapse and model hysteresis are detailed.
\end{abstract}

This article is open to POST-PUBLICATION REVIEW. Registered readers (see "For Readers") may comment by clicking on ABSTRACT on the issue's contents page.

\section{INTRODUCTION}

A central tenet of clinical pharmacotherapeutics is that there often exists a relationship between drug concentration and pharmacological and toxicological effects for drugs. The most common pharmacokinetic-pharmacodynamic

(PK-PD) models assume that plasma concentration is in equilibrium and proportional with the effect site (biophase) concentration. In its simplest form a plasma drug concentration versus effect graph demonstrates a direct linear relationship between the two variables where effect is directly proportional to drug concentrations at the active site and this relationship is independent of time [1] (Figure 1a).Where equation 1 is:

$$
E=S * C
$$

$\mathrm{E}$ is the effect, $\mathrm{C}$ is the drug concentration and $\mathrm{S}$ is the slope parameter. This linear function model does not predict a maximum pharmacological effect $\left(\mathrm{E}_{\max }\right)$. The relationship between drug concentration and pharmacological effect more often follows a sigmoidal $\mathrm{E}_{\max }$ model (Hill equation) (Figure 1b). This simple mathematical relationship is based on receptor theory that defines the drug concentration effect relationship with two parameters $\mathrm{E}_{\max }$ and $\mathrm{EC}_{50}$ (the concentration producing $50 \%$ of the maximum effect). It allows for differences in the shape of this relationship, where $n$ is the number of molecules combining with each receptor molecule that affects the shape of the curve. The relationship between drug concentration at the receptor and the response is defined using equation 2 .

Corresponding Author: Dr. Neal M. Davies, Faculty of Pharmacy, University of Manitoba, Winnipeg, Manitoba, Canada. Email: neal_davies@umanitoba.ca 


$$
E=\frac{\left(E_{\max }\right) *\left(C^{n}\right)}{E C_{50}{ }^{n}+C^{n}}
$$

$E$ is the observed effect, $E_{\max }$ is the theoretical maximal effect that can be attained, $C$ is the concentration, $\mathrm{EC}_{50}$ is the $C$ value that produces an effect equivalent to $50 \%$ of the theoretical maximal effect and $n$ is a slope factor parameter that determines the steepness of the curve. The time courses of drug effect and concentrations may not be completely superimposable. Time-dependent concentration-effect relationships exist with a time lag present between measurable effect and measurable concentration. In these cases, when pharmacodynamics and drug concentration data are connected in time series at a later point compared with a previous time point there is a discordance in the plasma concentration versus effect relationship with respect to time. Hence, the magnitude of pharmacological effect either increases or decreases at any given plasma drug concentration. The term "hysteresis" has been utilized to describe this time lag. The term "hysteresis" is derived from the Greek husterēsis or husteros meaning 'shortcoming, to come late or to come behind'. Hysteresis is the dependence of a system on both its current and past environments. Figure 1c and d present the graphical evidence of a temporal relationship of dependence between the pharmacological effect and the drug plasma concentration. As the data modeling field in pharmaceutical science examining the concentration versus effect relationships and simulations has grown, there has been some debate regarding the terminology used to describe these phenomena when encountered. It has been suggested that instead of using the term clockwise hysteresis, the moniker "proteresis" should be employed. "Proteresis" is a term also derived from the Greek language with proteros meaning 'former, before or to mark an earlier event'. Similarly, instead of stating that a "counter-clockwise" or "anticlockwise" hysteresis is present it was proposed to simply state the vernacular of 'hysteresis' to avoid redundancy [2]. However, the term 'proteresis' has not become the conventional lexicon and most studies in the literature still utilize the appellatives 'clockwise' or 'counter-clockwise' hysteresis. For consistency and clarity in this review clockwise hysteresis will be used instead of proteresis, and counter-clockwise hysteresis instead of simply hysteresis or anti-clockwise hysteresis.

In the counter-clockwise scenario (Figure $1 \mathrm{c}$ ) there is often non-instantaneous distribution of a drug to the effect site (biophase), as the drug appearance is delayed into the pharmacodynamic (PD) effect site at a slower rate than that in which it appears in plasma, this temporal delay in delivery results in a mismatch between declining concentrations and the response [3, 4]. When the biophase is not in the central compartment, it exhibits a counter-clockwise hysteresis loop when followed over time (Figure 1c). In this instance, there is a small effect at a given drug concentration; however, after some time has passed the same drug concentration gives rise to a greater measured effect than expected. Thus, the same drug concentration produces two different magnitudes of pharmacological effects depending on the temporal sequence in which the effect is measured. Counterclockwise hysteresis has been generally defined as the process in which effect increases with time for a given drug concentration [5]. These phenomena can be caused by uptake into an active site, cascade activity, active metabolites or sensitization (Table 1) [5].

In the opposite scenario a hysteresis loop may also occur where a clockwise hysteresis loop is evident, for example if tolerance is developed to a drug such as an opioid (Figure 1d). Here it can be seen that the same plasma concentration has a greater effect early on in temporal sequence and that after some time the effect diminishes at the same plasma concentration. In the case of clockwise hysteresis the measured effect decreases with time. These phenomena can be mechanistically induced by active antagonistic metabolites, tolerance, learning effects, or feed-back regulation etc. (Table 1) $[5]$.

An analysis of the pharmaceutical literature using PubMed, EMBASE and Google Scholar searches indicates that there are many plausible mechanistic proposed reasons for explaining the findings of hysteresis loops in drug concentration versus effect plots (Tables 1-3). Situations that may lead to a clockwise hysteresis are the development of tolerance to a drug, antagonistic metabolites that are formed as the drug is metabolized, downregulation of receptors and feedback regulation [6]. Some potential causes for counter-clockwisehysteresis include distribution delay between the plasma and effect site, response delay, sensitization 
of receptors, the formation and subsequent accumulation of active metabolites through drug metabolism as well as up regulation of receptors after ongoing exposure [6,7]. Once this type of hysteresis loop relationship has been discovered further mathematical modeling, such as the effect compartmental modeling, or one of its many modifications such as indirect modeling, can be applied to the data to take into account lag times, formation of active metabolites or multiple receptor sites in order to mechanistically define and simplify the concentration-effect relationship [1].

As hysteresis loops become readily evident during attempts to correlate the pharmacokinetic (PK) measurement [concentration (C)] of a drug with its measured PD measurement [effect (E)], an accurate determination of the PD measurement is critical.[8] In general, most of the clinical pharmacology study designs include in vivo $\mathrm{PK}$ and in vivo $\mathrm{PD}$ endpoint measurements; however, in the case of antibiotics or immunosuppressants it is common to have in vivo non-steady state dosing of drug, and the sampled matrix is used to determine in vitro $\mathrm{PD}$ effect, which can make the interpretation of hysteresis more straightforward. However, in early stages of drug discovery/development analytical assays are sometimes incapable of differentiating parent drug from its metabolite(s) and therefore would not be able to account for the presence/degree of in vivo pharmacological active metabolite(s) [8]. From the pharmacological and mechanistic point of view, counter-clockwise and clockwise hysteresis loops are a phenomenon that occurs under specific conditions, and the amount, activity and potency of parent and metabolite ratio is a key concept in the development and direction of a determined hysteresis.

Counter-clockwise hysteresis loops in PK-PD relationships could be explained and defined [319] as a consequence of a number of factors illustrated below in Figure 2.

\section{Counter-clockwise Hysteresis}

1. Disequilibrium caused by a temporal displacement can occur because of rate limiting steps:

Step A: Instantaneous equilibrium between $\mathrm{C}$ and effect site concentrations $\left(\mathrm{C}_{\mathrm{e}}\right)$ is not attained, which results in a temporal displacement (between $\mathrm{C}$ and $\mathrm{C}_{\mathrm{e}}$ ), where $\mathrm{C}_{(\mathrm{t})}$ in plasma and $\mathrm{C}_{\mathrm{e}}$ in the effect site are not identical and $\mathrm{C}_{(\mathrm{t})}>\mathrm{C}_{\mathrm{e}}$.[8]
Step B: The rate of change of $\mathrm{C}_{e}$ is much greater than the rates of pharmacological receptor activation/deactivation $\left(\mathrm{R}^{*}\right)$. For instance the number of activated receptors $\left(\mathrm{R}^{*}\right)$ is not reflective of $\mathrm{C}_{e}$ at time $(\mathrm{t})$, resulting in a temporal displacement (between $\mathrm{C}_{\mathrm{e}}>$ and $\mathrm{R}^{*}$ ). [8]

Step C: The overall rate of conversion of signal transduction induced by $\mathrm{R}^{*}$ to measured $\mathrm{E}$ is much less than the rate of change of $\mathrm{R}^{*}$ so that $\mathrm{E}_{(\mathrm{t})}$ is not equal to $\mathrm{R}^{*}(\mathrm{t})$, resulting in temporal displacement between $\mathrm{R}^{*}>$ and $\mathrm{E}$. The concentration (C) of drug binding with a receptor $(\mathrm{R})$ forms a transient (CR) drug-receptor complex and this altered complex is affected by the receptor association and dissociation on and off the receptor. $K_{d}$ is the receptor dissociation rate constant and is equal to the ratio of $\mathrm{K}_{\text {off }} / \mathrm{K}_{\text {on }}$.

2. Transformation of a drug or prodrug into a metabolite(s) with agonist actions (MPCA / MPPCA or MPNCA) are formed from the parent drug (D or E) and are included in the contribution of the combined measurement of E.

Step D: Common Receptor-Common Transduction Mechanism $\mathrm{MPC}_{\mathrm{A}}$ or MPPCA is a competitive agonist or competitive partial agonist with lower intrinsic activity, for which it occupies the same receptor $\left(\mathrm{R}^{*}\right)$ as the parent drug concentration [E $\mathrm{E}_{\max } \mathrm{MPCA}$ or $\mathrm{E}_{\max } \mathrm{MPPCa}$ is less than $E_{\max (C)}$

Step E: Separate Receptor-Common Transduction Mechanism. Metabolite with noncompetitive agonist actions (MNCA) occupies a different receptor but the same effect is achieved through a similar mechanism.

Step J: Separate Receptor Separate Transduction Mechanism MNCA is a noncompetitive agonist, for which a different pharmacological receptor (R2) is occupied but the same $E$ achieved through a different mechanism.

3. Step K: Changes in PD over time. PD has a distinct temporal component. For instance, up regulation of receptor response $\left(\mathrm{R}^{*}\right)$ (Step $\mathrm{K}$ ) (sensitization) when the $\mathrm{EC}_{50}$ might reduce over time.

4. Indirect physiological mechanism of drug action with changes in PD over time. A biosensor process leads to a positive 
modulation in production $\mathrm{K}_{\text {in }}$ or a negative change in degradation $\mathrm{K}_{\text {out }}$ of the biosignal may occur and be transduced (Step L) into an E.

5. The measurement of $\mathrm{C}_{(\mathrm{t})}$ is not specific and analysis should seek to measure the active component.

A. Total (unbound and bound) drug analyzed is being measured over time rather than unbound concentration of drug being measured over time and time-dependent protein binding due to protein binding changes over time are occurring such that unbound pharmacologically active concentration reduces with time.[9]

B. Total achiral (all enantiomers) drug concentration is being measured over time rather than enantiospecific concentration of a racemic drug through the use of non-stereospecific assays [10]. Stereospecific pharmacokinetics and pharmacodynamics are occurring leading to 1 . Stereospecific disequilibirum 2. Stereospecific metabolism and/or 3. Stereospecific changes in PD occurring.

a) Common Receptor-Common Transduction Mechanism Stereospecific Competitive Agonist/Partial Agonism.

b) Separate Receptors-Common Transduction Mechanisms. One enantiomer with non-competitive agonist actions occupies a different receptor but the same effect is achieved through a similar mechanism.

c) Separate Receptor Separate Transduction Mechanism. One enantiomer is a non-competitive agonist, for which a different pharmacological receptor (R2) is occupied but the same E achieved through a different mechanism.

C. Total (parent drug + metabolites) concentration together are being measured by a non-specific analytical assay (i.e. radioimmunoassay, radioactive assay, or high performance liquid chromatographic assay, etc.), which is non-specific for the parent drug such that an assumed $\mathrm{E}$ vs. C plot is in actuality an E vs. C+MPCA or E vs. C+MPPCA plot.

5). A specific analytical assay has been developed to measure $\mathrm{C}$, however, an unknown or unidentified agonist metabolite is adding to the $\mathrm{E}$.

\section{Clockwise hysteresis}

Clockwise hysteresis loops in PK-PD relationships could be explained and defined as a consequence of a number of factors illustrated below in Figure 3.
1. Disequilibrium caused by a temporal displacement that occurs because of a major rate limiting step: Step A: Disequilibrium occurs when $\mathrm{C}_{\mathrm{e}}$ temporally precedes $\mathrm{C}_{(\mathrm{t})}$. For instance, the rate of equilibration between arterial plasma concentrations (compartment delivering drug to effect site) and venous plasma concentrations (sampling compartment for drug concentration analysis) is significantly less between arterial concentrations and $\mathrm{C}_{\mathrm{e}}$ such that $\mathrm{C}_{(\mathrm{t})}$ is not equal to $\mathrm{Ce}_{(\mathrm{t})}$, resulting in temporal displacement (between $\mathrm{C}_{(\mathrm{t})}$ and $\mathrm{C}_{\mathrm{e}}$.)

2. Metabolite(s) with antagonistic actions (MpCAn) are formed. Step D: Common ReceptorCommon Mechanism. MpCAn is a competitive antagonist with no intrinsic activity, for which the same receptor $\left(\mathrm{R}^{*}\right)$ is occupied as the administered drug concentration but it lacks pharmacological activity $\left[E_{\max (\text { MANTCA }) \sim 0} \quad<<<E_{\max (\mathrm{C})}\right]$ so that receptor blockade occurs.[8]

Step G: Common Receptor-Common Transduction Mechanism. MPPA is a partial competitive agonist with low intrinsic activity, for which it occupies the same receptor $\left(\mathrm{R}^{*}\right)$ as the parent drug concentration [ $\mathrm{E}_{\max (\mathrm{MPOa})}$ is less than $\left.\mathrm{E}_{\max (\mathrm{C})}\right]$

Step J: Separate Receptor-Separate Mechanism. $\mathrm{MpCA}$ is a non-competitive antagonist (reverse agonist), for which it interacts with a different receptor (R1) than the drug concentration administered and has opposing effects over the measured $\mathrm{E}_{(\mathrm{t})}$.

Step N. Changes in PD over time. PD has a measurable temporal component. For instance, with tolerance down regulation of receptors leads to $\mathrm{EC}_{50}$ to increase and/or the $E_{\max }$ would decrease overtime.

3. Indirect mechanism of drug action with changes in PD over time. A biosensor process leads to a negative modulation of production $\mathrm{K}_{\mathrm{in}}$ or a positive increase in degradation in $\mathrm{K}_{\text {out }}$ of the biosignal may occur and be transduced (Step O) into $\mathrm{E}$. P).

4. Counter regulatory feedback regulation (Step

5. The measurement of $\mathrm{C}_{(\mathrm{t})}$ is not-specific.

A. Total (unbound and bound) drug measured is being measured over time rather than unbound free concentration of drug being measured over time and time-dependent protein binding such as the protein binding changes over time are occurring such that unbound pharmacologically active concentration decreases with time [9]. 

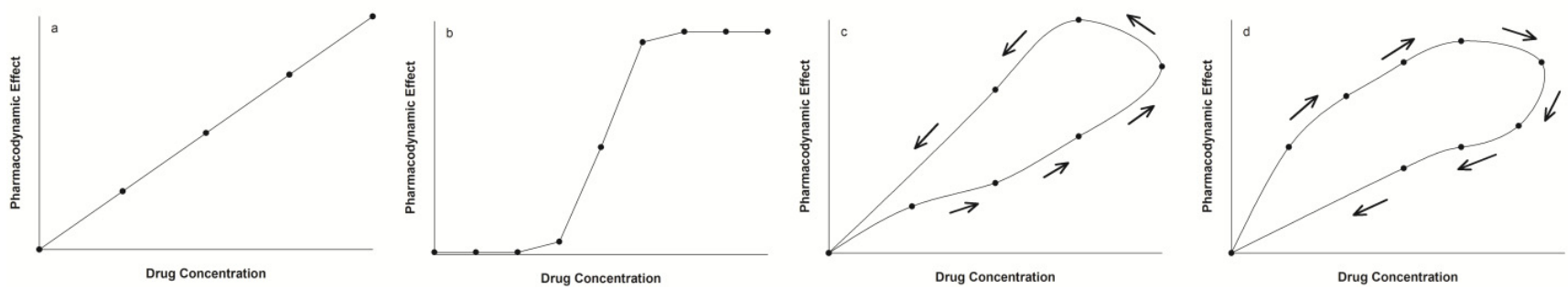

Figure 1. (a) Representation of a linear relationship between plasma concentration of a drug and measured pharmacological effect (b) Representation of a Sigmoidal Emax model relationship between plasma concentration of a drug and measured pharmacological effect (c) Representation of counter-clockwise hysteresis between plasma concentration and measured pharmacological effect (d) Representation of clockwise hysteresis between plasma concentration and measured pharmacological effect.

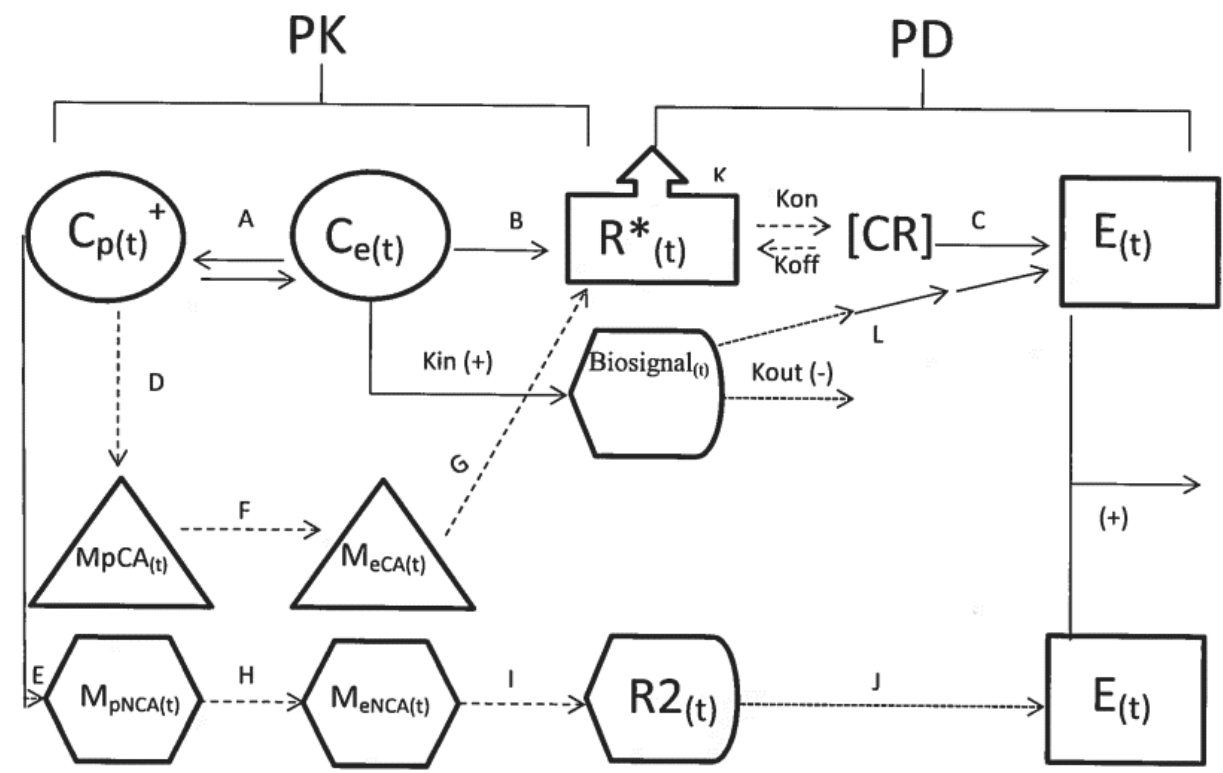

Figure 2. Factors Influencing Counter-clockwise Hysteresis

$\mathrm{C}_{\mathrm{p}(\mathrm{t})}=$ Plasma parent drug concentration, $\mathrm{C}_{\mathrm{e}(\mathrm{t})}=$ "Effect site" concentration, $\mathrm{R}_{(\mathrm{t})}=$ Receptor site, $\mathrm{E}_{(\mathrm{t})}=$ Effect, MPCA(t) $=$ Metabolite(s) in plasma which are competitive agonists, $\operatorname{MeCA}(\mathrm{t})=$ Metabolite(s) in "Effect site" which are competitive agonists, MPNCA $(\mathrm{t})=$ Metabolite(s) in plasma which are competitive agonists /(MPPCA) partial agonists which have noncompetitive agonist action acting on a different receptor BUT same Effect, MeNCA(t) = Metabolite(s) in "Effect site" which are competitive agonists which have non-competitive agonist action acting on a different receptor BUT same Effect, $\mathrm{R} 2=$ Alternate receptor site (with same Effect).

B. Total achiral (all enantiomers) drug concentration is being measured over time rather than enantiospecific concentration of a racemic drug through the use of non-stereospecific assays [10].

Stereospecific pharmacokinetics and pharmacodynamics are occurring leading to 1 . Stereospecific Disequilibrium, 2. Stereospecific Metabolism and/or 3. Stereospecific Changes in PD occurring. A. Common Receptor-Common Mechanism Competitive Antagonism, where one enantiomer is active and the other has affinity but no activity.
B. Total (parent drug + metabolites) concentration together are being measured by a non-specific analytical assay is being utilized (i.e. radioimmunoassay, radioactive assay, or high performance liquid chromatographic assay, etc.) that is non-specific for the parent drug such that an assumed E vs. C plot is in actuality an E vs. $\mathrm{C}+\mathrm{MpCAN}$ or $\mathrm{E}$ vs. $\mathrm{C}+\mathrm{MpCA}$ plot.

A specific analytical assay has been developed to measure parent compound concentration, however, an unknown or unidentified antagonist metabolite is adding to the E. 


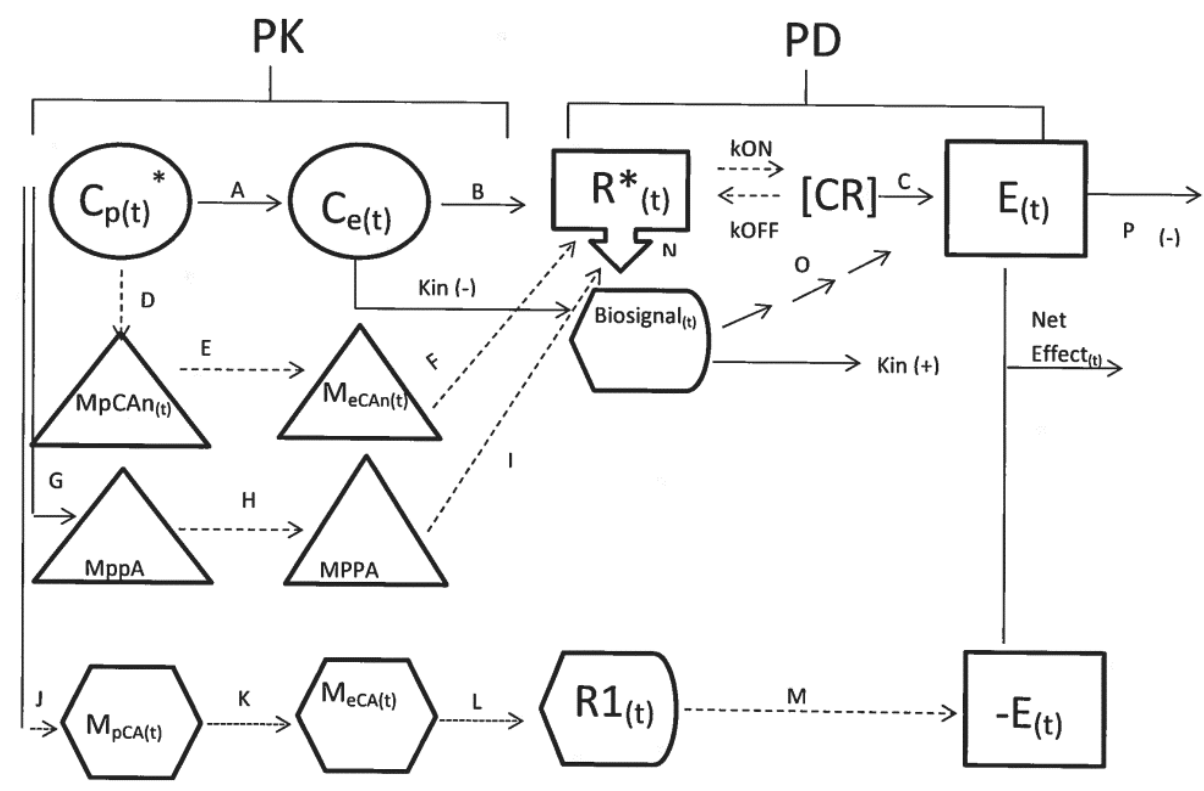

Figure 3. Factors Influencing Clockwise Hysteresis

$\mathrm{C}_{\mathrm{p}(\mathrm{t})}=$ Plasma parent drug concentration, $\mathrm{Ce}(\mathrm{t})=$ "Effect site" concentration, $\mathrm{R}^{*}(\mathrm{t})=$ Receptor site, $\mathrm{E}(\mathrm{t})=$ Effect, $\mathrm{MpCAn}(\mathrm{t})$ $=$ Metabolite $(\mathrm{s})$ in plasma which are competitive antagonists, MeCAn $(\mathrm{t})=$ Metabolite $(\mathrm{s})$ in "Effect site" which are competitive antagonists, $\operatorname{MpCA}(\mathrm{t})=$ Metabolite(s) in plasma which are competitive antagonists which have competitive agonist action acting on a different receptor BUT same Effect, MeCA(t) = Metabolite(s) in "Effect site" which are competitive antagonists which have competitive agonist action acting on a different receptor BUT same Effect, R1 = Alternate receptor site (with same but opposite Effect).

Table 1. Mechanistic Explanations for Hysteresis

\section{Counter-clockwise Hysteresis}

Sensitization (up regulation of receptors)

Input rate

Distribution delay into the site of Effect

Active agonist metabolite

Indirect effect( positive input or negative output)

Slow receptor kinetics

Time dependent protein binding

Racemic drugs and non-stereospecific assays

\section{Clockwise Hysteresis}

Tolerance (down regulation "desensitation" of receptors)

Input rate

Disequilibrium between arterial and venous concentrations

Active antagonistic metabolite

Indirect effect ( negative input or positive output)

Feedback regulation

Time dependent protein binding

Racemic drugs and non-stereospecific assays
The following overview of hysteresis loops aims to provide a comprehensive rather than exhaustive appraisal of the available pharmaceutical and biomedical literature in which hysteresis in either direction has been observed or studied. The goal of this article is to provide the reader with a more comprehensive understanding of the mechanistic reasons underlying why these phenomena can occur, provide examples of which drugs and group of drugs have been reported to exhibit these characteristics (Table 2 and 3), the effect that pharmaceutical formulation may have on the occurrence and change in direction of a hysteresis loop, and the main pharmacokinetic- pharmacodynamic modeling approaches utilized to further understand hysteresis relationships.

\section{COUNTER-CLOCKWISE HYSTERESIS}

A counter-clockwise hysteresis loop may signify an increasing pharmacological effect compared with earlier temporal pharmacological effects obtained with the same plasma concentration of drug. There are a variety of examples in the literature that suggest this type of pharmacokinetic / pharmacodynamic relationship as demonstrated in Table 2 [11-79, 298-312, 318, and 327-329]. A counter-clockwise hysteresis may mechanistically 
manifest due to a variety of underlying mechanisms as discussed below.

\section{Distribution Delay into Site of Effect}

Counter-clockwise hysteresis loops can occur because of a distribution delay between the systemic drug concentration and the time to reach the effect site. This is the most commonly encountered underlying mechanism responsible for the finding of a counter-clockwise hysteresis loop. Effect-concentration is time-dependent and an indirect link is made between the two variables.

For example, a delay for a drug to be transported from the systemic circulation to its site of action to elicit a response has been reported for $\Delta$-9-tetrahydrocannabinol (THC) after intravenous, oral or smoking administration, and after various intravenous doses [107]. It was observed that counter-clockwise hysteresis was evident after intravenous and smoking administration because THC takes a finite time in order to equilibrate with one of its sites of action (brain). However, it was also observed that after oral administration no hysteresis loop was evident because more time was allowed for penetration into the brain [107]. In the case of intravenous and smoking administration, the time necessary to reach equilibrium was approximately 15 minutes (Figure 4a). Furthermore, it can be observed that the counter-clockwise hysteresis loop was evident after all the intravenous doses (Figure 4b), indicating that this phenomenon is both dose and route-independent [107]. It can be observed that the location and the protective barriers surrounding the active site, in this case the brain, plays a critical role in the occurrence of hysteresis. As the brain possesses multiple protective barriers such as the blood-brain barrier (BBB) it could be expected that a delay in reaching the site of action would occur. This type of hysteresis was also observed for morphine after subcutaneous administration $(14 \mu \mathrm{mol} / \mathrm{kg})$ to rats with renal failure in which counter-clockwise hysteresis was developed between anti-nociceptive activity and morphine plasma concentrations, which correlated with an equilibrium delay as the consequence of the ability of morphine to cross the BBB [58].

The organic nitrate isosorbide dinitrate (ISDN) exhibited counter-clockwise hysteresis after intravenous infusion $(0.133 \mathrm{mg} / \mathrm{min}$ for $15 \mathrm{~min})$ or sublingual (5 mg) administration (Figure 5) [44]. It was observed that the changes in standing systolic pressure were greater during the declining phase than in the ascending phase after IV and sublingual administration [44], this correlated with previous studies after oral administration [108].
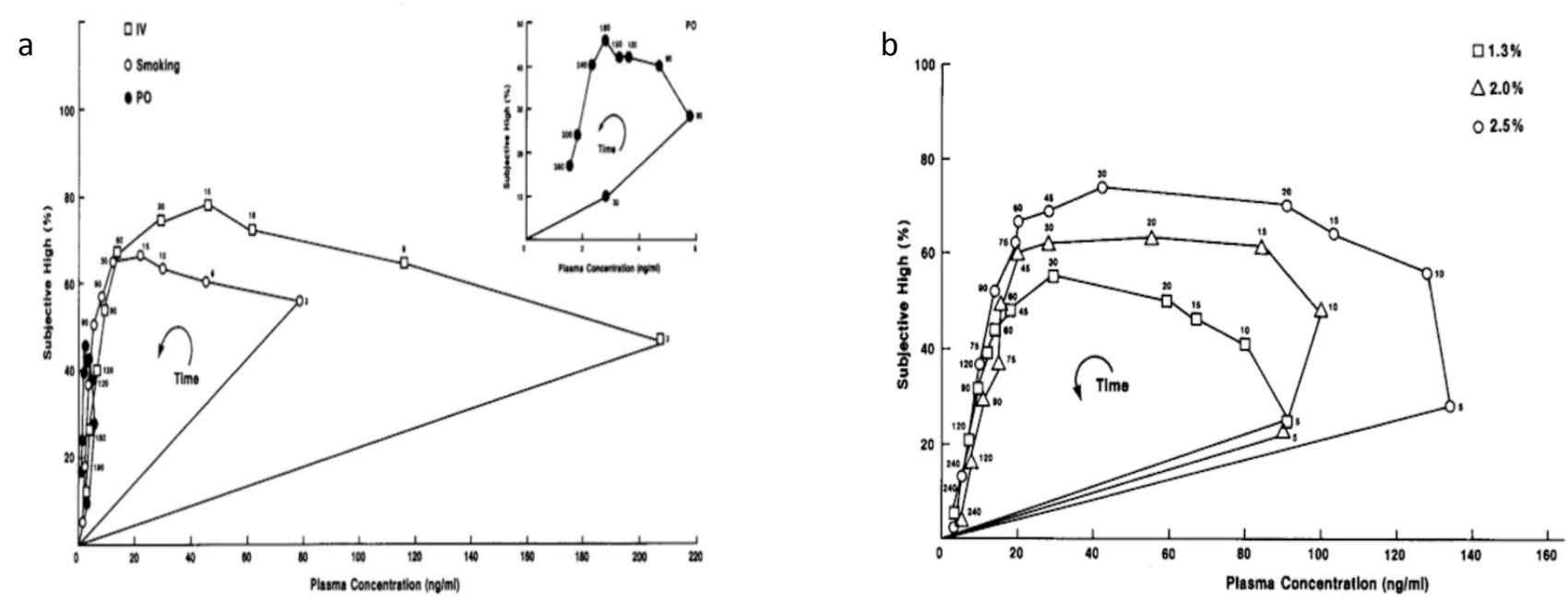

Figure 4. Counter-clockwise hysteresis of $\Delta$-9-tetrahydrocannabinol (THC) plasma concentrations versus self-reported subjective "High" effect (a) different routes of administration and (b) different dosages. Reprinted by permission from Macmillan Publishers Ltd: Clinical pharmacology and therapeutics, [107], copyright 1984. 


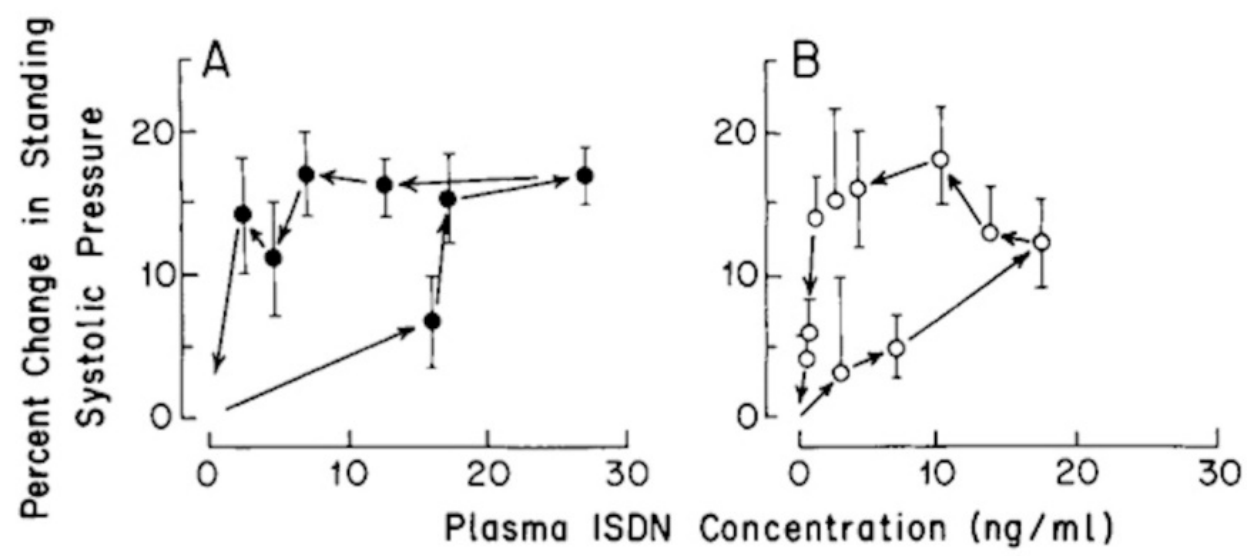

Figure 5. Relationship between plasma ISDN concentration and response after intravenous (•) and sublingual (०) dosing. Reprinted by permission from Macmillan Publishers Ltd: Clinical pharmacology and therapeutics, [44], copyright 1983.

The proposed mechanism for this hysteresis was a delay in distribution to the active site in tissue, a delay in saturation at the receptor level because it is a non-instantaneous event, or contribution of vasoactive metabolites $[109,110]$ which are less active than parent drug [44]. However, the main factor responsible appears to be the delay in equilibrium between the plasma and the site of action [44].

\section{Slow Receptor Kinetics}

Drug receptor theory states that as drug concentration increases the occupancy of the receptor will increase rapidly at first but then it will progressively decrease as the receptors become occupied, and that the drug concentrations necessary to achieve maximal effect $\left(E_{\max }\right)$ can be many fold higher than that necessary to produce a $50 \%$ response. [5]. However, not all drug receptor interactions can be described by an $\mathrm{E}_{\max }$ model since there are limitations in the type of binding, regulation, type of receptors, and the use of surrogate sample-feasible biological matrices (i.e. blood) instead of the actual receptor binding site [5]. However, besides the limited access of drugs to the site of action the presence of slow receptor kinetics are recognized as one of the main causes of counter-clockwise hysteresis [111]. It has been reported that in the case of anti-psychotic drugs they need to traverse not only the BBB but also the transporters that reside in this barrier [12]. The rate at which drugs bind to the receptor $\left(\mathrm{k}_{\mathrm{on}}\right)$ and the rate at which it dissociates from a receptor ( $\mathrm{k}_{\text {off }}$ ) determine the kinetics of a drug such as in the case of anti-psychotic drugs and their relationship with the dopamine $\mathrm{D}_{2}$ receptor [12]. For these types of drugs the $\mathrm{k}_{\text {on }}$ values show low variability for various drugs, but the $\mathrm{k}_{\text {off }}$ can vary within a 1000 -fold range [112]. This switching movement has been evaluated by positron emission tomography (PET) studies in dopamine receptor occupancy after single oral administration of aripiprazole $(2,5,10$ or $30 \mathrm{mg})$ to healthy subjects, which reported that a high receptor occupancy was present after administration (lower arm of hysteresis), but low receptor occupancy was observed at later time points post-drug administration (upper arm of hysteresis) [12].

In the case of telmisartan, an angiotensin receptor antagonist, counter-clockwise hysteresis was observed between plasma concentration and angiotensin II response after oral administration (20, 40 or $80 \mathrm{mg}$ ) following an angiotensin II challenge [74]. It was determined that the hysteresis could be explained because of the tight binding and subsequent slow dissociation of telmisartan from the receptor $\left(\mathrm{AT}_{1}\right)$ on the vascular smooth muscle cells [74], which was based on the ${ }^{3} \mathrm{H}$-telmisartan binding to rat lung $\mathrm{AT}_{1}$ receptors and slow dissociation $\left(\mathrm{t}_{1 / 2}=5.9 \mathrm{~h}\right)$ from the binding sites [113]. Furthermore, the slow dissociation from the $\mathrm{AT}_{1}$ receptor can also contribute to the antagonism of telmisartan [74, 114]. Similarly, candesartan cilexetil and losartan after oral dosing exhibited counter-clockwise hysteresis after angiotensin II challenge in healthy subjects, and it was reported that candesartan exhibited a slower off-rate from the AT1 receptor than losartan [22]. However, the extent of insurmountable antagonistic activity [115117] or differences in distributional phenomena could also occur. The slow onset of the inhibitory 
effect on blood pressure for candesartan [23,118119] could result in a longer than expected PD effect based on the plasma concentrations [22]. On the contrary, in the case of irbesartan the pharmacological effects in the renin-angiotensin system (RAS) are related to the blockade of $\mathrm{AT}_{1}$ receptors by increasing the plasma angiotensin II and plasma renin activity for which an actual clockwise hysteresis was reported [92]. It was reported that the duration of the antagonism of AT1 receptor for irbesartan would be longer than predicted using plasma concentrations [92] as demonstrated after single $150 \mathrm{mg}$ PO for which the antagonism lasted for 2 days, which was much longer than valsartan and losartan [120].

\section{Delayed or Modified Activity}

The pharmacological response of a drug is not only bound by the rate of binding to a specific receptor, but can also be related to a progressive series of stochastic events that could cause a modification or delay in pharmacological activity. [63]. For both regular and neutral protamine Hagedorn $(\mathrm{NPH})$ insulin after a single subcutaneous injection of $10 \mathrm{U}$ or $25 \mathrm{U}$, the time to reach maximum infusion rate of glucose infusion $\left(\mathrm{R}_{\max }\right)$, namely $\mathrm{TR}_{\max }$, occurs at a later time than $t_{\max }$ indicating a delay between maximum serum concentrations and the maximum PD effect. This delay was more obvious for regular insulin, and when the serum concentrations were correlated with glucose infusion rate (GIR) values, a counter-clockwise hysteresis loop was observed for both types of insulin. As the difference in delay between regular and NHP insulin is appreciable, the hysteresis loop was greater for regular insulin than $\mathrm{NPH}$ insulin [63].

In the case of molsidomine [a prodrug for the formation of nitric oxide (NO)] it first requires biotransformation (rapid hydrolysis) to its active metabolite SIN-1, which downstream will release NO [56]. It is because of this metabolic delay in the formation of NO from SIN-1 that counter-clockwise hysteresis has been reported in the change of diastolic diameter after a single oral dose $(4 \mathrm{mg})$ of molsidomine to coronary artery disease (CAD) patients [121]. These findings correlated with a separate study in which finger pulse curve as a PD effect exhibited counter-clockwise hysteresis after administration of molsidomine $(8 \mathrm{mg})$ to healthy subjects [122].

\section{Active Agonist Metabolite}

As the existence of first pass metabolism occurs predominantly in the liver, the route of administration may play a critical role in the appearance of a hysteresis loop. Hysteresis is possible because a drug can be converted to an active metabolite that has a $\mathrm{C}_{\max }$ and a combined peak activity at a later time point compared to the parent drug [5]. For instance, midazolam exhibited a slower reaction time when administered orally compared to intravenous administration, and when the concentrations were combined (both oral and intravenous routes) a counter-clockwise hysteresis loop was evident. However, when the active metabolite $\alpha$-hydroxy midazolam was analyzed, their combined concentrations gave similar reaction times regardless of the route of administration [123].

Itraconazole (ITZ) is a chiral oral active triazole anti-fungal agent that has non-linear PK in rats and humans and dose-dependent first pass metabolism [124-127], and it is also metabolized by CYP3A to the major chiral metabolite hydroxyitraconazole (OH-ITZ) that has similar anti-fungal activity compared to ITZ $[125,128]$. Counter-clockwise hysteresis was observed between the ITZ and $\mathrm{OH}-$ ITZ concentrations entering the liver (expressed as an average of portal venous and aortic concentrations, assuming that the liver receives $25 \%$ of total blood flow via the hepatic artery and $75 \%$ via the portal vein) after duodenal infusion of ITZ ( 5 or $40 \mathrm{mg} / \mathrm{kg}$ ) to chronically catheterized rats [46]. Once the change in hepatic availability $\left(\mathrm{F}_{\mathrm{H}}\right)$ versus ITZ concentrations were plotted over time, a counter-clockwise hysteresis loop was observed indicating an equilibration delay between ITZ and effect $\left(\mathrm{F}_{\mathrm{H}}\right)$ or another factor that would control $\mathrm{F}_{\mathrm{H}}$ such as the production of an active metabolite. The importance of metabolism was evident because of the lack of hysteresis and only a direct hyperbolic relationship between $\mathrm{F}_{\mathrm{H}}$ and OH-ITZ. This lack of hysteresis indicates that this metabolite or some other factor with a similar time course would be the key regulator of CYP3A inhibition and the hepatic availability $\left(\mathrm{F}_{\mathrm{H}}\right)$ of ITZ. Similar relationships were obtained at the $40 \mathrm{mg} / \mathrm{kg}$ dose [46]. However, although analytical assays were capable of measuring the parent compound and its metabolite, no stereospecific analysis was undertaken to delineate the importance of chirality of this racemic drug and the influence of stereoselective metabolism, which should be considered in the 
interpretation of the mechanism underlying the hysteresis loop.

The cholinesterase inhibitor eptastigmine was administered to healthy volunteers as a single oral dose $(10,20$ or $30 \mathrm{mg})$, and counter-clockwise hysteresis was observed between plasma eptastigmine concentrations and both red blood cell acetyl-cholinesterase inhibition and plasma butyrylcholinesterase inhibition [32]. It was evident that eptastigmine is more effective and provides a longer duration in inhibition of cholinesterase in RBC (acetyl-cholinesterase) than in plasma (butyrylcholinesterase), which is similar to previous reports in young [129,130] and elderly subjects [131]. However, these previous findings do not correlate with in vitro studies in which it has been reported that eptastigmine is more active on butyrylcholinesterase compared to acetyl-cholinesterase [132], which could be attributed to the formation of active metabolites such as 3'- and 5'-carboxylic acid derivatives and 3'-carboxylic acid-1-demethyl derivative [133]. Thus, the therapeutic drug monitoring should not be performed using the unchanged eptastigmine concentrations [32]. Furthermore, the observed counter-clockwise hysteresis in RBCs indicates that eptastigmine does not develop acute tolerance, which could be explained by the formation of active metabolites but also because eptastigmine slowly dissociates from acetyl-cholinesterase in RBCs [134]. The observed invertible character of the hysteresis loop in plasma butyryl-cholinesterase inhibition $\mathrm{s}$ suggests that eptastigmine reaches immediate equilibrium with the enzyme [32].

Furthermore, as presented by Gupta et al. [8] the potency of parent compound and the agonistic metabolite (MA) was estimated using generated plasma concentration-time and plasma concentration-effect curves. The degree of counterclockwise hysteresis increases as the agonistic metabolite accumulates [as elimination rate of the metabolite $\left(\mathrm{k}_{\mathrm{mo}}\right)$ decreases and is not formation rate limited]. Furthermore, the degree of hysteresis is also reflective of the potency of the parent compound and agonist metabolite $\mathrm{M}_{\mathrm{A}}$ since as the ratio of potency parent compound/agonist metabolite decreases in magnitude (potency of agonist metabolite increases), the degree of hysteresis will increase.
Indirect Physiological Response

Often drugs act via an indirect mechanism of action and the pharmacologic effect takes considerable time to become evident as concentrations of drug are decreasing. Response is governed by the stimulation or inhibition of factors which can modulate the response [320]. There are two indirect situations following drug administration where the response measured when related to drug concentrations will produce a counter-clockwise hysteresis. Counter-clockwise hysteresis occurs when input is stimulated (i.e. stimulating the release of an endogenous physiological factor) or the output is inhibited (inhibiting or degrading the release of an endogenous physiological factor). For example stimulation of insulin or prolactin leads to a counter-clockwise hysteresis and the inhibition of anticholinesterase or diuresis leads to a counterclockwise hysteresis [321-330] Terbutaline is a bronchodilator that increases cyclic AMP this in turn leads to bronchial smooth muscle dilation. Pyridostigmine and other agents inhibit cholinesterase preserving acetylcholine leading to an increase in muscular activity leading to a gain in muscular response. An indirect response can result in counter-clockwise hysteresis [321-323].

\section{CLOCKWISE HYSTERESIS}

A clockwise hysteresis loop may signify a decreasing pharmacological effect compared with earlier temporal pharmacological effects obtained with the same drug concentration. There are a variety of examples in the literature that suggest this type of pharmacokinetic/ pharmacodynamic relationship as reported in Table 3 [80-102, 313317, and 330]. A clockwise hysteresis may mechanistically manifest due to a variety of underlying mechanisms as discussed below.

\section{Venous vs Arterial Blood Concentrations.}

Drug concentration is often measured in venous blood sampling sites and the site of effect equilibrates with arterial concentrations at different rates. When the effect site (i.e. the brain or heart, etc.) concentration at the receptor site (leading to drug effect) equilibrates faster with arterial concentration than forearm venous blood concentration, clockwise hysteresis may occur. 

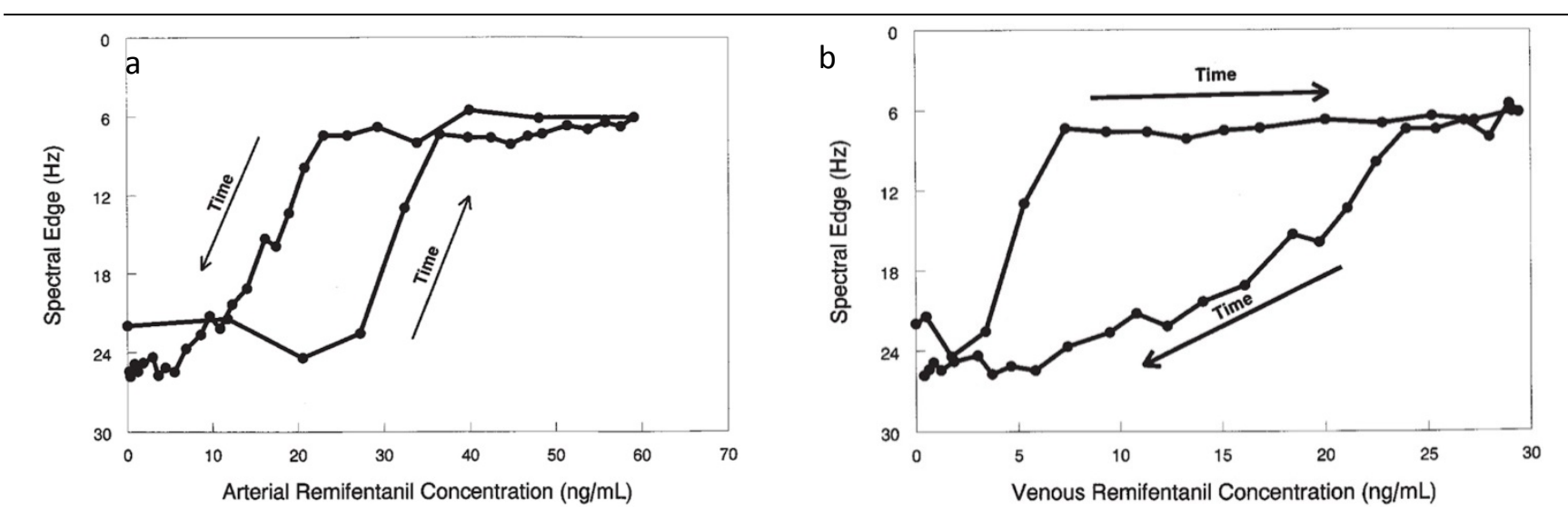

Figure 6. (a) Opioid effect plotted against arterial remifentanil concentration from a representative subject (subject 12). Note the counter-clockwise direction of the hysteresis loop. (b) Opioid effect plotted against venous remifentanil concentration from a representative subject (subject 12). Note the clockwise direction of the hysteresis loop. Reprinted by permission from Macmillan Publishers Ltd: Clinical pharmacology and therapeutics, [69], copyright 1999.

In the case of the opioid remifentanil after IV infusion ( $3 \mu \mathrm{g} / \mathrm{kg} / \mathrm{min}$ for $10 \mathrm{~min})$, it was observed that as opioid concentration increases the spectral edge decreases in the form of counter-clockwise hysteresis as a result of an equilibrium delay between arterial remifentanil concentration and the site of action (brain) (Figure 6a) [69] . However, a significant difference in arteriovenous concentrations in healthy subjects was reported and the direction of the hysteresis loop was reversed in venous drug concentrations (Figure 6b) and it was determined that the venous concentration lag behind the drug effect (clockwise hysteresis) [69]. It was suggested that the arterial drug concentration and effect site reach equilibration faster than the equilibration between arterial and venous concentration $[69,103-106]$.

\section{Tolerance (Down Regulation of Receptors)}

Tolerance is a time-dependent loss of intrinsic activity that can occur within the time course of a single dose, and is called acute tolerance or tachyphylaxis. In the case of pharmacodynamic tolerance intrinsic responsivity of the receptor diminishes over time. Many drugs present clockwise hysteresis due to tolerance because they present a reduced pharmacological effect at the same concentration than earlier leading to an increased effect [140-145]. After oral administration of the benzodiazepine diazepam $(0.28 \mathrm{mg} / \mathrm{kg})$ clockwise hysteresis was observed between tracking or digit-symbol substitution impairment and unbound diazepam concentrations relative to receptor occupancy [85]. Acute tolerance to the psychomotor effects of other benzodiazepines like alprazolam [146,147], midazolam [148], and triazolam [149] has been reported. However, it needs to be acknowledged that the actual mechanism of tolerance development to benzodiazepines is poorly understood [81]. There is no consensus delineating the actual mechanism but there are reports that consider that a decrease in binding potential and/or decrease in receptor functionality could explain the appearance of tolerance [150]. However, other mechanisms such as desensitization associated with receptor phosphorylation, uncoupling, and protein internalization or degradation have been proposed [151].

In the case of temazepam ( $30 \mathrm{mg}$ oral dose), clockwise hysteresis was observed between plasma concentration and sedation score with or without the co-administration of aluminum hydroxide gel (30 $\mathrm{mL}$ ) in end-stage renal patients (Figure 7) [101]. The hysteresis loops were very similar with or without the co-administration of aluminum hydroxide gel, but the main difference was the presence of the lag time of $1 \mathrm{~h}$ when temazepam was administered alone, but it was concluded that aluminum hydroxide gel had no effect on the absorption of temazepam [101]. The clockwise hysteresis was attributed to tolerance [152], which could be a consequence because of a discrepancy between its effective $t_{1 / 2}$ and receptor binding affinity [153]; however, psychological adaptation [154] and functional disturbance [155] can also play a role since sedation has some subjectivity in 
scoring, as a patient can force themselves to stay awake after an entire morning of sleep or the opposite may occur [101].

Interestingly, when temazepam is administered as a racemate a clockwise hysteresis is evident in its sedation. It is likely that stereospecific pharmacokinetics and pharmacodynamics contribute to this relationship [9-10]. Use of a nonstereospecific assay for a chiral drug could lead to an apparent clockwise hysteresis loop where this relationship might not be apparent if the stereospecific concentrations were measured.

In the case of morphine after intragastric administration as a single dose $(15 \mathrm{mg} / \mathrm{kg})$ to rats, it was observed that clockwise hysteresis was evident between unconjugated and conjugated morphine concentrations and anti-thermal pain effect. It was proposed that the fast and short-lasting anti-thermal pain effect of unconjugated and conjugated morphine was due to tolerance [59]. Morphine administered as an IV bolus to rats caused less tolerance than IV infusions at two different rates, with tolerance stronger for the higher infusion rate [156]. Similarly when morphine was administered SC $(14 \mu \mathrm{mol} / \mathrm{kg})$ to rats tolerance (clockwise hysteresis) developed between antinociceptive activity and morphine brain concentrations in renal failure-induced rats, which has been suggested to most likely involve a post-opioid receptor transduction mechanism [58, 157].

In the case of diltiazem after a single oral dose $(120 \mathrm{mg})$ to healthy subjects, clockwise hysteresis was observed in 4 out of 6 subjects (Figure 8) [86]. Significant effects on arteriovascular (AV)

\section{TEMAZEPAM}

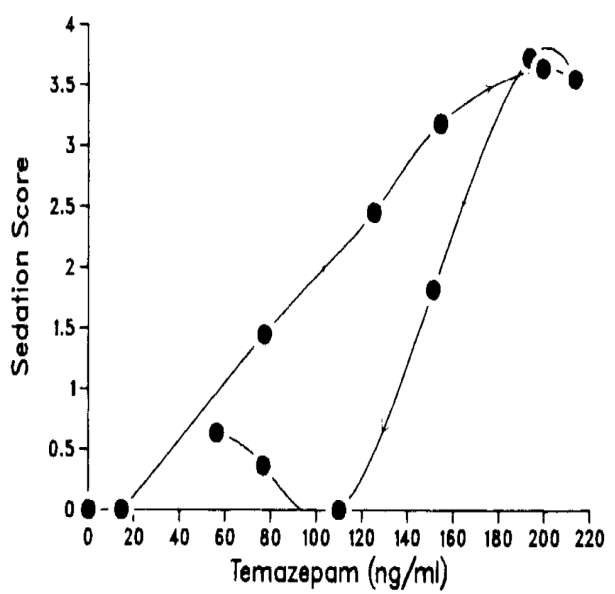

conduction were observed as expressed by the prolongation of PR interval, and because of the inverse relationship between PR interval and heart rate [158] diltiazem would decrease the heart rate in order to increase the PR interval [86]. Furthermore, acute tolerance has been reported for diltiazem after a single oral dose $(180 \mathrm{mg})$ of sustained-release formulations to healthy subjects based on the observed clockwise hysteresis for PQ and PR interval prolongation [87]. However, previous reports indicated counter-clockwise hysteresis after a single IV administration of diltiazem [159-162], which could occur because a delay before equilibrium is reached between systemic and site of action concentrations, or the contribution of active metabolites [163]. But also because tolerance [164], arteriovenous differences during sampling $[69,165$, $166]$, or the presence of inhibitory metabolites with increasing metabolite-to-parent concentration ratio [164]. The arteriovenous equilibrium differences would result in time-dependence over short time intervals, but hysteresis occurred over an extended interval of many hours [86]. The metabolites Ndesmethyldiltiazem and desacetyldiltiazem [167169 ] are produced and have been reported to have equal or lower hemodynamic effects than parent drug $[170,171]$; however, it is unknown how active the unbound metabolites compete/react with the receptor active sites in contrast with diltiazem [86]. The proposed tolerance of diltiazem is not caused by compensating physiological mechanisms because a decrease in blood pressure would indirectly increase the heart rate; however, this does not appear to be evident [86].

\section{TEMAZEPAM + ALUMINUM HYDROXIDE GEL}

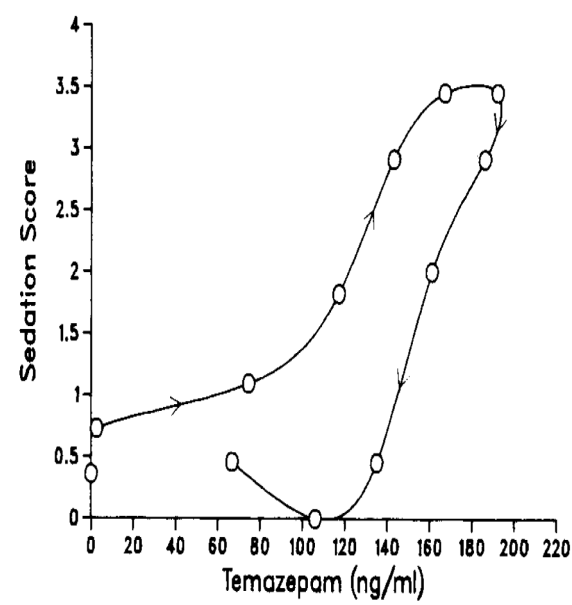

Figure 7. Relationship between mean plasma temazepam concentrations and the NRSS after TM (•) and TM + AHG (०). Reprinted by permission from Macmillan Publishers Ltd: Clinical pharmacology and therapeutics, [101], copyright 1985. 

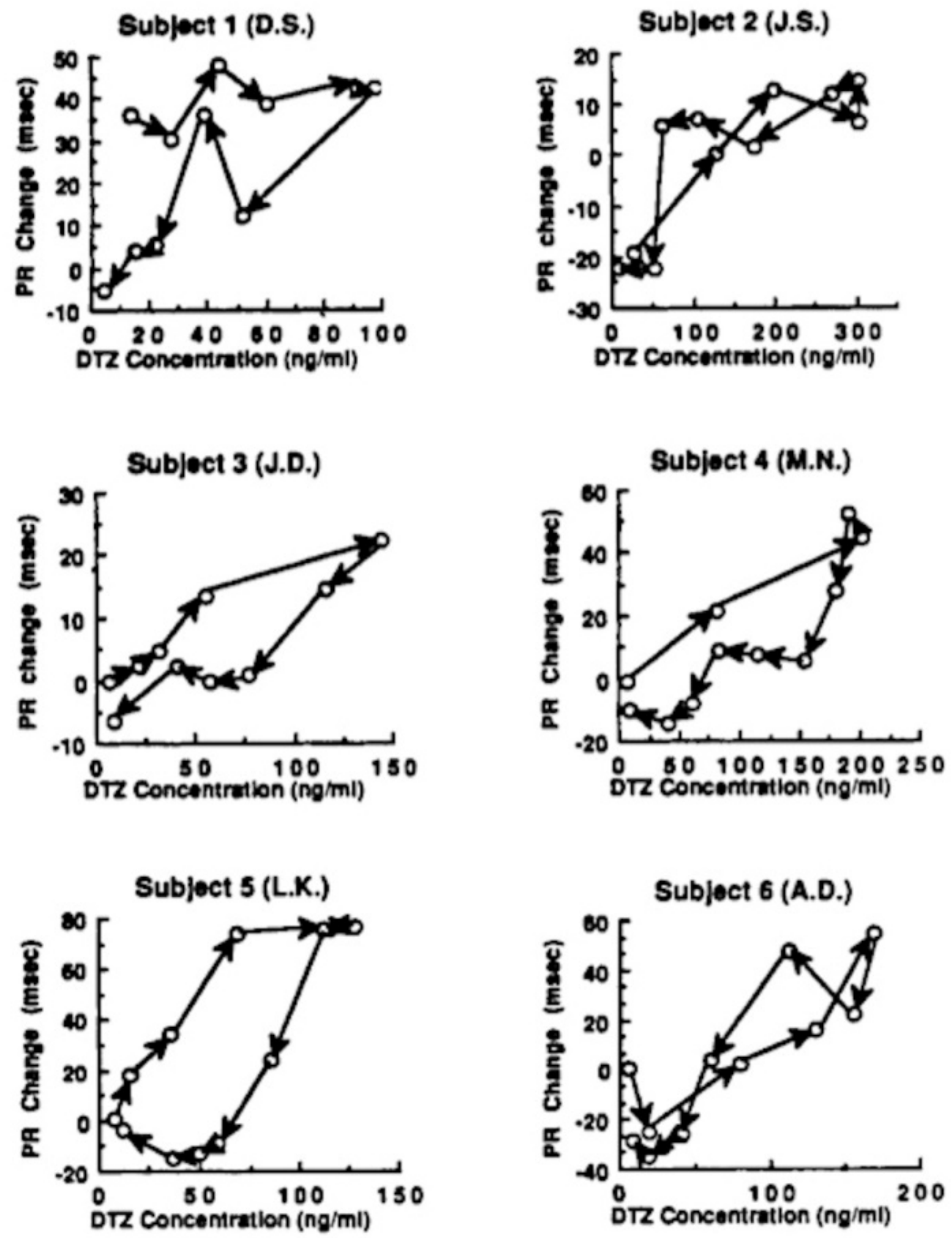

Figure 8. Plots of change in PR interval versus concentration of diltiazem for each of the six subjects over 24 hours. The direction of the arrows indicates the chronologic order of the concentrations. Reprinted by permission from Macmillan Publishers Ltd: Clinical pharmacology and therapeutics, [86], copyright 1989.

\section{Feedback Regulation}

Mammalian physiology has multiple feedback mechanisms to control various pathophysiological processes such as biochemical, nerve and enzymatic functions [5]. In the case of clockwise hysteresis these negative feedback mechanisms decrease the activity for the same concentration. For instance, when almitrine bismesylate (a respiratory stimulant) was infused $(0.5 \mathrm{mg} / \mathrm{kg})$ over 30 minutes to phase II chronic obstructive lung disease (COLD) patients, it was observed that almitrine concentrations increased to a plateau around $500 \mathrm{ng} / \mathrm{mL}$ at 30 minutes but rapidly decreased after the infusion was over. Furthermore, oxygen levels $\left(\mathrm{PaO}_{2}\right)$ reached a maximum around 15 minutes and rapidly declined exhibiting a clockwise hysteresis loop [172]. It has 
also been reported that in the case of almitrine, the production of a feedback mechanism would be present at higher concentrations than $500 \mathrm{ng} / \mathrm{mL}$ [173]. Furthermore, the formation of almitrine inhibitory metabolites has also been proposed as a mechanism, but these have been isolated and synthesized and reported to have poor uptake by the carotid body and have little activity in rats [174]. However, studies in cats have reported that almitrine stimulates the carotid body under the feedback mechanism of the automatic sympathetic ganglioglomerular nerve (GGN) and on a lesser intensity by the contralateral carotid nerve $(\mathrm{CCN})$ [175].

\section{Active Antagonistic Metabolite}

The occurrence of antagonistic metabolites is rare in the pharmacokinetic-pharmacodynamic literature. Typically metabolite concentrations are lower than parent drug in humans, and generally metabolites are more polar and less active than parent and may go unnoticed. However, if an antagonistic metabolite is present and with sufficient potency, the parent drug would appear to be less effective and could have a shorter activity [5]. This has been reported for oxyphenylbutazone affecting the elimination of phenylbutazone [176], 5-hydroxypentobarbital and pentobarbital [177], and hydroxydiphenylhydantoin and hydantoin [178]. Clearly, the greater the potency of the antagonistic metabolite relative to the parent compound, and the slower the elimination rate constant relative to the parent drug, the larger the hysteresis loop [8].

\section{Indirect Physiological Response}

Often drugs act in an indirect mechanism of action and the pharmacologic effect takes considerable time to become evident and response is governed by the stimulation or inhibition of factors that modulate the response [320]. There are two situations following drug administration where the response measured when related to drug concentrations will produce a clockwise hysteresis. Clockwise hysteresis occurs when input is inhibited or the output is stimulated. For example, acid secretion is inhibited by $\mathrm{H}_{2}$-receptor antagonists, and the formation of angiotensin II is inhibited by angiotensin converting enzyme inhibitors and certain anticoagulants such as warfarin that inhibit prothrombin complex activity, methylprednisone and other corticoids that inhibit cortisol. Similarly, diuretics such as furosemide may stimulate secretion of electrolytes into urine, and warfarin inhibits coagulation through prothrombin complex activity. In these situations we would readily expect the appearance of clockwise hysteresis if an effect versus concentration relationship is plotted [321323].

\section{INPUT RATE: PHARMACEUTICAL FORMULATION EFFECTS AND THE DIRECTION OF HYSTERESIS LOOPS}

As various formulation efforts are designed to provide a desired therapeutic profile, variations in pharmacokinetics and pharmacodynamics are common. Thus, by altering the formulation in which a drug is prepared and thereby altering its input rate may also affect the direction of the hysteresis loop at various steps in the process (Figures 2 and 3). For instance, the loop diuretic bumetanide $(1 \mathrm{mg})$ was administered orally to healthy subjects as tablets and as retarded capsules (containing sustained release granules) [20]. In the case of the tablet formulation a counter-clockwise hysteresis was present and it was determined that this was caused due to the time lag between plasma concentration and diuretic effect because bumetanide acts directly in the renal tubule or because of variations in absorption rate from the GI tract [20]. However, in the case of the bumetanide retarded capsules a clockwise hysteresis was evident in the relationship between urinary excretion rate and urine flow rate. In this case the urine flow rate maximum was achieved before the plasma $\mathrm{C}_{\max }$ or maximum of urinary excretion in the case of bumetanide [20]. Similar results were obtained with furosemide (another loop diuretic) for which minimal counterclockwise hysteresis was observed for plain tablets (Furix ${ }^{\circledR}$ ) while controlled release formulations (Furix Retard ${ }^{\circledR}$ and Lasix Retard $\AA$ ) exhibited clear clockwise hysteresis when the diuretic effect versus furosemide excretion rate were correlated [38]. The occurrence of the counter-clockwise hysteresis indicated that after the administration of the plain tablet there was a minimal delay of the effect related to furosemide excretion rate. However, in the case of the clockwise hysteresis of the two controlled release formulations, tolerance and upregulation of the biosignal of the $\mathrm{Na}-\mathrm{Cl}-\mathrm{K}$ transporter protein may be the main mechanism of action responsible for the effect [38]. These results were parallel to the ones observed in a similar study where a regular tablet and a retarded furosemide capsules were administered to healthy subjects [39]. 
Therefore, the higher diuretic effect (related to the amount of excreted furosemide) could have been the result of the slower output of drug from the controlled release formulations compared to the plain tablet, indicating that the diuretic response is independent of intrinsic activity and maximum response [135].

Another relevant example includes lisdexamphetamine mesylate (prodrug that gets metabolized to D-amphetamine and L-lysine) and immediate-release (IR) D-amphetamine when it was administered intraperitoneally (IP) to rats at equivalent doses $(1.5 \mathrm{mg} / \mathrm{kg} \mathrm{D}$-amphetamine base) [28]. Counter-clockwise hysteresis between Damphetamine (from lisdexamfetamine and IR Damphetamine) plasma concentrations and striatal dopamine efflux was evident [28]. The counterclockwise hysteresis was evident because the magnitude of the increase in extracellular dopamine was greater when the concentrations of Damphetamine were decreasing instead of increasing. When the D-amphetamine plasma concentrations were related with the locomotor activity, it was observed that lisdexamfetamine (1.5 or $5.0 \mathrm{mg} / \mathrm{kg}$ IP) presented counter-clockwise hysteresis, whereas there was no hysteresis for IR D-amphetamine, demonstrating the important effect of formulation in the PK-PD relationship. Hysteresis was also analyzed between the striatal extraneuronal dopamine concentration and locomotor activity [28]. In this case counter-clockwise hysteresis was evident for lisdexamphetamine; however, in the case of IR D-amphetamine clockwise hysteresis was observed because there was a greater locomotor response during the ascending portion of the dopamine concentration profile [28].

The observed differences in pharmacokinetics and hysteresis between lisdexamphetamine and IR D-amphetamine could be explained because the prodrug lisdexamphetamine is hydrolyzed by red blood cells and by a rate-limited enzymatic reaction to D-amphetamine [136]. This would cause a more sustained gradual release of D-amphetamine compared to the IR formulation causing a more prolonged and sustained efficacy [137-139]. The counter-clockwise hysteresis observed was linked with the requirement of D-amphetamine to cross the blood-brain barrier in order to enter the striatal nerve terminals before releasing dopamine to produce locomotor activity (functional outcome) [28]. Therefore, lisdexamphetamine would be a lesser stimulant than an equivalent dose of IR Damphetamine. However, lisdexamphetamine offers a later, more gradual and more sustained increase of striatal dopamine compared to a rapid achieving but rapidly declining effect for IR D-amphetamine [28].

The calcium sensitizer levosimendan when administered as a single dose via different routes: IV infusion ( $2 \mathrm{mg}$ for $5 \mathrm{~min}$ ), slow-release tablet (SR, $2 \mathrm{mg}$ ), conventional tablet (CT, $2 \mathrm{mg}$ ) or conventional capsule (CC, $2 \mathrm{mg}$ ) to healthy humans exhibited counter-clockwise hysteresis in all the formulations for the electromechanical systole corrected for heart rate (QS2i) (Figure 9) [49]. It was observed that the SR formulation resulted in lower concentrations and generally weaker effects compared to the other formulations. The observed hysteresis was proposed to occur because of an equilibration delay that reflects the time that the drug is required to distribute from the plasma to its site of action (heart) and the difference between formulations may be due to the physiological barriers and physicochemical properties of the actual formulations that would render different absorption and distribution profiles [49]. Furthermore, counter-clockwise hysteresis in QS2i has also been reported in severe congestive heart failure patients after IV infusion $(0.2 \mu \mathrm{g} / \mathrm{kg} / \mathrm{min}$ for 6 hours) or oral dose (2 mg), for which also the fact that levosimendan has inotropic and vasodilatory effects could contribute to development of hysteresis [48]. It is evident that in all cases the later effect is higher at $0 \mathrm{ng} / \mathrm{mL}$ than before the study commenced. These is exactly what would be predicted if you have a specific assay for the parent drug and have an active metabolite that is not detected or accounted for. More recent literature has demonstrated that levosimendan has two active metabolites OR-1896 and OR-1855 that have mean elimination half-lives of 72.6 and 81.3 hours, respectively, compared to the elimination half-life of parent drug that ranges between 1.1 to 1.4 hours [324].

\section{Theoretical and Practical Considerations: Clockwise and Counter-clockwise Hysteresis and the Importance of Specific Measurement of Concentration}

Total (drug concentration + metabolites) together can be measured by a non-specific analytical assay method. 


\section{$\triangle$ QS2i}
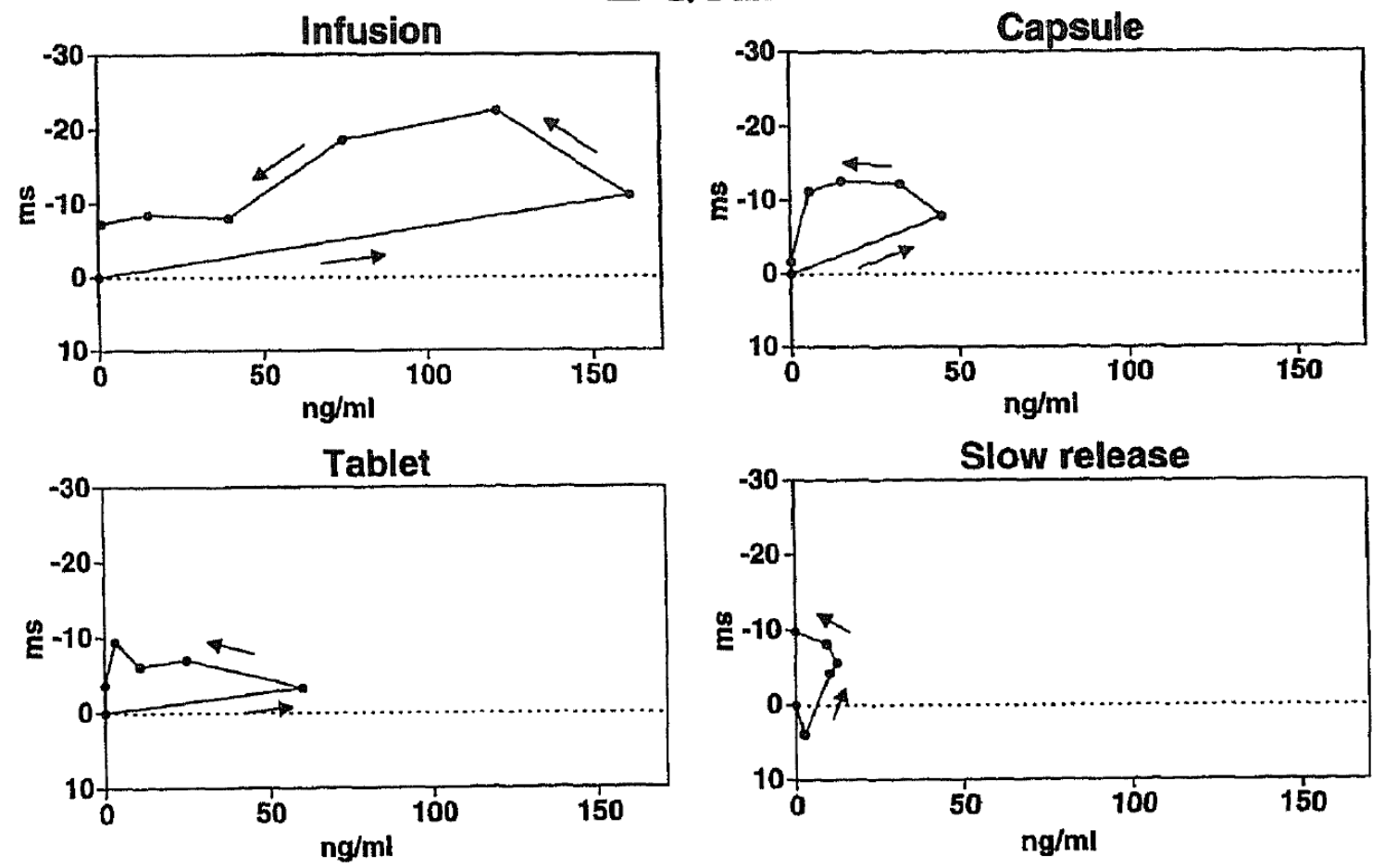

Figure 9. The concentration-effect loops for QS2i after single doses of $2 \mathrm{mg}$ of levosimendan as an intravenous ( $\mathrm{n}=10)$ and three different oral formulations $(n=8)$ in healthy subjects. The levosimendan concentrations and corresponding QS2i values are plotted in the graph and the points are connected in time order. Reprinted by permission from Dustri-Verlag: International Journal of Clinical Pharmacology and Therapeutics, [49], copyright 1998.

This would most often occur with the use of a radioimmunoassay, or by measuring radiolabelled drug in early pharmaceutical development. Using non-specific methods of analysis, drug concentration and concentration of metabolite would be measured simultaneously and could be plotted together versus effect. As presented in simulations by Gupta et al. [8] the potency of the parent compound and the generated agonistic metabolite (MA) were estimated using generated plasma concentration-time and plasma concentration-effect curves. Different derived equations were used to describe parent and MA PK, and plasma concentration-effect profiles using PD models in which the effect was considered a linear function of parent and MA (equation 3) [8].

$$
E=P_{P A R} * C+P_{M A} * C_{M A}
$$

where, $P_{\mathrm{PAR}}$ is the pharmacological potency of the parent compound and $\mathrm{P}_{\mathrm{MA}}$ is the pharmacological potency of the metabolite. A competitive agonist $\mathrm{E}_{\max }$ model was developed using equation 4 [8]

$$
E=E_{\max }\left(\frac{C}{E C_{50}} \frac{C_{M A}}{E C_{50 M A}}\right) /\left(1+\left(\frac{C}{E C_{50}}+\frac{C_{M A}}{E C_{50 M A}}\right)\right)
$$

E vs. C plot is in actuality an $\mathrm{E}$ vs. $\mathrm{C}+\mathrm{CMA}$ in these instances (Figure 10). When the parent compound and metabolite are equipotent no hysteresis was observed $\left(\mathrm{PPAR} / \mathrm{PMA}\right.$ ratio $=1$ or $\left.\mathrm{EC}_{50} / \mathrm{EC}_{50} \mathrm{MA}\right)$ (Figure 10a) Clockwise hysteresis was present when $\mathrm{C}>\mathrm{MA}$ in potency (Figure $10 \mathrm{~b}$ ) and counter-clockwise hysteresis was reflective of MA $>\mathrm{C}$ in potency (Figure 10c). Similar findings were demonstrated and applicable using Equation 3. Therefore, the potency of the metabolite relative to parent compound is the key to the hysteresis and its direction, and it needs to be considered that nonspecific analytical assays such as RIA or achiral analytical methods in PK-PD studies could cause interpretational problems but also warrants the need to identify all of the active metabolites or stereoisomeric forms. 

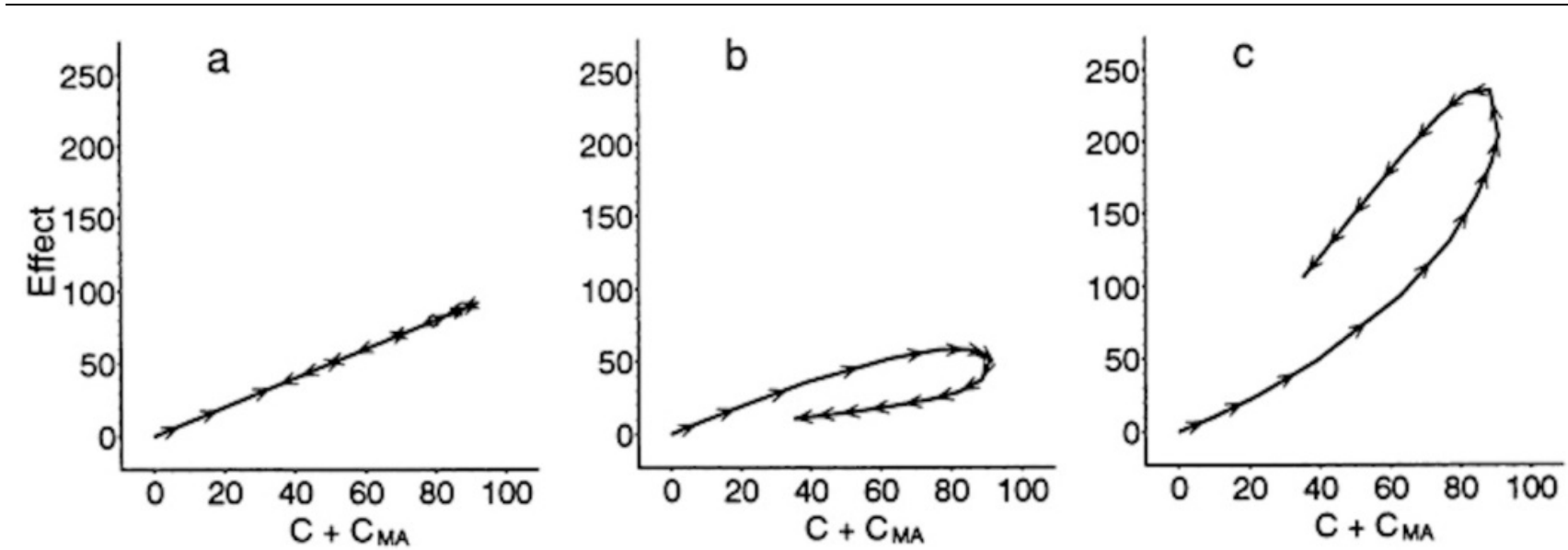

Figure 10. Plot of observed effect $(E)$ vs. unbound plasma concentration $\left(C+C_{M A}\right)$ for parent compound and agonistic metabolite $\left(\mathrm{M}_{\mathrm{A}}\right)$. The pharmacodynamics of parent compound and $\mathrm{M}_{\mathrm{A}}$ are described by a linear model (Equation 3), and where, for $\mathrm{M}_{\mathrm{A}}$ pharmacokinetics, $\mathrm{k}_{\mathrm{mo}}=0.05$ and $\mathrm{P}_{\mathrm{PAR}}=1$ : collapsed hysteresis with $\mathrm{P}_{\mathrm{MA}}=1$ (a), clockwise hysteresis with $\mathrm{P}_{\mathrm{MA}}=0.33$ (b) and counter-clockwise hysteresis with $\mathrm{P}_{\mathrm{MA}}=3$ (c). Reprinted by permission from Springer Science and Business Media: Pharmaceutical Research, [8], copyright 1993.

What is apparent is that if using a non-specific method of analysis (Figure 11b), a direct linear relationship could be interpreted between concentration and effect (Figure 1a, Figure 11b), however employing a specific method of analysis (Figure 11a) demonstrates the existence of a counter-clockwise hysteresis loop. Likewise, a clockwise hysteresis loop could be incorrectly assigned to a situation where a counter-clockwise hysteresis is occurring (Figure 10a and Figure 11a). Finally, a larger counter-clockwise hysteresis may be evident (Figure 10c) than if a specific method of concentration analysis utilized (Figure 11a).
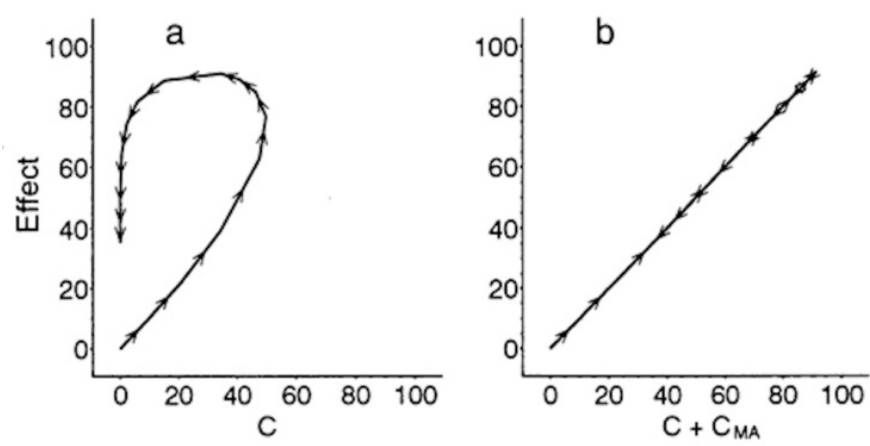

Figure 11. (a) Plot of observed effect (E) vs. unbound plasma concentration for parent compound (C) showing counter-clockwise hysteresis. The pharmacodynamics of parent compound and agonist metabolite $\left(\mathrm{M}_{\mathrm{A}}\right)$ are described by a linear model, with $\mathrm{P}_{\mathrm{PAR}}=\mathrm{P}_{\mathrm{MA}}=1$ and $\mathrm{k}_{\mathrm{mo}}$ $=0.05$. (b) Plot of observed effect (E) vs. unbound plasma concentration $\left(\mathrm{C}+\mathrm{C}_{\mathrm{MA}}\right)$ for parent compound and MA showing collapsed hysteresis, where the pharmacokinetic-pharmacodynamic model is as in a. Reprinted by permission from Springer Science and Business Media: Pharmaceutical Research, [8], copyright 1993.

\section{Time-Dependent Protein Binding}

In a simulation study the time-dependent protein binding can occur as a consequence of a time dependent decrease in protein concentration in serum, by displacement of a metabolite. When pharmacological effect was plotted versus total drug concentration in serum counter-clockwise hysteresis was evident; however, when concentration of free drug in serum, which was correlated with pharmacological effect, was plotted no hysteresis was evident [9]. Time-dependent protein binding that can occur as a consequence of an increase in protein concentration in serum can lead to a decrease in free fraction of drug. When pharmacological effect was plotted versus total drug concentration in serum (i.e. free and bound drug) clockwise hysteresis was evident; however, when concentration of free drug in serum was correlated with pharmacological effect no hysteresis was evident [9]. Despite these theoretical simulations and modeling no examples of studies in the literature demonstrating this phenomenon are apparent to date.

\section{Racemic Drug and Chirality}

The utility of using non-stereoselective assay methodology for measuring concentration of a 
racemic drug can lead to interpretation errors in the concentration versus pharmacological effects correlation and the assignment of a hysteresis loop $[10,179]$. Indeed as stated by Ariens 30 years ago [297] an analytical assay that does not measure the enantiomers of a racemic drug and attempts to relate total concentrations to effect without stereochemical knowledge is "highly sophisticated scientific nonsense". However, many examples from studies in both Tables 2 and 3 continue to produce this achiral scientific gibberish. After oral administration when enantiomers differ substantially in total body clearance and when an active enantiomer has lower clearance, counterclockwise hysteresis was evident between plasma concentration of total drug and its pharmacological effect. The active enantiomer would constitute a greater proportion of the total concentration as time progresses. In addition, when the $\mathrm{V}_{\mathrm{d}}$ of an active enantiomer is larger than the inactive enantiomer and a different half-life of the enantiomers ensues, the proportion of the active enantiomer in the total concentration would be higher over time. In the case of zero-order absorption, which could be possible when enantiomers are orally absorbed and transported via carriers, and when the $K_{a}$ of the active enantiomer is less than that of the inactive enantiomer hysteresis was evident. The implications of chirality on pharmacodynamics modeling were also simulated when enantiomers acted as competitive agonists, partial agonists, competitive agonists, enantiomers may also have affinity and activity and intrinsic activity at separate receptors, separate transduction mechanisms or affinity and intrinsic activity at separate receptors but with a common transduction mechanism. When the more active enantiomer had higher clearance or a smaller volume of distribution plots of pharmacological effect versus non-stereospecific plasma concentration produced anti-clockwise hysteresis loops [179].

When a racemic drug's active enantiomer has a higher total body clearance a clockwise hysteresis describes the relationship between total concentration and pharmacological effect as the active enantiomer would be a lower proportion of the total concentration over time. In addition, when the volume of distribution of active enantiomer is smaller than the inactive enantiomer and a different half-life of the enantiomers ensues, the proportion of the active enantiomer in the total concentration would be lower over time. In the case of zero-order absorption which could be possible when enantiomers are orally absorbed and transported via carriers and when the $K_{a}$ of the active enantiomer is greater than that of the inactive enantiomer hysteresis was evident.

Many studies identifying hysteresis using racemic drugs (i.e. Tables 2 and 3 ) and that have utilized non-stereospecific assays may therefore require further evaluation of their underlying mechanisms. The implications of chirality on pharmacodynamics modeling extended the importance of pharmacodynamics to the hysteresis relationship [179]. There are a variety of possible pharmacological interactions between enantiomers that were evaluated through the use of simulation of the pharmacological effect-time profile and ultimately clockwise hysteresis was also evident. Enantiomers may act as competitive agonists, partial agonists or competitive antagonists. Enantiomers may also have affinity and activity and intrinsic activity at separate receptors, separate transduction mechanisms or affinity and intrinsic activity at separate receptors but with a common transduction mechanism. In cases where the more active enantiomer had higher clearance and a smaller volume of distribution, plots of pharmacological effect versus non-stereospecific plasma concentration produced clockwise hysteresis loops. The plots outlined in Figures 10 and 11 are also applicable to achiral analysis of total enantiomers of a racemate $[8,10,179]$. Depending on both the pharmacokinetic and pharmacodynamic behaviours of the enantiomers, the less active enantiomer may significantly affect the observed effect and therefore the reliability of any hysteresis loop obtained with the use of suspected achiral concentration data. All of the eight different clockwise hysteresis examples that use racemic drugs in Table 3 may be similar to Figure 10b but could in fact produce counter-clockwise hysteresis if stereospecificity was considered in the analysis.

\section{PHARMACOKINETIC- PHARMACODYNAMIC (PK-PD) MODELING} The general assumption is that drug in the surrogate biological matrix, such as plasma, and the drug at the biophase are at equilibrium [5]. However, this assumption may not be correct because the drug concentrations change as a result of the innate pharmacokinetics of the drug, and the pharmacodynamics could also change independently or in an opposite direction to the 
drug concentration. Various approaches for simultaneous PK-PD modeling have been explored [180], including compartmental models [181], system dynamics models [182], distributed log analysis [183], or numerical deconvolution [184]. All of these approaches have advantages and disadvantages due to the complexity of the inherited mathematical equations utilized.[185, 325-326].

\section{Effect Compartment Model}

The most commonly used PK-PD model is the effect compartment model (Figure 12), which assumes that the active site compartment receives a negligible amount of drug and has a negligible volume [4, 164, 186-189].

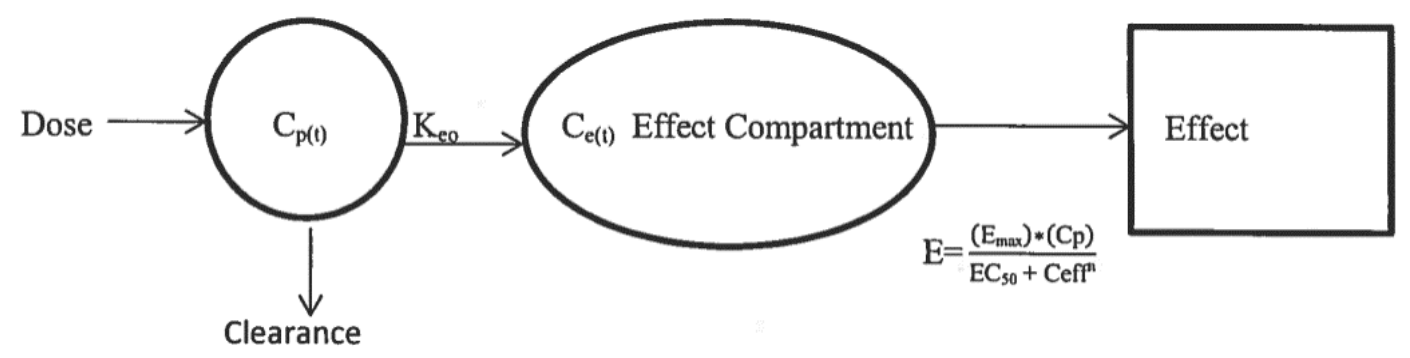

Figure 12. Effect Compartment Model

This approach has now been implemented in various modeling software with the so called nonparametric or parametric link model [190].The use of an effect compartment model has been widely used to collapse the hysteresis loop, which is generally performed by linking it to the PK model as it was originally proposed by Segre [191] and by Galeassi et al. [192], and later elaborated and described by Holford and Sheiner [164] and by Sheiner et al. [3]. The effect compartment model has been described by equation 5 .

$$
\begin{aligned}
& C e=\frac{K A D}{\frac{V d}{F}}\left(\frac{(K 21-K A) e^{-K A t}}{(\alpha-K A)(\beta-K A)(K e O-K A)}+\frac{(K 21-\alpha) e^{-\alpha t}}{(K A-\alpha)(\beta-\alpha)(K e O-\alpha)}+\frac{(K 21-\beta) e^{-\beta t}}{(K A-\beta)(\alpha-\beta)(K e O-\beta)}\right. \\
& \left.+\frac{(K 21-K e O) e^{-K e O t}}{(K A-K e O)(\alpha-k e O)(\beta-K e O)}\right)
\end{aligned}
$$

where, $C_{\mathrm{e}}$ is the effect compartment concentration, $K A$ is the absorption rate constant, $K$ is the elimination rate constant, $K_{21}$ is the transference rate constant from the peripheral to the central compartment, $V_{d} / F$ is the volume of distribution corrected by the bioavailability of the oral dose $D, \alpha$ and $\beta$ are the hybrid rate constants corresponding to the initial and terminal slope factors, respectively, and $K_{e 0}$ is the constant of the disappearance of the effect $[29,164]$.

The main assumption necessary to make the hysteresis loop collapse is that the effect depends on the drug concentration in an effect compartment rather than in the systemic compartment.
Furthermore, the effect is correlated to $C_{\mathrm{e}}$ by the sigmoidal $E_{\max }$ PD model using equation 6 [29].

$$
E=\frac{\left(E_{\max }\right) *\left(C e^{h}\right)}{E C_{50}^{h}+C e^{h}}
$$

where, $E$ is the observed effect, $E_{\max }$ is the theoretical maximal effect that can be attained, $C_{\mathrm{e}}$ is the effect-compartment concentration, $\mathrm{EC}_{50}$ is the $C_{\mathrm{e}}$ value that produces an effect equivalent to $50 \%$ of the theoretical maximal effect and $h$ is a parameter that determines the steepness of the curve. 
The fitting procedures then can be performed using a PK/PD modeling software. The effect compartment model has been applied to the observed counter-clockwise hysteresis between diclofenac blood concentrations and functional index (FI) recovery after oral diclofenac administration to male Wistar rats (Figure 13a) [29]. This hysteresis loop has been previously reported to be due to the formation of active metabolites; however, diclofenac metabolites do not exhibit anti-nociceptive activity [193, 194] and local administration of diclofenac causes an antiinflammatory effect [195]. Another proposed mechanism of action was a cascade of physiological events [196] because the anti-nociceptive effect of diclofenac is an indirect response from the inhibition of prostaglandin synthesis [197]; however, it has been reported that diclofenac has a rapid pharmacodynamic effect when administered locally [195] indicating that once it reaches the site of action it has a rapid pharmacological response

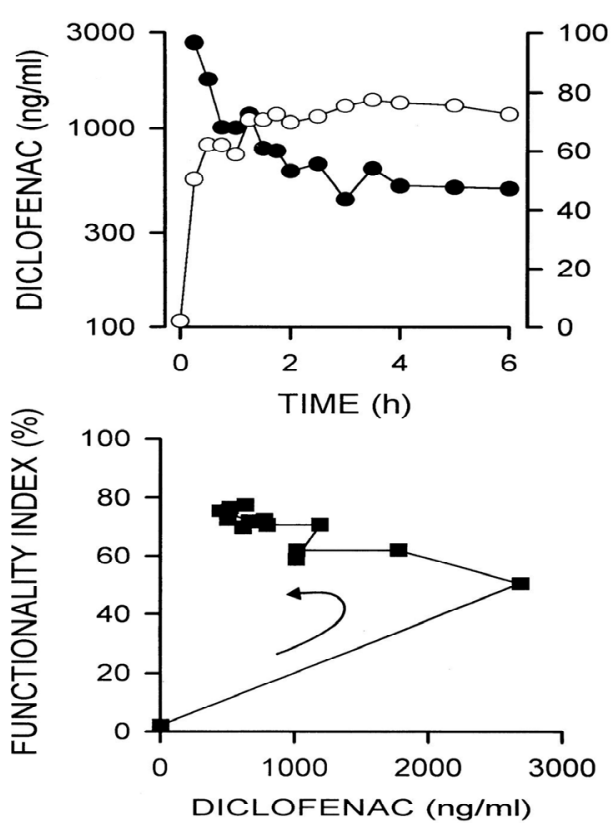

without delay. Therefore, the lag in anti-nociceptive effect onset occurs because there is a slow equilibrium kinetics between blood concentration in the central and effect compartment [29]. The use of the effect compartment model results in the collapse of the hysteresis loop (Figure 13b), because the derived effect data exhibited good fit as a function of the estimated $C_{\mathrm{e}}[29]$.

Tolerance Model: Incorporation of the Hypothetical Non-Competitive Antagonist

A tolerance model was developed by Prochet et al. [199] in which a hypothetical non-competitive antagonist is included to represent the factor driving tolerance (Figure 14), and this has been applied to diltiazem [86], clonidine [25], ephedrine [200], and morphine [41]. This model can describe tolerance based on competitive or non-competitive inhibition of response by down-regulation of receptors or by a metabolite [86].

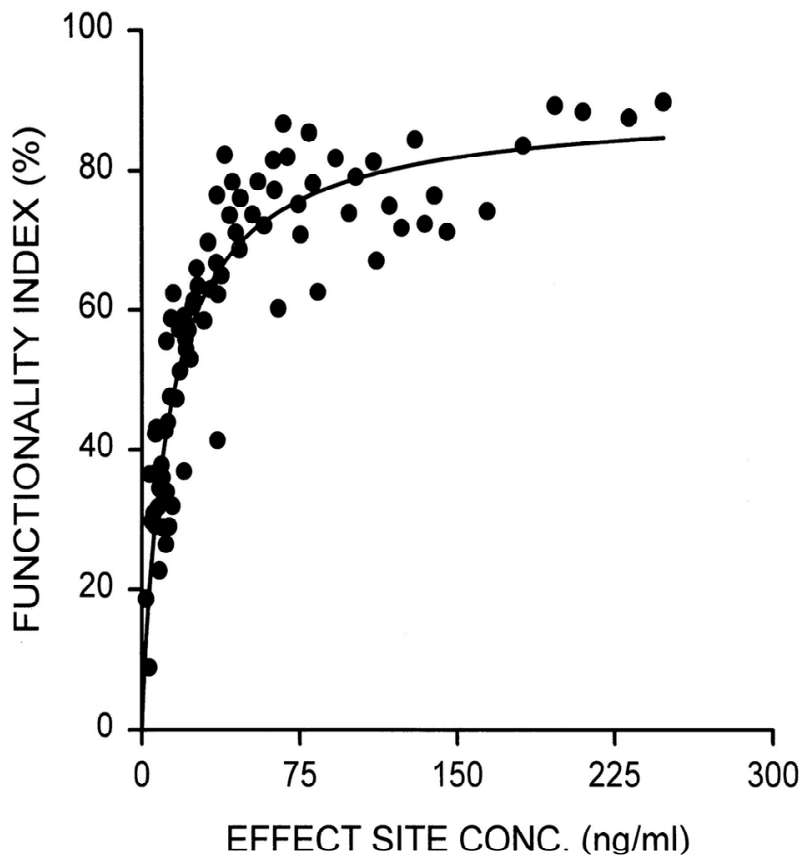

Figure 13. (a) Relationship between the measured blood concentration of diclofenac and the observed anti-nociceptive effect expressed as FI recovery after oral administration of a $10 \mathrm{mg} / \mathrm{kg}$ sodium diclofenac dose to rats that were injected with uric acid in the right hind knee. (b) Relationship between the observed anti-nociceptive effect, measured as FI recovery, and calculated effect-compartment Diclofenac concentrations corresponding to PO administration of $0.56,1,1.8$, $3.2,5.6$ and $10 \mathrm{mg} / \mathrm{kg}$ of sodium diclofenac. Reprinted by permission from American Society for Pharmacology and Experimental Therapeutics: The Journal of pharmacology and experimental therapeutics, [29], copyright 1997. 


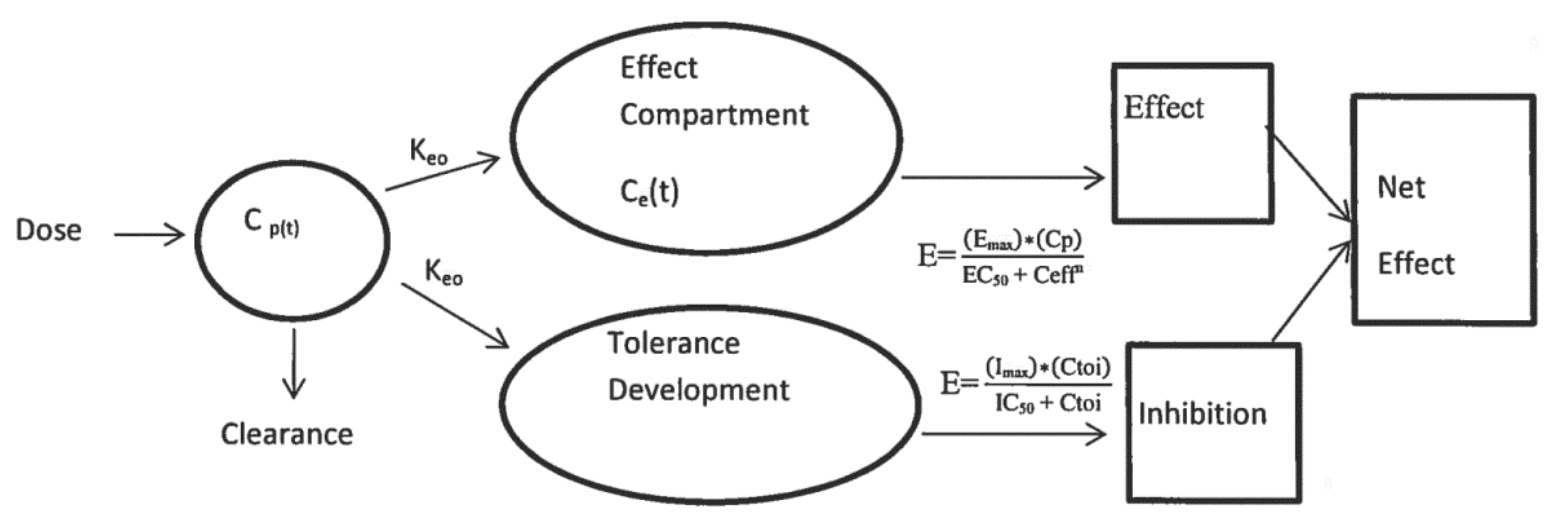

Figure 14. Tolerance Model

where, $\mathrm{E}$ is the measured PR interval, $\mathrm{E}_{0}$ is the baseline $\mathrm{PR}$ interval, $\mathrm{C}$ is the drug plasma concentration, $\mathrm{S}$ is the slope of the linear relationship between effect and concentration in the absence of antagonist, $\mathrm{C}_{\text {ant }}$ is the concentration of the hypothetical antagonist, and $\mathrm{C}_{\text {ant50 }}$ is the concentration of hypothetical antagonist resulting in $50 \%$ inhibition of effect. Hypothetical antagonist concentration units are those of steady-state drug concentrations [86].

In the case diltiazem after a single oral dose $(120 \mathrm{mg})$ to healthy subjects, the same model was not only applied to parent drug but also to the metabolites N-desmethyldiltiazem and desacetyldiltiazem. The best fit of the various options tested was obtained with the incorporation of the hypothetical non-competitive antagonist rather than the use of any of the metabolite concentration (Figure 15) [86]. Panel B is the best fit. The 400- 800 min times demonstrate a lack of weighting.

\section{Indirect Physiological Response Turnover Model.}

As the pharmaceutical industry has diversified from small molecules into administration of proteins and peptides we have seen effects that are more discordant in time and production or degradation of a mediator that is often responsible for drug action. [321-330] As the mechanism of action of many drugs involves protein synthesis, a drug may affect the net response measured by altering either then $\mathrm{K}_{\text {in }}$ or $\mathrm{K}_{\text {out }}$ that will evoke the response measured (Figure 16). Indirect models allow for a later $\mathrm{T}_{\max }$ with larger doses of drug. Of course partial inhibition or synergism can be adapted, circadian variation accounted and cascade models could be developed and transduction effects incorporated into these models. As many xenobiotics act indirectly through physiological and biochemical mediators and enzymes there is broad applicability of this approach. Jusko has pioneered the work in turnover model systems by pointing out that four main mechanisms are involved in stimulating or inhibiting production of the biosignal that is measured as the effect, or inhibiting or stimulating its removal [321-323].These models can be further extended by adding more transit compartments which are similar to steps in the transduction of the progression of the measured effect.

\section{DISCUSSION}

The appearance of hysteresis loops in PK-PD analysis indicates that the relationship between drug concentration and the effect being measured is not direct but has an inherent time delay and disequilibrium. As hysteresis depends on both pharmacokinetics and pharmacodynamics including all the innate factors affecting either of them this has a critical role in the appearance, direction, magnitude and collapse of a hysteresis loop. Some of these factors include the equilibrium / disequilibrium between sampled PK concentration and effect site concentration, rate of pharmacological receptor activation/deactivation, rate of signal transduction at the receptor level, presence of agonist or antagonist active metabolites, upregulation/downregulation of pharmacological response, rate of equilibration between arterial plasma concentrations (compartment delivering drug to effect site) and venous plasma concentrations (sampling compartment for concentration analysis), among others. 


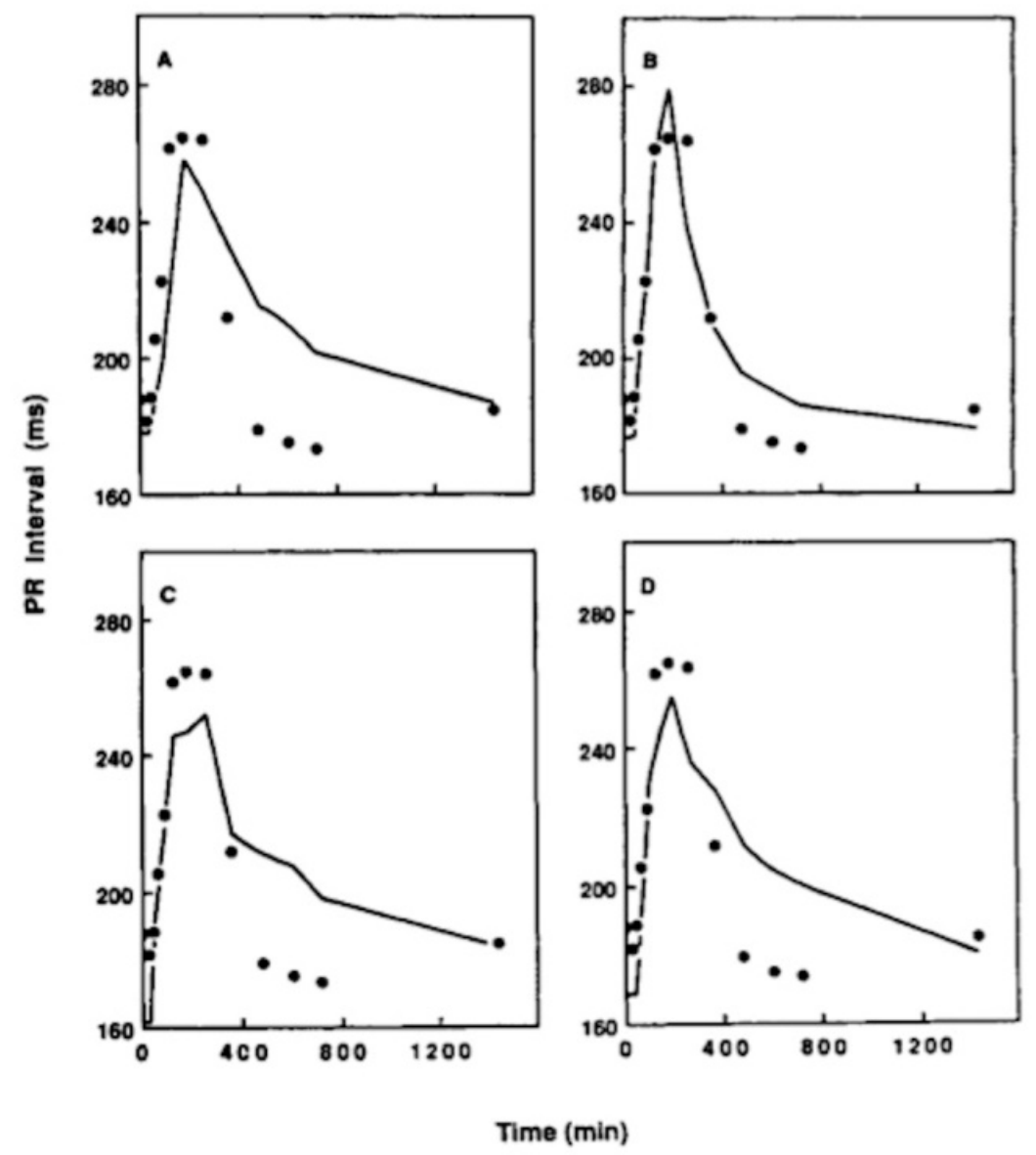

Figure 15. Plots of PR interval versus time for subject 5 showing the results of pharmacodynamic fitting procedures. A, Fit to linear pharmacodynamic model assuming no tolerance. B, Fit to model of acute tolerance that incorporates the effect of a hypothetical antagonist. C, Fit to model of acute tolerance, assuming N-desmethyldiltiazem is an antagonist. D. Fit to model of acute tolerance, assuming desacetyldiltiazem is an antagonist. Reprinted by permission from Macmillan Publishers Ltd: Clinical pharmacology and therapeutics, [86], copyright 1989.

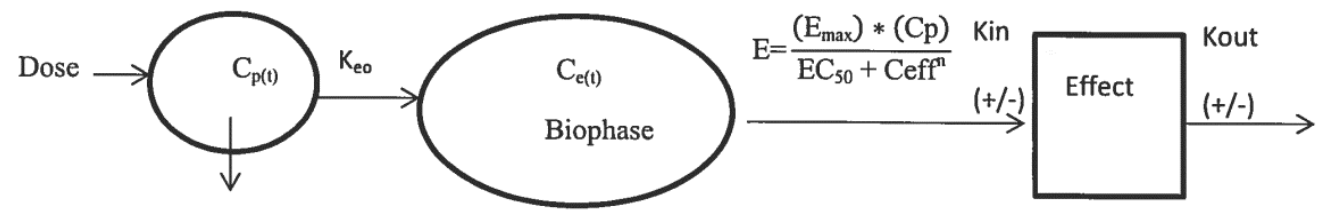

Clearance

Figure 16. Indirect Response Turnover Model

In addition, the study design can play a major role since the availability of a specific analytical method plays a critical role in the ability to detect the pharmacologically relevant analyte (parent vs. metabolite, or racemate vs. enantiomer). Also, it is critical to understand the nature of the activity of a metabolite (namely agonist or antagonist) because generally an agonist metabolite would aid in the development of a counter-clockwise hysteresis, while an antagonist metabolite would do the same for clockwise hysteresis loops.

It can be observed that hysteresis loops are present for a wide range of drugs and the mechanism of action (MOA) sometimes overlap between each other. In the case of clockwise hysteresis the most common MOA is tolerance, 
which is a constant concern in the therapeutic use of benzodiazepines, opioids and CNS drugs. However, tolerance has also been reported for loop diuretics and nitrates. Feedback mechanisms can also play a critical role in hysteresis because they control various physiological processes and it has been reported that they can also decrease the pharmacological effect for the same drug concentrations, which could cause inhibition and/or depletion at the terminal/receptor level [93, 201, 202]. Another factor to consider is drug and effect location and the protective barriers surrounding the active site such as the brain. As the brain possesses a protective blood-brain barrier (BBB) it would be expected that a delay in reaching the site of action would occur. Another factor that may be neglected in PK-PD interpretation is the potential differences in arteriovenous concentrations of a drug, because arterial blood delivers the drug to the effect site and venous blood is typically the sampled matrix. This for instance has been observed for thiopental in which concentrations were higher in the arterial samples during infusion but became comparable to venous samples after the infusion, and at the time of adding the pharmacodynamics component (EEG frequency reduction by spectral edge analysis), it was observed that the hysteresis loop was evident for arterial but not for venous blood [165].

The current ability to measure receptor binding using positron emission tomography (PET) or an equivalent technology can help us understand better the rate at which drugs bind to the receptor $\left(\mathrm{k}_{\mathrm{on}}\right)$ and the rate at which it dissociates from a receptor $\left(\mathrm{k}_{\mathrm{off}}\right)$ to determine the kinetics of drugs such as antipsychotics, in which the $\mathrm{k}_{\text {on }}$ values show low variability, but the $\mathrm{k}_{\text {off }}$ can vary within a 1000 -fold range [112]. This interplay is critical because with the help of PET the dopamine receptor occupancy after single oral administration of aripiprazole was evaluated. It was observed that high receptor occupancy was present after the administration (lower arm of hysteresis) but low receptor occupancy was observed at later time points post drug administration (upper arm of hysteresis) [12].

The relevance of using different pharmaceutical formulations and routes of administrations has been presented to illustrate the need to be considered in order to achieve the desired therapeutic profile. For instance, bumetanide as a tablet exhibited counterclockwise hysteresis because a time lag between plasma concentration and diuretic effect is evident since the drug acts directly in the renal tubule or because of variations in absorption rate from the GI tract. However, in the case of the retarded capsules a clockwise hysteresis was present because the maximum urine flow rate was achieved before the plasma $\mathrm{C}_{\max }$ or before the maximum of urinary excretion [20]. Thus, it can be clearly observed that the pharmaceutical formulation may change the pharmacodynamics of a drug. However, the change from one formulation to another does not follow a constant pattern in the direction of occurrence of a hysteresis loop as this is dependent on the drug itself and the actual effect site. Other drug delivery formulation approaches have centered on the modification of the lipophilicity of a drug and having a closer delivery to the site of action in order to try to circumvent biological barriers. For instance, morphine and fentanyl were formulated into a pressurized olfactory delivery (POD) device. Clockwise hysteresis was observed after POD administration of both morphine and fentanyl, but counter-clockwise hysteresis was observed after nasal drops and IP administration of morphine, while no clear hysteresis after nasal drops and IP administration of fentanyl [57]. These observed differences could be attributed to significant differences in hydrophobicity and ability to penetrate the $\mathrm{BBB}$, which not only affected the systemic plasma concentrations but also the delivery to the nasal olfactory epithelium.

With the relevance that hysteresis loops have, various modeling approached have been proposed to collapse hysteresis and allow for adequate PK and PD estimates, and the most commonly used model remains the effect compartment model, which assumes that the active site compartment receives a negligible amount of drug and has negligible volume [4, 164, 186-189]. However, variation of this model such as the tolerance model has also been implemented [102] where a tolerance (use of a linear PD model) and pseudo-tolerance (use of an effect compartment model) PK-PD model were evaluated for different drugs [104, 105, 203]. Also as proposed by Gupta et al. [8], the potency of the metabolite relative to parent compound is the key to the hysteresis and its direction, and it needs to be considered that non-specific analytical assays such as RIA or achiral analytical methods in PK-PD studies could cause interpretational problems but also warrants the need to identify all of the active metabolites and enantiomers.

Ultimately it can be seen that the presence of a hysteresis loop provides guidance on how to model 
pharmacokinetic-pharmacodynamic relationship of a particular drug, it allows the pharmaceutical scientist to design studies more appropriately when arteriovenous drug versus venous concentration differences are large and to provide a more rational basis for dosage individualization. A very clear example is the case of piritramide, for which it is recommended that it should be initially administered as an intravenous bolus of at least 5 $\mathrm{mg}$ to circumvent its pronounced hysteresis [96].

\section{CONCLUSIONS}

The linking of pharmacokinetics and pharmacodynamics is taking on greater relevance because of the necessity to understand the concentration-time profiles of drugs and the need for the ability to determine dosing regimens that will achieve the necessary concentrations for optimal efficacy. These complex relationships have allowed us to be able to detect hysteresis loops and to begin to understand the various mechanisms of action, metabolic and rate limiting steps that cause them. It can be observed that there are various modeling alternatives to collapsing hysteresis loops when determining PK and PD estimates. Special attention needs to be placed on the study design with the various caveats that could arise from the selection of PD estimates as well as the selection of formulation and route of administration. Interdisciplinary approaches are warranted to aid in the further understanding of hysteresis loops to help us develop drugs with a clearer understanding of their complicated pharmacokinetic-pharmacodynamic interactions and behaviours.

\section{ACKNOWLEDGMENTS}

The authors would like to acknowledge the assistance of Nicole R. Messinbird BSc(Pharm) for initial collation of some references utilized for this paper and Dr. Matthew R. Wright for his seminal discussions and insights on this topic in the early 1990's.

\section{REFERENCES}

1. P.L. Bonate, D.R. Howard, Chapter 6: Role of preclinical pharmacokinetics in drug development, in: P.L. Bonate, D.R. Howard (Eds.) Pharmacokinetics in drug development, AAPS Press, Arlington, VA, 2004, pp. 146.
2. P. Girard, J.P. Boissel, Clockwise hysteresis or proteresis, Journal of pharmacokinetics and biopharmaceutics, 17 (1989) 401-402.

3. L.B. Sheiner, D.R. Stanski, S. Vozeh, R.D. Miller, J. Ham, Simultaneous modeling of pharmacokinetics and pharmacodynamics: application to dtubocurarine, Clinical pharmacology and therapeutics, 25 (1979) 358-371.

4. J.P. Remington, A.R. Gennaro, Remington: The science and practice of pharmacy, 21 ed., Mack Publishing, Easton, PA, 2006.

5. D.B. Campbell, The use of kinetic-dynamic interactions in the evaluation of drugs, Psychopharmacology (Berl), 100 (1990) 433-450.

6. Y. Kwon, Handbook of essential pharmacokinetics, pharmacodynamis, and drug metabolism for industrial scientists, Kluwer Academic/Plenum Publishers, New York, 2001.

7. L.A. Bauer, Chapter 8: Clinical pharmacokinetics and pharmacodynamics, in: R.L. Talbert, J.T. DiPiro, G.R. Matzke, L.M. Posey, B.G. Wells, G.C. Yee (Eds.) Pharmacotherapy: A Pathophysiologic Approach, McGraw-Hill, New York, 2011.

8. S.K. Gupta, S.S. Hwang, L.Z. Benet, M. Gumbleton, Interpretation and utilization of effect and concentration data collected in an in vivo pharmacokinetic and in vitro pharmacodynamic study, Pharmaceutical research, 10 (1993) 889-894.

9. J.L. Pedraz, B. Calvo, J.A. Smithers, G.A. Thompson, Pharmacokinetic-pharmacodynamic modeling: time-dependent protein binding--an alternative interpretation of clockwise and counterclockwise hysteresis, Journal of pharmaceutical sciences, 81 (1992) 232-236.

10. R. Mehvar, Stereochemical considerations in pharmacodynamic modeling of chiral drugs, Journal of pharmaceutical sciences, 81 (1992) 199-200.

11. M. Miyamoto, T. Tsukune, S. Hori, T. Hayashi, H. Natsume, K. Sugibayashi, Y. Morimoto, Estimation of absorption rate of alpha-human atrial natriuretic peptide from the plasma profile and diuretic effect after intranasal administration to rats, Biopharmaceutics \& drug disposition, 22 (2001) 137-146.

12. E. Kim, O.D. Howes, B.H. Kim, J.M. Jeong, J.S. Lee, I.J. Jang, S.G. Shin, F.E. Turkheimer, S. Kapur, J.S. Kwon, Predicting brain occupancy from plasma levels using PET: superiority of combining pharmacokinetics with pharmacodynamics while modeling the relationship, Journal of cerebral blood flow and metabolism : official journal of the International Society of Cerebral Blood Flow and Metabolism, 32 (2012) 759-768.

13. J. Song, J. Li, Y. Jin, H. Wang, S. Zheng, J. Gao, Pharmacokinetic-pharmacodynamic evaluation of the major component astragaloside IV on the immunomodulatory effects of Yu-ping-feng 
prescription, Eur J European Journal of Drug Metabolism and Pharmacokinetics, (2013).

14. J. Jia, C. Dong, W. Zhang, Y. Cui, J. Liu, Evaluation of pharmacokinetic and pharmacodynamic relationship for oral sustained-release atenolol pellets in rats, J Pharm Biomed Anal, 55 (2011) 342348.

15. C. Farenc, J.Y. Lefrant, M. Audran, F. Bressolle, Pharmacokinetic-pharmacodynamic modeling of atracurium in intensive care patients, Journal of clinical pharmacology, 41 (2001) 44-50.

16. H. Ohtani, C. Taninaka, E. Hanada, H. Kotaki, H. Sato, Y. Sawada, T. Iga, Comparative pharmacodynamic analysis of Q-T interval prolongation induced by the macrolides clarithromycin, roxithromycin, and azithromycin in rats, Antimicrobial agents and chemotherapy, 44 (2000) 2630-2637.

17. G.N. Balerio, M.C. Rubio, Pharmacokineticpharmacodynamic modeling of the antinociceptive effect of baclofen in mice, European journal of drug metabolism and pharmacokinetics, 27 (2002) 163169.

18. H. Kobayashi, S. Kobayashi, Relationship between plasma concentration and antihypertensive effect of the dihydropyridine calcium antagonist, benidipine, in rats, The Journal of pharmacy and pharmacology, 49 (1997) 1200-1204.

19. M. Atsumi, J. Kawakami, E. Sugiyama, H. Kotaki, Y. Sawada, H. Sato, Y. Yamada, T. Iga, Pharmacokinetic and pharmacodynamic analyses, based on dopamine D2-receptor occupancy of bromocriptine, of bromocriptine-induced contralateral rotations in unilaterally 6-OHDAlesioned rats, Synapse (New York, N.Y.), 50 (2003) 110-116.

20. N. Yagi, T. Kiuchi, H. Satoh, Y. Ishikawa, M. Takada, H. Sekikawa, Bioavailability and diuretic effect after administration of retarded capsules of bumetanide in human subjects, Biol Pharm Bull, 22 (1999) 275-280.

21. Y. Koike, S. Mineshita, H. Mizoguchi, Y. Nomura, Pharmacokinetics and pharmacodynamics of bunazosin in patients with renal insufficiency, American Journal of Therapeutics, 6 (1999) 83-89.

22. B. Fuchs, K. Breithaupt-Grogler, G.G. Belz, S. Roll, C. Malerczyk, V. Herrmann, H. Spahn-Langguth, E. Mutschler, Comparative pharmacodynamics and pharmacokinetics of candesartan and losartan in man, The Journal of pharmacy and pharmacology, 52 (2000) 1075-1083.

23. C. Malerczyk, B. Fuchs, G.G. Belz, S. Roll, R. Butzer, K. Breithaupt-Grogler, V. Herrmann, S.G. Magin, A. Hogemann, B. Voith, E. Mutschler, Angiotensin II antagonism and plasma radioreceptor-kinetics of candesartan in man, British journal of clinical pharmacology, 45 (1998) 567573.

24. R.K. Brazzell, K.C. Khoo, A.J. Szuna, D. Sandor, K. Aogaichi, R.J. Wills, Pharmacokinetics and pharmacodynamics of intravenous cibenzoline in normal volunteers, Journal of clinical pharmacology, 25 (1985) 418-423.

25. H.C. Porchet, P. Piletta, P. Dayer, Pharmacokineticpharmacodynamic modeling of the effects of clonidine on pain threshold, blood pressure, and salivary flow, European journal of clinical pharmacology, 42 (1992) 655-661.

26. M. Fukudo, I. Yano, S. Masuda, M. Okuda, K. Inui, Distinct inhibitory effects of tacrolimus and cyclosporin a on calcineurin phosphatase activity, The Journal of pharmacology and experimental therapeutics, 312 (2005) 816-825.

27. E.B. Belldina, M.Y. Huang, J.A. Schneider, R.C. Brundage, T.S. Tracy, Steady-state pharmacokinetics and pharmacodynamics of cysteamine bitartrate in paediatric nephropathic cystinosis patients, British journal of clinical pharmacology, 56 (2003) 520-525.

28. H.L. Rowley, R. Kulkarni, J. Gosden, R. Brammer, D. Hackett, D.J. Heal, Lisdexamfetamine and immediate release d-amfetamine - differences in pharmacokinetic/pharmacodynamic relationships revealed by striatal microdialysis in freely-moving rats with simultaneous determination of plasma drug concentrations and locomotor activity, Neuropharmacology, 63 (2012) 1064-1074.

29. J.E. Torres-Lopez, F.J. Lopez-Munoz, G. CastanedaHernandez, F.J. Flores-Murrieta, V. Granados-Soto, Pharmacokinetic-pharmacodynamic modeling of the antinociceptive effect of diclofenac in the rat, The Journal of pharmacology and experimental therapeutics, 282 (1997) 685-690.

30. J. Lötsch, B Kettenmann, B Renner, D Drover, K Brune, G Geisslinger, G Kobal , Population pharmacokinetics of fast release oral diclofenac in healthy volunteers: relation to pharmacodynamics in an experimental pain model, Pharmaceutical Research, 17 (2000) 77-84.

31. F. Le Coz, C. Funck-Brentano, T. Morell, M.M. Ghadanfar, P. Jaillon, Pharmacokinetic and pharmacodynamic modeling of the effects of oral and intravenous administrations of dofetilide on ventricular repolarization, Clinical pharmacology and therapeutics, 57 (1995) 533-542.

32. B.P. Imbimbo, M. Licini, M. Schettino, A. Mosca, E. Onelli, L. Zecca, A. Giustina, Relationship between pharmacokinetics and pharmacodynamics of eptastigmine in young healthy volunteers, Journal of clinical pharmacology, 35 (1995) 285-290.

33. M. Kreilgaard, D.G. Smith, L.T. Brennum, C. Sanchez, Prediction of clinical response based on pharmacokinetic/pharmacodynamic models of 5- 
hydroxytryptamine reuptake inhibitors in mice, British journal of pharmacology, 155 (2008) 276284.

34. R. Larsson, B.E. Karlberg, A. Gelin, J. Aberg, C.G. Regardh, Acute and steady-state pharmacokinetics and antihypertensive effects of felodipine in patients with normal and impaired renal function, Journal of clinical pharmacology, 30 (1990) 1020-1030.

35. F. Formelli, E. Cavadini, R. Luksch, A. Garaventa, V. Appierto, S. Persiani, Relationship among pharmacokinetics and pharmacodynamics of fenretinide and plasma retinol reduction in neuroblastoma patients, Cancer chemotherapy and pharmacology, 66 (2010) 993-998.

36. F.I. Vyas, S. Prakash, A.J. Singh, QTc interval prolongation by fexofenadine in healthy human volunteers and its correlation with plasma levels of fexofenadine: A demonstration of anticlockwise hysteresis, Indian journal of pharmacology, 42 (2010) 366-369.

37. N.M. Davies, F. Jamali, Influence of dosage form on the gastroenteropathy of flurbiprofen in the rat: evidence of shift in the toxicity site, Pharmaceutical research, 14 (1997) 1597-1600.

38. G. Alvan, G. Paintaud, S.A. Eckernas, A. Grahnen, Discrepancy between bioavailability as estimated from urinary recovery of frusemide and total diuretic effect, British journal of clinical pharmacology, 34 (1992) 47-52.

39. N. Yagi, T. Kiuchi, H. Satoh, Y. Terashima, H. Kenmotsu, H. Sekikawa, M. Takada, Bioavailability and diuretic effect of furosemide following administration of tablets and retarded capsules to human subjects, Biol Pharm Bull, 19 (1996) 616622.

40. H.S. Abou-Auda, Comparative pharmacokinetics and pharmacodynamics of furosemide in Middle Eastern and in Asian subjects, Int J Clin Pharmacol Ther, 36 (1998) 275-281.

41. M. Wakelkamp, G. Alvan, H. Scheinin, J. Gabrielsson, The influence of drug input rate on the development of tolerance to frusemide, British journal of clinical pharmacology, 46 (1998) 479487.

42. M.R. Wright, N.M. Davies, F. Jamali, Toxicokinetics of indomethacin-induced intestinal permeability in the rat, Pharmacol Res, 35 (1997) 499-504.

43. X.H. Huang, J. Li, F.R. Qiu, H.T. Xie, J.H. Huang, J.C. Li, Q.S. Zheng, PK-PD modeling of irbesartan in healthy Chinese adult volunteers under nonsteady-state conditions, European journal of drug metabolism and pharmacokinetics, 31 (2006) 259264.

44. R.A. Morrison, U.W. Wiegand, E. Jahnchen, D. Hohmann, H. Bechtold, T. Meinertz, H.L. Fung, Isosorbide dinitrate kinetics and dynamics after intravenous, sublingual, and percutaneous dosing in angina, Clinical pharmacology and therapeutics, 33 (1983) 747-756.

45. V. Carrara, H. Porchet, P. Dayer, Influence of input rates on (+/-)-isradipine haemodynamics and concentration-effect relationship in healthy volunteers, European journal of clinical pharmacology, 46 (1994) 29-33.

46. S.K. Quinney, R.E. Galinsky, V.A. Jiyamapa-Serna, Y. Chen, M.A. Hamman, S.D. Hall, R.E. Kimura, Hydroxyitraconazole, formed during intestinal firstpass metabolism of itraconazole, controls the time course of hepatic CYP3A inhibition and the bioavailability of itraconazole in rats, Drug metabolism and disposition: the biological fate of chemicals, 36 (2008) 1097-1101.

47. K. Ikawa, T. Shimatani, S. Hayato, N. Morikawa, S. Tazuma, Pharmacokinetic and pharmacodynamic properties of lafutidine after postprandial oral administration in healthy subjects: comparison with famotidine, Biological \& pharmaceutical bulletin, 30 (2007) 1003-1006.

48. P. Poder, J. Eha, S. Sundberg, S. Antila, M. Heinpalu, I. Loogna, U. Planken, S. Rantanen, L. Lehtonen, Pharmacokinetic-pharmacodynamic interrelationships of intravenous and oral levosimendan in patients with severe congestive heart failure, International journal of clinical pharmacology and therapeutics, 41 (2003) 365-373.

49. S. Sundberg, S. Antila, H. Scheinin, M. Hayha, M. Virtanen, L. Lehtonen, Integrated pharmacokinetics and pharmacodynamics of the novel calcium sensitizer levosimendan as assessed by systolic time intervals, International journal of clinical pharmacology and therapeutics, 36 (1998) 629-635.

50. M.L. Huang, A. Van Peer, R. Woestenborghs, R. De Coster, J. Heykants, A.A. Jansen, Z. Zylicz, H.W. Visscher, J.H. Jonkman, Pharmacokinetics of the novel antipsychotic agent risperidone and the prolactin response in healthy subjects, Clinical pharmacology and therapeutics, 54 (1993) 257-268.

51. S.K. Gupta, E.H. Ellinwood, A.M. Nikaido, D.G. Heatherly, Simultaneous modeling of the pharmacokinetic and pharmacodynamic properties of benzodiazepines. I: Lorazepam, Journal of pharmacokinetics and biopharmaceutics, 18 (1990) 89-102.

52. D.J. Greenblatt, L.L. von Moltke, B.L. Ehrenberg, J.S. Harmatz, K.E. Corbett, D.W. Wallace, R.I. Shader, Kinetics and dynamics of lorazepam during and after continuous intravenous infusion, Critical care medicine, 28 (2000) 2750-2757.

53. R.N. Upton, Y.F. Huang, L.E. Mather, D.J. Doolette, The relationship between the myocardial kinetics of meperidine and its effect on myocardial contractility: model-independent analysis and optimal regional 
model, The Journal of pharmacology and experimental therapeutics, 290 (1999) 694-701.

54. S.H. Lee, K.I. Kwon, Pharmacokineticpharmacodynamic modeling for the relationship between glucose-lowering effect and plasma concentration of metformin in volunteers, Archives of pharmacal research, 27 (2004) 806-810.

55. S.L. Shafer, J.R. Varvel, G.A. Gronert, A comparison of parametric with semiparametric analysis of the concentration versus effect relationship of metocurine in dogs and pigs, Journal of pharmacokinetics and biopharmaceutics, 17 (1989) 291-304.

56. B. Rosenkranz, B.R. Winkelmann, M.J. Parnham, Clinical pharmacokinetics of molsidomine, Clinical pharmacokinetics, 30 (1996) 372-384.

57. J.D. Hoekman, R.J. Ho, Enhanced analgesic responses after preferential delivery of morphine and fentanyl to the olfactory epithelium in rats, Anesthesia and analgesia, 113 (2011) 641-651.

58. J.T. Van Crugten, A.A. Somogyi, R.L. Nation, Effect of uranyl nitrate-induced renal failure on morphine disposition and antinociceptive response in rats, Clinical and experimental pharmacology \& physiology, 27 (2000) 74-79.

59. G.W. Shang, D.N. Liu, L.H. Yan, X.Y. Cui, K.P. Zhang, C. Qi, J. Chen, Nociceptive stimulus modality-related difference in pharmacokineticpharmacodynamic modeling of morphine in the rat, Pharmacol Biochem Behav, 85 (2006) 464-473.

60. G. Castaneda-Hernandez, L. Favari, C. HoyoVadillo, Relationship between naproxen plasma concentration and its anti-inflammatory effect in experimental hepatitis, Arzneimittel-Forschung, 45 (1995) 585-589.

61. P.K. Noonan, R.L. Williams, L.Z. Benet, Dose dependent pharmacokinetics of nitroglycerin after multiple intravenous infusions in healthy volunteers, Journal of pharmacokinetics and biopharmaceutics, 13 (1985) 143-157.

62. F.W. Lee, T. Salmonson, L.Z. Benet, Pharmacokinetics and pharmacodynamics of nitroglycerin and its dinitrate metabolites in conscious dogs: intravenous infusion studies, Journal of pharmacokinetics and biopharmaceutics, 21 (1993) 533-550.

63. J.R. Woodworth, D.C. Howey, R.R. Bowsher, Establishment of time-action profiles for regular and NPH insulin using pharmacodynamic modeling, Diabetes Care, 17 (1994) 64-69.

64. D. Brockmeier, P. Hajdu, W. Henke, E. Mutschler, D. Palm, W. Rupp, H. Spahn, M.T. Verho, A. Wellstein, Penbutolol: pharmacokinetics, effect on exercise tachycardia, and in vitro inhibition of radioligand binding, European journal of clinical pharmacology, 35 (1988) 613-623.
65. K.M. Chu, O.Y. Hu, S.M. Shieh, Cardiovascular effect and simultaneous pharmacokinetic and pharmacodynamic modeling of pimobendan in healthy normal subjects, Drug metabolism and disposition: the biological fate of chemicals, 27 (1999) 701-709.

66. P. Girard, J.L. Saumet, F. Dubois, J.P. Boissel, Pharmacodynamic model of the haemodynamic effects of pinacidil in normotensive volunteers, European journal of clinical pharmacology, 44 (1993) 177-182.

67. M.R. Feng, D. Turluck, J. Burleigh, R. Lister, C. Fan, A. Middlebrook, C. Taylor, T. Su, Brain microdialysis and $\mathrm{PK} / \mathrm{PD}$ correlation of pregabalin in rats, European journal of drug metabolism and pharmacokinetics, 26 (2001) 123-128.

68. G.L. Ludbrook, R.N. Upton, C. Grant, E.C. Gray, Brain and blood concentrations of propofol after rapid intravenous injection in sheep, and their relationships to cerebral effects, Anaesthesia and Intensive Care, 24 (1996) 445-452.

69. D.J. Hermann, T.D. Egan, K.T. Muir, Influence of arteriovenous sampling on remifentanil pharmacokinetics and pharmacodynamics, Clinical pharmacology and therapeutics, 65 (1999) 511-518.

70. D.Y. Lee, K.U. Lee, J.S. Kwon, I.J. Jang, M.J. Cho, S.G. Shin, J.I. Woo, Pharmacokineticpharmacodynamic modeling of risperidone effects on electroencephalography in healthy volunteers, Psychopharmacology, 144 (1999) 272-278.

71. D.W. Han, K. Park, S.B. Jang, S.E. Kern, Modeling the effect of sevoflurane on corrected QT prolongation: a pharmacodynamic analysis, Anesthesiology, 113 (2010) 806-811.

72. M.V. Nelson, R.C. Berchou, P.A. Lewitt, D. Kareti, N. Kesaree, P. Schlick, M.P. Galloway, Pharmacokinetic and pharmacodynamic modeling of L-dopa plasma concentrations and clinical effects in Parkinson's disease after Sinemet, Clinical neuropharmacology, 12 (1989) 91-97.

73. T. Minematsu, H. Ohtani, Y. Yamada, Y. Sawada, H. Sato, T. Iga, Quantitative relationship between myocardial concentration of tacrolimus and QT prolongation in guinea pigs: pharmacokinetic/pharmacodynamic model incorporating a site of adverse effect, Journal of pharmacokinetics and pharmacodynamics, 28 (2001) 533-554.

74. J. Stangier, C.A. Su, P.N. van Heiningen, T. Meinicke, J.J. van Lier, H. de Bruin, W.J. Tamminga, J.H. Jonkman, Inhibitory effect of telmisartan on the blood pressure response to angiotensin II challenge, Journal of cardiovascular pharmacology, 38 (2001) 672-685.

75. T. Lehr, A. Staab, C. Tillmann, E.O. Nielsen, D. Trommeshauser, H.G. Schaefer, C. Kloft, Contribution of the active metabolite M1 to the 
pharmacological activity of tesofensine in vivo: a pharmacokinetic-pharmacodynamic modelling approach, British journal of pharmacology, 153 (2008) 164-174.

76. R.N. Upton, Y.F. Huang, C. Grant, E.C. Gray, G.L. Ludbrook, Myocardial pharmacokinetics of thiopental in sheep after short-term administration: relationship to thiopental-induced reductions in myocardial contractility, Journal of pharmaceutical sciences, 85 (1996) 863-867.

77. C.J. Brindley, T. Taylor, V. Diness, P.B. Oestergaard, L.F. Chasseaud, Relationship between pharmacokinetics and pharmacodynamics of tinzaparin (logiparin), a low molecular weight heparin, in dogs, Xenobiotica; the fate of foreign compounds in biological systems, 23 (1993) 575588.

78. S.K. Gupta, E.H. Ellinwood, A.M. Nikaido, D.G. Heatherly, Simultaneous modeling of the pharmacokinetic and pharmacodynamic properties of benzodiazepines. II. Triazolam, Pharmaceutical research, 7 (1990) 570-576.

79. R.J. Wills, H.E. Gallo-Torres, R. Bertko, B.H. Min, Pharmacokinetics and antisecretory activity of trimoprostil in Heidenhain-pouch dogs, The Journal of pharmacology and experimental therapeutics, 241 (1987) 433-437.

80. C.E. Wright, T.L. Sisson, J.C. Fleishaker, E.J. Antal, Pharmacokinetics and psychomotor performance of alprazolam: concentration-effect relationship, Journal of clinical pharmacology, 37 (1997) 321329.

81. M.J. Barbanoj, G. Urbano, R. Antonijoan, M.R. Ballester, M. Valle, Different acute tolerance development to EEG, psychomotor performance and subjective assessment effects after two intermittent oral doses of alprazolam in healthy volunteers, Neuropsychobiology, 55 (2007) 203-212.

82. S.K. Gupta, J. Shah, D. Guinta, S. Hwang, Multipledose pharmacokinetics and pharmacodynamics of OROS and immediate-release amitriptyline hydrochloride formulations, Journal of clinical pharmacology, 38 (1998) 60-67.

83. S. Harder, H. Baas, L. Demisch, E. Simon, Dose response and concentration response relationship of apomorphine in patients with Parkinson's disease and end-of-dose akinesia, Int J Clin Pharmacol Ther, 36 (1998) 355-362.

84. A. Patat, F. le Coz, C. Dubruc, J.M. Gandon, G. Durrieu, I. Cimarosti, S. Jezequel, O. Curet, I. Zieleniuk, H. Allain, P. Rosenzweig, Pharmacodynamics and pharmacokinetics of two dose regimens of befloxatone, a new reversible and selective monoamine oxidase inhibitor, at steady state in healthy volunteers, Journal of clinical pharmacology, 36 (1996) 216-229.
85. E.H. Ellinwood, A. Nikaido, D. Heatherly, Diazepam: prediction of pharmacodynamics from pharmacokinetics, Psychopharmacology (Berl), 83 (1984) 297-298.

86. R.A. Boyd, S.K. Chin, O. Don-Pedro, D. Verotta, L.B. Sheiner, R.L. Williams, K.M. Giacomini, The pharmacokinetics and pharmacodynamics of diltiazem and its metabolites in healthy adults after a single oral dose, Clinical pharmacology and therapeutics, 46 (1989) 408-419.

87. V. Luckow, O. Della Paschoa, PK/PD modelling of high-dose diltiazem--absorption-rate dependency of the hysteresis loop, Int $\mathbf{J}$ Clin Pharmacol Ther, 35 (1997) 418-425.

88. Y. Ito, T. Harada, K. Fushimi, Y. Kagawa, H. Oka, H. Nakazawa, R. Homma, Y. Kato, S. Yamada, Pharmacokinetic and pharmacodynamic analysis of acetylcholinesterase inhibition by distigmine bromide in rats, Drug Metab Pharmacokinet, 25 (2010) 254-261.

89. M.M. Hammarlund, B. Odlind, L.K. Paalzow, Acute tolerance to furosemide diuresis in humans. Pharmacokinetic-pharmacodynamic modeling, The Journal of pharmacology and experimental therapeutics, 233 (1985) 447-453.

90. M. Boyko, D. Stepensky, B.F. Gruenbaum, S.E. Gruenbaum, I. Melamed, S. Ohayon, M. Glazer, Y. Shapira, A. Zlotnik, Pharmacokinetics of glutamateoxaloacetate transaminase and glutamate-pyruvate transaminase and their blood glutamate-lowering activity in naive rats, Neurochem Res, 37 (2012) 2198-2205.

91. M.J. Kemme, J. Burggraaf, R.C. Schoemaker, C. Kluft, A.F. Cohen, Quantification of heparininduced TFPI release: a maximum release at low heparin dose, British journal of clinical pharmacology, 54 (2002) 627-634.

92. M.R. Marino, K.M. Langenbacher, N.F. Ford, R.H. Raymond, J. Manning, O. Vesterqvist, E.C. Shamblen, K.C. Lasseter, Pharmacodynamics and Pharmacokinetics of Irbesartan in Patients With Mild to Moderate Hypertension, J Cardiovasc Pharmacol Ther, 4 (1999) 67-75.

93. T. Aoyama, K. Yamamoto, H. Kotaki, Y. Sawada, T. Iga, Pharmacodynamic modeling for change of locomotor activity by methylphenidate in rats, Pharmaceutical research, 14 (1997) 1601-1606.

94. T.W. Gehr, D.A. Sica, D.C. Brater, H.J. Wallace, J. Davis, I. Fakhry, Metolazone pharmacokinetics and pharmacodynamics in renal transplantation, International journal of clinical pharmacology, therapy, and toxicology, 29 (1991) 116-123.

95. G. Aymard, D. Warot, P. Demolis, J.F. Giudicelli, P. Lechat, M.E. Le Guern, C. Alquier, B. Diquet, Comparative pharmacokinetics and pharmacodynamics of intravenous and oral nefopam 
in healthy volunteers, Pharmacol Toxicol, 92 (2003) 279-286.

96. D. Kietzmann, T. Bouillon, C. Hamm, K. Schwabe, H. Schenk, U. Gundert-Remy, D. Kettler, Pharmacodynamic modelling of the analgesic effects of piritramide in postoperative patients, Acta anaesthesiologica Scandinavica, 41 (1997) 888-894.

97. P. De Paepe, F.M. Belpaire, M.T. Rosseel, G. Van Hoey, P.A. Boon, W.A. Buylaert, Influence of hypovolemia on the pharmacokinetics and the electroencephalographic effect of propofol in the rat, Anesthesiology, 93 (2000) 1482-1490.

98. E.H. Cox, C.A. Knibbe, V.S. Koster, M.W. Langemeijer, E.E. Tukker, R. Lange, P.F. Kuks, H.J. Langemeijer, A.H.L. Lie, M. Danhof, Influence of different fat emulsion-based intravenous formulations on the pharmacokinetics and pharmacodynamics of propofol, Pharmaceutical research, 15 (1998) 442-448.

99. M. Liem-Moolenaar, P. de Boer, M. Timmers, R.C. Schoemaker, J.G. van Hasselt, S. Schmidt, J.M. van Gerven, Pharmacokinetic-pharmacodynamic relationships of central nervous system effects of scopolamine in healthy subjects, British journal of clinical pharmacology, 71 (2011) 886-898.

100.A.W. Fox, B.W. Sullivan, J.D. Buffini, M.L. Neichin, R. Nicora, F.K. Hoehler, R. O'Rourke, R.R. Stoltz, Reduction of serum lactate by sodium dichloroacetate, and human pharmacokineticpharmacodynamic relationships, The Journal of pharmacology and experimental therapeutics, 279 (1996) 686-693.

101.P.D. Kroboth, R.B. Smith, R. Rault, M.R. Silver, M.I. Sorkin, J.B. Puschett, R.P. Juhl, Effects of endstage renal disease and aluminum hydroxide on temazepam kinetics, Clinical pharmacology and therapeutics, 37 (1985) 453-459.

102.H. Luurila, K.T. Olkkola, Pharmacokineticpharmacodynamic modelling of zopiclone effects on human central nervous system, Pharmacol Toxicol, 78 (1996) 348-353.

103.D. Verotta, S.L. Beal, L.B. Sheiner, Semiparametric approach to pharmacokinetic-pharmacodynamic data, Am J Physiol, 256 (1989) R1005-1010.

104.W.L. Chiou, The phenomenon and rationale of marked dependence of drug concentration on blood sampling site. Implications in pharmacokinetics, pharmacodynamics, toxicology and therapeutics (Part I), Clinical pharmacokinetics, 17 (1989) 175199.

105.W.L. Chiou, The phenomenon and rationale of marked dependence of drug concentration on blood sampling site. Implications in pharmacokinetics, pharmacodynamics, toxicology and therapeutics (Part II), Clinical pharmacokinetics, 17 (1989) 275290.
106.J.R. Jacobs, P.A. Nath, Compartment model to describe peripheral arterial-venous drug concentration gradients with drug elimination from the venous sampling compartment, Journal of pharmaceutical sciences, 84 (1995) 370-375.

107.C.W. Chiang, G. Barnett, Marijuana effect and delta-9-tetrahydrocannabinol plasma level, Clinical pharmacology and therapeutics, 36 (1984) 234-238.

108.U. Thadani, H.L. Fung, A.C. Darke, J.O. Parker, Oral isosorbide dinitrate in the treatment of angina pectoris. Dose-response relationship and duration of action during acute therapy, Circulation, 62 (1980) 491-502.

109.M.G. Bogaert, M.T. Rosseel, Vascular effects of the dinitrate and moninitrate esters of isosorbide, isomannide and isoidide, Naunyn Schmiedebergs Arch Pharmacol, 275 (1972) 339-342.

110.R.L. Wendt, Systemic and coronary vascular effects of the 2- and the 5-mononitrate esters of isosorbide, The Journal of pharmacology and experimental therapeutics, 180 (1972) 732-742.

111.B.J. Pleuvry, Hysteresis in drug response, Anaesthesia \& Intensive Care Medicine, 9 (2008) 372-373.

112.S. Kapur, P. Seeman, Antipsychotic agents differ in how fast they come off the dopamine D2 receptors. Implications for atypical antipsychotic action, $\mathrm{J}$ Psychiatry Neurosci, 25 (2000) 161-166.

113.W. Wienen, M. Entzeroth, J.C.A. van Meel, J. Stangier, U. Busch, T. Ebner, J. Schmid, H. Lehmann, K. Matzek, J. Kempthorne-Rawson, V. Gladigau, N.H. Hauel, A Review on Telmisartan: A Novel, Long-Acting Angiotensin II-Receptor Antagonist, Cardiovascular Drug Reviews, 18 (2000) 127-154.

114.W. Wienen, N. Hauel, J.C. Van Meel, B. Narr, U. Ries, M. Entzeroth, Pharmacological characterization of the novel nonpeptide angiotensin II receptor antagonist, BIBR 277, British journal of pharmacology, 110 (1993) 245-252.

115.Y. Inoue, N. Nakamura, T. Inagami, A review of mutagenesis studies of angiotensin II type 1 receptor, the three-dimensional receptor model in search of the agonist and antagonist binding site and the hypothesis of a receptor activation mechanism, $\mathrm{J}$ Hypertens, 15 (1997) 703-714.

116.H.T. Schambye, S.A. Hjorth, D.J. Bergsma, G. Sathe, T.W. Schwartz, Differentiation between binding sites for angiotensin II and nonpeptide antagonists on the angiotensin II type 1 receptors, Proc Natl Acad Sci U S A, 91 (1994) 7046-7050.

117.H.R. Brunner, J. Nussberger, B. Waeber, Angiotensin II blockade compared with other pharmacological methods of inhibiting the reninangiotensin system, J Hypertens Suppl, 11 (1993) S53-58. 
118.E. Delacretaz, J. Nussberger, J. Biollaz, B. Waeber, H.R. Brunner, Characterization of the angiotensin II receptor antagonist TCV-116 in healthy volunteers, Hypertension, 25 (1995) 14-21.

119.M. Ojima, Y. Inada, Y. Shibouta, T. Wada, T. Sanada, K. Kubo, K. Nishikawa, Candesartan (CV11974) dissociates slowly from the angiotensin AT1 receptor, European journal of pharmacology, 319 (1997) 137-146.

120.G.G. Belz, R. Butzer, C. Mang, S. Kober, E. Mutschler, Greater extent and duration of the inhibitory effect of irbesartan on angiotensin II challenge in man compared to losartan and valsartan, European journal of clinical pharmacology, 54 (1998) A8.

121.J. Ostrowski, P. Schweizer, R. Erbel, Correlation of pharmacokinetic data to clinical effect of molsidomine, in: Proceedings of the First European Congress on Biopharmacology and Pharmacokinetics, Clermont-Ferrand, France, 1981, pp. 418-424.

122.T. Meinertz, A. Brandstatter, D. Trenk, E. Jahnchen, J. Ostrowski, W. Gartner, Relationship between pharmacokinetics and pharmacodynamics of molsidomine and its metabolites in humans, American heart journal, 109 (1985) 644-648.

123.C. Crevoisier, W.H. Ziegler, M. Eckert, P. Heizmann, Relationship between plasma concentration and effect of midazolam after oral and intravenous administration, British journal of clinical pharmacology, 16 Suppl 1 (1983) 51S-61S.

124.T.C. Hardin, J.R. Graybill, R. Fetchick, R. Woestenborghs, M.G. Rinaldi, J.G. Kuhn, Pharmacokinetics of itraconazole following oral administration to normal volunteers, Antimicrobial agents and chemotherapy, 32 (1988) 1310-1313.

125.J. Heykants, A. Van Peer, V. Van de Velde, P. Van Rooy, W. Meuldermans, K. Lavrijsen, R. Woestenborghs, J. Van Cutsem, G. Cauwenbergh, The clinical pharmacokinetics of itraconazole: an overview, Mycoses, 32 Suppl 1 (1989) 67-87.

126.J.H. Shin, K.Y. Choi, Y.C. Kim, M.G. Lee, Dosedependent pharmacokinetics of itraconazole after intravenous or oral administration to rats: intestinal first-pass effect, Antimicrobial agents and chemotherapy, 48 (2004) 1756-1762.

127.S.D. Yoo, E. Kang, H. Jun, B.S. Shin, K.C. Lee, K.H. Lee, Absorption, first-pass metabolism, and disposition of itraconazole in rats, Chemical \& pharmaceutical bulletin, 48 (2000) 798-801.

128.J.M. Poirier, G. Cheymol, Optimisation of itraconazole therapy using target drug concentrations, Clinical pharmacokinetics, 35 (1998) 461-473.

129.S. Knapp, M.L. Wardlow, K. Albert, D. Waters, L.J. Thal, Correlation between plasma physostigmine concentrations and percentage of acetylcholinesterase inhibition over time after controlled release of physostigmine in volunteer subjects, Drug metabolism and disposition: the biological fate of chemicals, 19 (1991) 400-404.

130.P.L. Moriearty, R.E. Becker, Inhibition of human brain and RBC acetylcholinesterase (AChE) by heptylphysostigmine (HPTL), Methods and findings in experimental and clinical pharmacology, 14 (1992) 615-621.

131.L.K. Unni, V. Hutt, B.P. Imbimbo, R.E. Becker, Kinetics of cholinesterase inhibition by eptastigmine in man, European journal of clinical pharmacology, 41 (1991) 83-84.

132.M. Brufani, M. Marta, M. Pomponi, Anticholinesterase activity of a new carbamate, heptylphysostigmine, in view of its use in patients with Alzheimer-type dementia, Eur J Biochem, 157 (1986) 115-120.

133.A. Auteri, A. Mosca, N. Lattuada, M. Luzzana, L. Zecca, D. Radice, B.P. Imbimbo, Pharmacodynamics and pharmacokinetics of eptastigmine in elderly subjects, European journal of clinical pharmacology, 45 (1993) 373-376.

134.R.H. Swift, T.G. Mant, A. Heald, D.G. Sciberras, B. Imbimbo, P.J. Morrison, M.R. Goldberg, A study to investigate the safety, tolerance, and pharmacodynamics of single rising doses of L693,487 (heptyl-physostigmine tartrate) in healthy elderly volunteers, in: British Pharmacological Society Joint Meeting with the Nordic Society, University of Southampton, UK, 1991.

135.S. Kaojarern, B. Day, D.C. Brater, The time course of delivery of furosemide into urine: an independent determinant of overall response, Kidney international, 22 (1982) 69-74.

136.M. Pennick, Absorption of lisdexamfetamine dimesylate and its enzymatic conversion to $\mathrm{d}$ amphetamine, Neuropsychiatr Dis Treat, 6 317-327.

137.J. Biederman, S.W. Boellner, A. Childress, F.A. Lopez, S. Krishnan, Y. Zhang, Lisdexamfetamine dimesylate and mixed amphetamine salts extendedrelease in children with ADHD: a double-blind, placebo-controlled, crossover analog classroom study, Biol Psychiatry, 62 (2007) 970-976.

138.S.B. Wigal, S.H. Kollins, A.C. Childress, L. Squires, A 13-hour laboratory school study of lisdexamfetamine dimesylate in school-aged children with attention-deficit/hyperactivity disorder, Child Adolesc Psychiatry Ment Health, 3 (2009) 17.

139.T. Wigal, M. Brams, M. Gasior, J. Gao, L. Squires, J. Giblin, Randomized, double-blind, placebocontrolled, crossover study of the efficacy and safety of lisdexamfetamine dimesylate in adults with attention-deficit/hyperactivity disorder: novel findings using a simulated adult workplace environment design, Behav Brain Funct, 634. 
140.H. Kalant, A.E. LeBlanc, R.J. Gibbins, Tolerance to, and dependence on, some non-opiate psychotropic drugs, Pharmacol Rev, 23 (1971) 135-191.

141.G.C. Rosenfeld, T.F. Burks, Single-dose tolerance to morphine hypothermia in the rat: differentiation of acute from long-term tolerance, The Journal of pharmacology and experimental therapeutics, 202 (1977) 654-659.

142.J. Schuttler, H. Schwilden, H. Stoeckel, Infusion strategies to investigate the pharmacokinetics and pharmacodynamics of hypnotic drugs: etomidate as an example, Eur J Anaesthesiol, 2 (1985) 133-142.

143.B.M. Jones, A. Vega, Cognitive performance measured on the ascending and descending limb of the blood alcohol curve, Psychopharmacologia, 23 (1972) 99-114.

144.C. Van Dyke, P. Jatlow, J. Ungerer, P.G. Barash, R. Byck, Oral cocaine: plasma concentrations and central effects, Science, 200 (1978) 211-213.

145.E.H. Ellinwood, Jr., D.G. Heatherly, A.M. Nikaido, T.D. Bjornsson, C. Kilts, Comparative pharmacokinetics and pharmacodynamics of lorazepam, alprazolam and diazepam, Psychopharmacology (Berl), 86 (1985) 392-399.

146.P.D. Kroboth, R.B. Smith, R.J. Erb, Tolerance to alprazolam after intravenous bolus and continuous infusion: psychomotor and EEG effects, Clinical pharmacology and therapeutics, 43 (1988) 270-277.

147.R.J. Bertz, P.D. Kroboth, F.J. Kroboth, I.J. Reynolds, F. Salek, C.E. Wright, R.B. Smith, Alprazolam in young and elderly men: sensitivity and tolerance to psychomotor, sedative and memory effects, The Journal of pharmacology and experimental therapeutics, 281 (1997) 1317-1329.

148.J.C. Fleishaker, J.H. Chambers, G.R. Peters, Evaluation of the development of acute tolerance to the psychomotor effects of midazolam following intravenous infusions in healthy volunteers, Human Psychopharmacology: Clinical and Experimental, 10 (1995) 97-104.

149.P.D. Kroboth, R.J. Bertz, R.B. Smith, Acute tolerance to triazolam during continuous and step infusions: estimation of the effect offset rate constant, The Journal of pharmacology and experimental therapeutics, 264 (1993) 1047-1055.

150.A.N. Bateson, Basic pharmacologic mechanisms involved in benzodiazepine tolerance and withdrawal, Current pharmaceutical design, 8 (2002) 5-21.

151.W. Sieghart, GABAA receptors: ligand-gated Clion channels modulated by multiple drug-binding sites, Trends Pharmacol Sci, 13 (1992) 446-450.

152.N. Holford, Holford NHG and Sheiner LB "Understanding the Dose-Effect RelationshipClinical Application of PharmacokineticPharmacodynamic Models", Clin Pharmacokin
6:429-453 (1981)-The Backstory, AAPS J, 13 (1981) 662-664.

153.M.L. Jack, W.A. Colburn, N.M. Spirt, G. Bautz, M. Zanko, W.D. Horst, R.A. O'Brien, A pharmacokinetic/pharmacodynamic/receptor binding model to predict the onset and duration of pharmacological activity of the benzodiazepines, Prog Neuropsychopharmacol Biol Psychiatry, 7 (1983) 629-635.

154.J.R. Wittenborn, Effects of benzodiazepines on psychomotor performance, British journal of clinical pharmacology, 7 Suppl 1 (1979) 61S-67S.

155.E.H. Ellinwood, Jr., M. Linnoila, M.E. Easler, D.W. Molter, Profile of acute tolerance to three sedative anxiolytics, Psychopharmacology (Berl), 79 (1983) 137-141.

156.M. Ekblom, M. Hammarlund-Udenaes, L. Paalzow, Modeling of tolerance development and rebound effect during different intravenous administrations of morphine to rats, The Journal of pharmacology and experimental therapeutics, 266 (1993) 244-252.

157.B. Oosterhuis, C.J. van Boxtel, Kinetics of drug effects in man, Therapeutic drug monitoring, 10 (1988) 121-132.

158.S.G. Carruthers, B. McCall, B.A. Cordell, R. Wu, Relationships between heart rate and PR interval during physiological and pharmacological interventions, British journal of clinical pharmacology, 23 (1987) 259-265.

159.M.S. Smith, C.P. Verghese, D.G. Shand, E.L. Pritchett, Pharmacokinetic and pharmacodynamic effects of diltiazem, Am J Cardiol, 51 (1983) 13691374.

160.K.A. Ellenbogen, S.F. Roark, M.S. Smith, E.A. McCarthy, T.D. Bjornsson, E.L. Pritchett, Effects of sustained intravenous diltiazem infusion in healthy persons, Am J Cardiol, 58 (1986) 1055-1060.

161.M. Joyal, J. Pieper, K. Cremer, R.L. Feldman, C.J. Pepine, Pharmacodynamic aspects of intravenous diltiazem administration, American heart journal, 111 (1986) 54-61.

162.S. Fukuhara, H. Echizen, M. Naito, S. Ishikawa, M. Toyama, H. Nagoshi, M. Honda, T. Ishizaki, An interindividual variability in the sensitivity of atrioventricular node to diltiazem in patients with paroxysmal supraventricular tachycardia, Journal of clinical pharmacology, 29 (1989) 102-106.

163.J.H. Zar, Biostatistical Analysis, 5th ed., Pearson, 2010.

164.N.H. Holford, L.B. Sheiner, Understanding the doseeffect relationship: clinical application of pharmacokinetic-pharmacodynamic models, Clinical pharmacokinetics, 6 (1981) 429-453.

165.D.R. Stanski, R.J. Hudson, T.D. Homer, L.J. Saidman, E. Meathe, Pharmacodynamic modeling of thiopental anesthesia, Journal of pharmacokinetics and biopharmaceutics, 12 (1984) 223-240. 
166.H.C. Porchet, N.L. Benowitz, L.B. Sheiner, J.R. Copeland, Apparent tolerance to the acute effect of nicotine results in part from distribution kinetics, $\mathrm{J}$ Clin Invest, 80 (1987) 1466-1471.

167.S.C. Montamat, D.R. Abernethy, Nmonodesmethyldiltiazem is the predominant metabolite of diltiazem in the plasma of young and elderly hypertensives, British journal of clinical pharmacology, 24 (1987) 185-189.

168.K.J. Goebel, E.U. Kolle, High-performance liquid chromatographic determination of diltiazem and four of its metabolites in plasma. Application to pharmacokinetics, J Chromatogr, 345 (1985) 355363.

169.J. Sugihara, Y. Sugawara, H. Ando, S. Harigaya, A. Etoh, K. Kohno, Studies on the metabolism of diltiazem in man, J Pharmacobiodyn, 7 (1984) 2432.

170.H. Yabana, T. Nagao, M. Sato, Cardiovascular effects of the metabolites of diltiazem in dogs, J Cardiovasc Pharmacol, 7 (1985) 152-157.

171.H. Narita, M. Otsuka, H. Yabana, T. Nagao, Hypotensive response of spontaneously hypertensive rats to centrally administered diltiazem and its metabolites: in relevance to the hypotensive action by oral administration, J Pharmacobiodyn, 9 (1986) 547-553.

172.N. Bromet, S. Courte, Y. Aubert, A. Baune, J. Guillandeux, A pharmacokinetic study of almitrine, Rev Fr Mal Respir, 8 (1980) 145-147.

173.D.B. Campbell, B.H. Gordon, R.M. Ings, Pharmacodynamic and pharmacokinetic interactions of almitrine bismesylate, Rev Mal Respir, 2 Suppl 1 (1985) S39-44.

174.J.A. Ribeiro, D. Pallot, B.H. Gordon, D.J. Pallot, A. Mir, R.M.J. Ings, Y. Evrard, D.B. Campbell, Kinetics of Almitrine Bismesylate and its Metabolites in the Carotid Body and Other Tissues of the Rat, in: Chemoreceptors in Respiratory Control, Springer Netherlands, 1987, pp. 394-407.

175.D.S. McQueen, Y. Evrard, B.H. Gordon, D.B. Campbell, Ganglioglomerular nerves influence responsiveness of cat carotid body chemoreceptors to almitrine, J Auton Nerv Syst, 27 (1989) 57-66.

176.E. Jahnchen, G. Levy, Inhibition of phenylbutazone elimination by its metabolite oxyphenbutazone, Proc Soc Exp Biol Med, 141 (1972) 963-965.

177.I. Yamamoto, I.K. Ho, H.H. Loh, The antagonistic effects of 5-ethyl-5-(3-hydroxy-1-methylbutyl)barbituric acid on pentobarbital narcosis in both naive and tolerant mice, Life Sci, 22 (1978) 11031112.

178.S.A. Stavchansky, W.C. Lubawy, H.B. Kostenbauder, Increase of hexobarbital sleeping time and inhibition of drug metabolism by the major metabolite of diphenylhydantoin, Life Sci, 14 (1974) 1535-1539.
179.M.R. Wright, Implications of chirality on pharmacodynamic modeling, Chirality, 6 (1994) 467-471.

180.W.A. Ritschel, A. Hussain, Review on correlation between pharmacologic response and drug disposition, Methods and findings in experimental and clinical pharmacology, 6 (1984) 627-640.

181.A.W. Kelman, B. Whiting, Modeling of drug response in individual subjects, Journal of pharmacokinetics and biopharmaceutics, 8 (1980) 115-130.

182.W.R. Gillespie, P. Veng-Pedersen, E.J. Antal, J.P. Phillips, A system approach to pharmacodynamics. II: Glyburide pharmacodynamics and estimation of optimal drug delivery, Journal of pharmaceutical sciences, 77 (1988) 48-55.

183.R. Zahler, P. Wachtel, P. Jatlow, R. Byck, Kinetics of drug effect by distributed lags analysis: an application to cocaine, Clinical pharmacology and therapeutics, 31 (1982) 775-782.

184.J.M. van Rossum, J.P. Burgers, Quantitative relationships between dynamics and kinetics of drugs: a systems dynamics approach, Drug Metab Rev, 15 (1984) 365-382.

185.W.A. Colburn, Combined Pharmacokinetic / Pharmacodynamic (PK/PD) Modeling, Journal of clinical Pharmacology, 28 (1988) 769-771.

186.B.E. Dahlstrom, L.K. Paalzow, G. Segre, A.J. Agren, Relation between morphine pharmacokinetics and analgesia, Journal of pharmacokinetics and biopharmaceutics, 6 (1978) 41-53.

187.N. Holford, Holford NHG and Sheiner LB "Understanding the Dose-Effect RelationshipClinical Application of PharmacokineticPharmacodynamic Models", Clin Pharmacokin 6:429-453 (1981)-The Backstory, AAPS J, 13 (2011) 662-664.

188.N.H. Holford, L.B. Sheiner, Kinetics of pharmacologic response, Pharmacology \& therapeutics, 16 (1982) 143-166.

189.E. Fuseau, L.B. Sheiner, Simultaneous modeling of pharmacokinetics and pharmacodynamics with a nonparametric pharmacodynamic model, Clinical pharmacology and therapeutics, 35 (1984) 733-741.

190.J.D. Unadkat, F. Bartha, L.B. Sheiner, Simultaneous modeling of pharmacokinetics and pharmacodynamics with nonparametric kinetic and dynamic models, Clinical pharmacology and therapeutics, 40 (1986) 86-93.

191.G. Segre, Kinetics of interaction between drugs and biological systems, Farmaco Sci, 23 (1968) 907-918.

192.R.L. Galeazzi, L.Z. Benet, L.B. Sheiner, Relationship between the pharmacokinetics and pharmacodynamics of procainamide, Clinical pharmacology and therapeutics, 20 (1976) 278-289. 
193.R. Menasse, P.R. Hedwall, J. Kraetz, C. Pericin, L. Riesterer, A. Sallmann, R. Ziel, R. Jaques, Pharmacological properties of diclofenac sodium and its metabolites, Scand J Rheumatol Suppl, (1978) 5-16.

194.J.W. Faigle, I. Bottcher, J. Godbillon, H.P. Kriemler, E. Schlumpf, W. Schneider, A. Schweizer, H. Stierlin, T. Winkler, A new metabolite of diclofenac sodium in human plasma, Xenobiotica; the fate of foreign compounds in biological systems, 18 (1988) 1191-1197.

195.C.R. Tonussi, S.H. Ferreira, Mechanism of diclofenac analgesia: direct blockade of inflammatory sensitization, European journal of pharmacology, 251 (1994) 173-179.

196.N.L. Dayneka, V. Garg, W.J. Jusko, Comparison of four basic models of indirect pharmacodynamic responses, Journal of pharmacokinetics and biopharmaceutics, 21 (1993) 457-478.

197.V. Garg, W.J. Jusko, Pharmacodynamic modeling of nonsteroidal anti-inflammatory drugs: antipyretic effect of ibuprofen, Clinical pharmacology and therapeutics, 55 (1994) 87-88.

198.D. Verotta, L.B. Sheiner, A general conceptual model for non-steady state pharmacokinetic/pharmacodynamic data, Journal of pharmacokinetics and biopharmaceutics, 23 (1995) 1-4.

199.H.C. Porchet, N.L. Benowitz, L.B. Sheiner, Pharmacodynamic model of tolerance: application to nicotine, The Journal of pharmacology and experimental therapeutics, 244 (1988) 231-236.

200.A.M. Persky, N.S. Berry, G.M. Pollack, K.L. Brouwer, Modelling the cardiovascular effects of ephedrine, British journal of clinical pharmacology, 57 (2004) 552-562.

201.S.P. Butcher, J. Liptrot, G.W. Aburthnott, Characterisation of methylphenidate and nomifensine induced dopamine release in rat striatum using in vivo brain microdialysis, Neurosci Lett, 122 (1991) 245-248.

202.Y.L. Hurd, U. Ungerstedt, In vivo neurochemical profile of dopamine uptake inhibitors and releasers in rat caudate-putamen, European journal of pharmacology, 166 (1989) 251-260.

203.M. Gumbleton, S. Oie, D. Verotta, Pharmacokineticpharmacodynamic (PK-PD) modelling in nonsteady-state studies and arterio-venous drug concentration differences, British journal of clinical pharmacology, 38 (1994) 389-400.

204.L.J. Moschitto, D.J. Greenblatt, Concentrationindependent plasma protein binding of benzodiazepines, J Pharm Pharmacol, 35 (1983) 179-180.

205.J.C. Fleishaker, J.P. Phillips, M.G. Eller, R.B. Smith, Pharmacokinetics and pharmacodynamics of alprazolam following single and multiple oral doses of a sustained-release formulation, Journal of clinical pharmacology, 29 (1989) 543-549.

206.M. Sunzel, L. Paalzow, L. Berggren, I. Eriksson, Respiratory and cardiovascular effects in relation to plasma levels of midazolam and diazepam, British journal of clinical pharmacology, 25 (1988) 561569.

207.M. Mattila, Acute and subacute effects of diazepam on human performance: comparison of plain tablet and controlled release capsule, Pharmacol Toxicol, 63 (1988) 369-374.

208.G. Baktir, H.U. Fisch, P. Huguenin, J. Bircher, Triazolam concentration-effect relationships in healthy subjects, Clinical pharmacology and therapeutics, 34 (1983) 195-201.

209.R. Schulz, I.W. Reimann, Practice effect of volunteers in repeated psychometric testing. How to handle this intervening variable in clinical pharmacology studies?, Methods and findings in experimental and clinical pharmacology, 10 (1988) 657-661.

210.J.L. Montastruc, O. Rascol, J.M. Senard, Current status of dopamine agonists in Parkinson's disease management, Drugs, 46 (1993) 384-393.

211.J.B. Hansen, P.M. Sandset, K.R. Huseby, N.E. Huseby, A. Nordoy, Depletion of intravascular pools of tissue factor pathway inhibitor (TFPI) during repeated or continuous intravenous infusion of heparin in man, Thrombosis and haemostasis, 76 (1996) 703-709.

212.E.H. Ellinwood, Jr., A.M. Nikaido, D.G. Heatherly, T.D. Bjornsson, Benzodiazepine pharmacodynamics: evidence for biophase rate limiting mechanisms, Psychopharmacology (Berl), 91 (1987) 168-174.

213.K.L. Goa, R.C. Heel, Zopiclone. A review of its pharmacodynamic and pharmacokinetic properties and therapeutic efficacy as an hypnotic, Drugs, 32 (1986) 48-65.

214.L. Julou, M.C. Bardone, J.C. Blanchard, C. Garret, J.M. Stutzmann, Pharmacological studies on zopiclone, Pharmacology, 27 Suppl 2 (1983) 46-58.

215.R. Elie, J.P. Deschenes, Efficacy and tolerance of zopiclone in insomniac geriatric patients, Pharmacology, 27 Suppl 2 (1983) 179-187.

216.J. Pecknold, R. Wilson, P. le Morvan, Long term efficacy and withdrawal of zopiclone: a sleep laboratory study, Int Clin Psychopharmacol, 5 Suppl 2 (1990) 57-67.

217.G. Paintaud, G. Alvan, S.A. Eckernas, M. Wakelkamp, A. Grahnen, The influence of food intake on the effect of two controlled release formulations of furosemide, Biopharmaceutics \& drug disposition, 16 (1995) 221-232.

218.M. Wakelkamp, G. Alvan, J. Gabrielsson, G. Paintaud, Pharmacodynamic modeling of furosemide tolerance after multiple intravenous 
administration, Clinical pharmacology and therapeutics, 60 (1996) 75-88.

219.P.A. Sjostrom, B.G. Odlind, B.A. Beermann, M. Hammarlund-Udenaes, On the mechanism of acute tolerance to furosemide diuresis, Scand $\mathrm{J}$ Urol Nephrol, 22 (1988) 133-140.

220.H.E. de Wardener. Idiopathic edema: role of diuretic abuse, Kidney international, 19 (1981) 881-891.

221.G. Castaneda-Hernandez, G. Caille, P. du Souich, Influence of drug formulation on drug concentration-effect relationships, Clinical pharmacokinetics, 26 (1994) 135-143.

222.C.H. Kleinbloesem, P. van Brummelen, M. Danhof, H. Faber, J. Urquhart, D.D. Breimer, Rate of increase in the plasma concentration of nifedipine as a major determinant of its hemodynamic effects in humans, Clinical pharmacology and therapeutics, 41 (1987) 26-30.

223.J. van Harten, P. van Brummelen, R.R. Zeegers, M. Danhof, D.D. Breimer, The influence of infusion rate on the pharmacokinetics and haemodynamic effects of nisoldipine in man, British journal of clinical pharmacology, 25 (1988) 709-717.

224.H.L. Elliott, J. Vincent, P.A. Meredith, J.L. Reid, Relationship between plasma prazosin concentration and alpha-antagonism in humans: comparison of conventional and rate-controlled (Oros) formulations, Clinical pharmacology and therapeutics, 43 (1988) 582-587.

225.H.L. Fung, Pharmacokinetic determinants of nitrate action, Am J Med, 76 (1984) 22-26.

226.P.J. Perry, B.M. Pfohl, S.G. Holstad, The relationship between antidepressant response and tricyclic antidepressant plasma concentrations. A retrospective analysis of the literature using logistic regression analysis, Clinical pharmacokinetics, 13 (1987) 381-392.

227.R.C. Smith, G. Vroulis, A. Shvartsburd, R. Allen, N. Lewis, J.C. Schoolar, M. Chojnacki, R. Johnson, $\mathrm{RBC}$ and plasma levels of haloperidol and clinical response in schizophrenia, Am J Psychiatry, 139 (1982) 1054-1056.

228.S. Whitehouse, R.H. Cooper, P.J. Randle, Mechanism of activation of pyruvate dehydrogenase by dichloroacetate and other halogenated carboxylic acids, Biochem J, 141 (1974) 761-774.

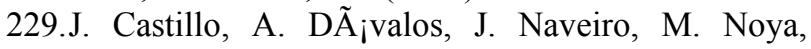
Neuroexcitatory amino acids and their relation to infarct size and neurological deficit in ischemic stroke, Stroke; a journal of cerebral circulation, 27 (1996) 1060-1065.

230.J. Castillo, A. DÃ ¡valos, M. Noya, Progression of ischaemic stroke and excitotoxic aminoacids, The Lancet, 349 (1997) 79-83.

231.M.V. Johnston, W.H. Trescher, A. Ishida, W. Nakajima, Neurobiology of hypoxic-ischemic injury in the developing brain, Pediatric research, 49 (2001) 735-741.

232.A. Zauner, R. Bullock, A.J. Kuta, J. Woodward, H.F. Young, Glutamate release and cerebral blood flow after severe human head injury, Acta neurochirurgica. Supplement, 67 (1996) 40-44.

233.M. Gottlieb, Y. Wang, V.I. Teichberg, Bloodmediated scavenging of cerebrospinal fluid glutamate, Journal of neurochemistry, 87 (2003) $119-126$.

234.C.E. Inturrisi, Pharmacokinetic considerations in analgesic study design, in: M.B. Max, R.K. Portenoy, E. Laska (Eds.) Advances in pain research and therapy: The design of analgesic clinical trials, Raven, New York, 1991, pp. 533-558.

235.D.J. Greenblatt, B.L. Ehrenberg, J. Gunderman, A. Locniskar, J.M. Scavone, J.S. Harmatz, R.I. Shader, Pharmacokinetic and electroencephalographic study of intravenous diazepam, midazolam, and placebo, Clinical pharmacology and therapeutics, 45 (1989) 356-365.

236.R. Koopmans, J. Dingemanse, M. Danhof, G.P. Horsten, C.J. van Boxtel, Pharmacokineticpharmacodynamic modeling of midazolam effects on the human central nervous system, Clinical pharmacology and therapeutics, 44 (1988) 14-22.

237.H. Friedman, D.J. Greenblatt, G.R. Peters, C.M. Metzler, M.D. Charlton, J.S. Harmatz, E.J. Antal, E.C. Sanborn, S.F. Francom, Pharmacokinetics and pharmacodynamics of oral diazepam: effect of dose, plasma concentration, and time, Clinical pharmacology and therapeutics, 52 (1992) 139-150.

238.L.E. van Beijsterveldt, R.J. Geerts, J.E. Leysen, A.A. Megens, H.M. Van den Eynde, W.E. Meuldermans, J.J. Heykants, Regional brain distribution of risperidone and its active metabolite 9-hydroxy-risperidone in the rat, Psychopharmacology (Berl), 114 (1994) 53-62.

239.N.H. Holford, P.E. Coates, T.W. Guentert, S. Riegelman, L.B. Sheiner, The effect of quinidine and its metabolites on the electrocardiogram and systolic time intervals: concentration--effect relationships, British journal of clinical pharmacology, 11 (1981) 187-195.

240.A. Terashima, M. Nakai, T. Hashimoto, T. Kawamata, T. Taniguchi, M. Yasuda, K. Maeda, C. Tanaka, Single-channel activity of the $\mathrm{Ca} 2+-$ dependent $\mathrm{K}+$ channel is modulated by FK506 and rapamycin, Brain research, 786 (1998) 255-258.

241.B. Whiting, N.H. Holford, L.B. Sheiner, Quantitative analysis of the disopyramide concentration-effect relationship, British journal of clinical pharmacology, 9 (1980) 67-75.

242.R.G. McAllister, Jr., E.B. Kirsten, The pharmacology of verapamil. IV. Kinetic and dynamic effects after single intravenous and oral 
doses, Clinical pharmacology and therapeutics, 31 (1982) 418-426.

243.M.J. Reiter, D.G. Shand, E.L. Pritchett, Comparison of intravenous and oral verapamil dosing, Clinical pharmacology and therapeutics, 32 (1982) 711-720.

244.W.A. Colburn, Pharmacokinetic/pharmacodynamic modeling: what it is!, Journal of pharmacokinetics and biopharmaceutics, 15 (1987) 545-555.

245.C.A. Winter, L. Flataker, Reaction thresholds to pressure in edematous hindpaws of rats and responses to analgesic drugs, The Journal of pharmacology and experimental therapeutics, 150 (1965) 165-171.

246.C. Strange, L. Vaughan, C. Franklin, J. Johnson, Comparison of train-of-four and best clinical assessment during continuous paralysis, Am J Respir Crit Care Med, 156 (1997) 1556-1561.

247.P.M. Yate, P.J. Flynn, R.W. Arnold, B.C. Weatherly, R.J. Simmonds, T. Dopson, Clinical experience and plasma laudanosine concentrations during the infusion of atracurium in the intensive therapy unit, British journal of anaesthesia, 59 (1987) 211-217.

248.S.J. Tschida, L.L. Hoey, A. Nahum, K. VanceBryan, Atracurium resistance in a critically Ill patient, Pharmacotherapy, 15 (1995) 533-539.

249.C.J. Parker, J.M. Hunter, A new four-parameter threshold model for the plasma atracurium concentration-response relationship, British journal of anaesthesia, 68 (1992) 548-554.

250.D.J. Greenblatt, B.L. Ehrenberg, K.E. Culm, J.M. Scavone, K.E. Corbett, H.L. Friedman, J.S. Harmatz, R.I. Shader, Kinetics and EEG effects of midazolam during and after 1-minute, 1-hour, and 3hour intravenous infusions, Journal of clinical pharmacology, 44 (2004) 605-611.

251.G.L. Ludbrook, R.N. Upton, C. Grant, A. Martinez, Prolonged dysequilibrium between blood and brain concentrations of propofol during infusions in sheep, Acta anaesthesiologica Scandinavica, 43 (1999) 206-211.

252.J. Kanto, E. Gepts, Pharmacokinetic implications for the clinical use of propofol, Clinical pharmacokinetics, 17 (1989) 308-326.

253.C. Bundgaard, M. Jorgensen, A. Mork, An integrated microdialysis rat model for multiple pharmacokinetic/pharmacodynamic investigations of serotonergic agents, J Pharmacol Toxicol Methods, 55 (2007) 214-223.

254.A. Yassen, E. Olofsen, A. Dahan, M. Danhof, Pharmacokinetic-pharmacodynamic modeling of the antinociceptive effect of buprenorphine and fentanyl in rats: role of receptor equilibration kinetics, The Journal of pharmacology and experimental therapeutics, 313 (2005) 1136-1149.

255.N. Klein, J. Sacher, T. Geiss-Granadia, N. Mossaheb, T. Attarbaschi, R. Lanzenberger, C.
Spindelegger, A. Holik, S. Asenbaum, R. Dudczak, J. Tauscher, S. Kasper, Higher serotonin transporter occupancy after multiple dose administration of escitalopram compared to citalopram: an [123I]ADAM SPECT study, Psychopharmacology (Berl), 191 (2007) 333-339.

256.H.F. Schran, F.L. Tse, S.I. Bhuta, Pharmacokinetics and pharmacodynamics of bromocriptine in the rat, Biopharmaceutics \& drug disposition, 6 (1985) 301311.

257.D.G. Phelan, N.H. Greig, S.I. Rapoport, T.T. Soncrant, High-performance liquid chromatographic assay of bromocriptine in rat plasma and brain, $\mathrm{J}$ Chromatogr, 533 (1990) 264-270.

258.Y.F. Huang, R.N. Upton, A.J. Rutten, L.E. Mather, The hemodynamic effects of intravenous bolus doses of meperidine in conscious sheep, Anesthesia and analgesia, 78 (1994) 442-449.

259.Y.F. Huang, R.N. Upton, L.E. Mather, The pharmacokinetics of meperidine in the myocardium of conscious sheep, Anesthesia and analgesia, 79 (1994) 987-992.

260.E. Perola, L. Cellai, D. Lamba, L. Filocamo, M. Brufani, Long chain analogs of physostigmine as potential drugs for Alzheimer's disease: new insights into the mechanism of action in the inhibition of acetylcholinesterase, Biochim Biophys Acta, 1343 (1997) 41-50.

261.G. Grunder, C. Fellows, H. Janouschek, T. Veselinovic, C. Boy, A. Brocheler, K.M. Kirschbaum, S. Hellmann, K.M. Spreckelmeyer, C. Hiemke, F. Rosch, W.M. Schaefer, I. Vernaleken, Brain and plasma pharmacokinetics of aripiprazole in patients with schizophrenia: an [18F]fallypride PET study, Am J Psychiatry, 165 (2008) 988-995.

262.R. Nagashima, R.A. O'Reilly, G. Levy, Kinetics of pharmacologic effects in man: the anticoagulant action of warfarin, Clinical pharmacology and therapeutics, 10 (1969) 22-35.

263.H.G. Shetty, A.G. Fennerty, P.A. Routledge, Clinical pharmacokinetic considerations in the control of oral anticoagulant therapy, Clinical pharmacokinetics, 16 (1989) 238-253.

264.H.L. Fung, S.C. Sutton, A. Kamiya, Blood vessel uptake and metabolism of organic nitrates in the rat, The Journal of pharmacology and experimental therapeutics, 228 (1984) 334-341.

265.S.C. Sutton, H.L. Fung, Metabolites decrease the plasma clearance of isosorbide dinitrate in rats, Biopharmaceutics \& drug disposition, 5 (1984) 8589.

266.J.E. Blundell, D.B. Campbell, M. Lesham, R. Tozer, Comparison of the time course of the anorectic effect of fenfluramine and amphetamine with drug levels in blood, J Pharm Pharmacol, 27 (1975) 187192. 
267.A.R. Hansen, K.A. Kennedy, J.J. Ambre, L.J. Fischer, Glutethimide poisoning. A metabolite contributes to morbidity and mortality, The New England journal of medicine, 292 (1975) 250-252.

268.A. Morino, M. Sugiyama, Relation between time courses of pharmacological effects and of plasma levels of camazepam and its active metabolites in rats, J Pharmacobiodyn, 8 (1985) 597-606.

269.P. Sandouk, A. Serrie, M. Urtizberea, M. Debray, P. Got, J.M. Scherrmann, Morphine pharmacokinetics and pain assessment after intracerebroventricular administration in patients with terminal cancer, Clinical pharmacology and therapeutics, 49 (1991) 442-448.

270.M. Ekblom, M. Gardmark, M. HammarlundUdenaes, Estimation of unbound concentrations of morphine from microdialysate concentrations by use of nonlinear regression analysis in vivo and in vitro during steady state conditions, Life Sci, 51 (1992) 449-460.

271.M. Gardmark, M. Hammarlund-Udenaes, Delayed antinociceptive effect following morphine-6glucuronide administration in the rat-pharmacokinetic/pharmacodynamic modelling, Pain, 74 (1998) 287-296.

272.M.R. Bouw, M. Gardmark, M. HammarlundUdenaes, Pharmacokinetic-pharmacodynamic modelling of morphine transport across the bloodbrain barrier as a cause of the antinociceptive effect delay in rats--a microdialysis study, Pharmaceutical research, 17 (2000) 1220-1227.

273.M.R. Bouw, R. Xie, K. Tunblad, M. HammarlundUdenaes, Blood-brain barrier transport and brain distribution of morphine-6-glucuronide in relation to the antinociceptive effect in rats-pharmacokinetic/pharmacodynamic modelling, British journal of pharmacology, 134 (2001) 17961804.

274.D. Murdoch, R.N. Brogden, Sustained release nifedipine formulations. An appraisal of their current uses and prospective roles in the treatment of hypertension, ischaemic heart disease and peripheral vascular disorders, Drugs, 41 (1991) 737-779.

275.C. Hocht, C. Di Verniero, J.A. Opezzo, G.F. Bramuglia, C.A. Taira, Pharmacokineticpharmacodynamic (PK-PD) modeling of cardiovascular effects of metoprolol in spontaneously hypertensive rats: a microdialysis study, Naunyn Schmiedebergs Arch Pharmacol, 373 (2006) 310-318.

276.C. Hocht, C. Di Verniero, J.A. Opezzo, C.A. Taira, Pharmacokinetic-pharmacodynamic properties of metoprolol in chronic aortic coarctated rats, Naunyn Schmiedebergs Arch Pharmacol, 370 (2004) 1-8.

277.T.J. van Steeg, J. Freijer, M. Danhof, E.C. de Lange, Pharmacokinetic-pharmacodynamic modelling of $\mathrm{S}(-)$-atenolol in rats: reduction of isoprenaline- induced tachycardia as a continuous pharmacodynamic endpoint, British journal of pharmacology, 151 (2007) 356-366.

278.M. Vakily, F. Khorasheh, F. Jamali, Dependency of gastrointestinal toxicity on release rate of tiaprofenic acid: a novel pharmacokinetic-pharmacodynamic model, Pharmaceutical research, 16 (1999) 123-129.

279.G.D. Clifton, R.A. Blouin, C. Dilea, H.F. Schran, A.E. Hassell, L.M. Gonasun, T.S. Foster, The pharmacokinetics of oral isradipine in normal volunteers, Journal of clinical pharmacology, 28 (1988) 36-42.

280.J. Perez-Urizar, V. Granados-Soto, F.J. FloresMurrieta, G. Castaneda-Hernandez, Pharmacokinetic-pharmacodynamic modeling: why?, Arch Med Res, 31 (2000) 539-545.

281.U.E. Westin, E. Bostrom, J. Grasjo, M. Hammarlund-Udenaes, E. Bjork, Direct nose-tobrain transfer of morphine after nasal administration to rats, Pharmaceutical research, 23 (2006) 565-572.

282.U. Westin, E. Piras, B. Jansson, U. Bergstrom, M. Dahlin, E. Brittebo, E. Bjork, Transfer of morphine along the olfactory pathway to the central nervous system after nasal administration to rodents, Eur $\mathbf{J}$ Pharm Sci, 24 (2005) 565-573.

283.E.H. Cox, C.A. Knibbe, V.S. Koster, M.W. Langemeijer, E.E. Tukker, R. Lange, P.F. Kuks, H.J. Langemeijer, L. Lie-A-Huen, M. Danhof, Influence of different fat emulsion-based intravenous formulations on the pharmacokinetics and pharmacodynamics of propofol, Pharmaceutical research, 15 (1998) 442-448.

284.J.W. Mandema, P. Veng-Pedersen, M. Danhof, Estimation of amobarbital plasma-effect site equilibration kinetics. Relevance of polyexponential conductance functions, Journal of pharmacokinetics and biopharmaceutics, 19 (1991) 617-634.

285.D.E. Duggan, K.F. Hooke, R.M. Noll, K.C. Kwan, Enterohepatic circulation of indomethacin and its role in intestinal irritation, Biochemical pharmacology, 24 (1975) 1749-1754.

286.W.A. Colburn, Simultaneous pharmacokinetic and pharmacodynamic modeling, Journal of pharmacokinetics and biopharmaceutics, 9 (1981) 367-388.

287.S.A. Hooper, R.R. Bowsher, D.C. Howey, Pharmacokinetics and pharmacodyanmics of intravenous regular human insulin, in: P.D. Garzone, W.A. Colburn, M. Motokoff (Eds.) Pharmacokinetics and pharmacodyanmics: Peptides, Peptoids, and Proteins, Harvey Witney Books, Cincinnati, OH, 1991.

288.W.F. Ebling, D.R. Wada, D.R. Stanski, From piecewise to full physiologic pharmacokinetic modeling: applied to thiopental disposition in the rat, Journal of pharmacokinetics and biopharmaceutics, 22 (1994) 259-292. 
289.J.B. Kitts, D.M. Fisher, P.C. Canfell, M.J. Spellman, J.E. Caldwell, T. Heier, M.R. Fahey, R.D. Miller, Pharmacokinetics and pharmacodynamics of atracurium in the elderly, Anesthesiology, 72 (1990) 272-275.

290.F. Donati, F. Varin, J. Ducharme, S.S. Gill, Y. Theoret, D.R. Bevan, Pharmacokinetics and pharmacodynamics of atracurium obtained with arterial and venous blood samples, Clinical pharmacology and therapeutics, 49 (1991) 515-522.

291.F. Donati, S.S. Gill, D.R. Bevan, J. Ducharme, Y. Theoret, F. Varin, Pharmacokinetics and pharmacodynamics of atracurium with and without previous suxamethonium administration, British journal of anaesthesia, 66 (1991) 557-561.

292.P.H. Marathe, J.F. Dwersteg, E.G. Pavlin, R.H. Haschke, D.M. Heimbach, J.T. Slattery, Effect of thermal injury on the pharmacokinetics and pharmacodynamics of atracurium in humans, Anesthesiology, 70 (1989) 752-755.

293.A. Strougo, L. Zuurman, C. Roy, J.L. Pinquier, J.M. van Gerven, A.F. Cohen, R.C. Schoemaker, Modelling of the concentration-effect relationship of THC on central nervous system parameters and hear rate - insight into its mechanisms of action and a tool for clinical research and development of cannabinoids, J Psychopharmacol, 22 (2008) 717726.

294.B.J. Anderson, N.H. Holford, G.A. Woollard, P.L. Chan, Paracetamol plasma and cerebrospinal fluid pharmacokinetics in children, British journal of clinical pharmacology, 46 (1998) 237-243.

295.J.B. Schwartz, D. Verotta, L.B. Sheiner, Pharmacodynamic modeling of verapamil effects under steady-state and nonsteady-state conditions, The Journal of pharmacology and experimental therapeutics, 251 (1989) 1032-1038.

296.M.J. Rumpler, B. Kandala, T.W. Vickroy, G. Hochhaus, R.A. Sams, Pharmacokinetics and pharmacodynamics of glycopyrrolate following a continuous-rate infusion in the horse, $\mathrm{J}$ Vet Pharmacol Ther, (2013).

297.B. Sogaard, H. Mengel, N. Rao, F. Larsen, The pharmacokinetics of escitalopram after oral and intravenous administration of single and multiple doses to healthy subjects, Journal of clinical pharmacology, 45 (2005) 1400-1406.

298.C.R. Pamulapati, R.D. Schoenwald, Ocular pharmacokinetics of a novel tetrahydroquinoline analog in rabbit: compartmental analysis and PK-PD evaluation, Journal of pharmaceutical sciences, 101 414-423.

299.Y.F. Huang, R.N. Upton, W.B. Runciman, IV bolus administration of subconvulsive doses of lignocaine to conscious sheep: relationships between myocardial pharmacokinetics and pharmacodynamics, British journal of anaesthesia, 70 (1993) 556-561.

300.Y.F. Huang, R.N. Upton, D. Zheng, C. McLean, E.C. Gray, C. Grant, The enantiomer-specific kinetics and dynamics of verapamil after rapid intravenous administration to sheep: physiological analysis and modeling, The Journal of pharmacology and experimental therapeutics, 284 (1998) 10481057.

301.N.R. Davis, W.W. Mapleson, A physiological model for the distribution of injected agents, with special reference to pethidine, British journal of anaesthesia, 70 (1993) 248-258.

302.J.L. Gabrielsson, P. Johansson, U. Bondesson, M. Karlsson, L.K. Paalzow, Analysis of pethidine disposition in the pregnant rat by means of a physiological flow model, Journal of pharmacokinetics and biopharmaceutics, 14 (1986) 381-395.

303.S. Bjorkman, D.R. Wada, D.R. Stanski, W.F. Ebling, Comparative physiological pharmacokinetics of fentanyl and alfentanil in rats and humans based on parametric single-tissue models, Journal of pharmacokinetics and biopharmaceutics, 22 (1994) 381-410.

304.T.C. Krejcie, J.A. Jacquez, M.J. Avram, C.U. Niemann, C.A. Shanks, T.K. Henthorn, Use of parallel Erlang density functions to analyze firstpass pulmonary uptake of multiple indicators in dogs, Journal of pharmacokinetics and biopharmaceutics, 24 (1996) 569-588.

305.M.S. Roberts, J.D. Donaldson, M. Rowland, Models of hepatic elimination: comparison of stochastic models to describe residence time distributions and to predict the influence of drug distribution, enzyme heterogeneity, and systemic recycling on hepatic elimination, Journal of pharmacokinetics and biopharmaceutics, 16 (1988) 41-83.

306.W.J. Beek, K.M.K. Muttzall, Transport Phenomena, 2nd ed., Wiley, London, 2000.

307.E.J. Ariens, Stereochemistry, a basis for sophisticated nonsense in pharmacokinetics and clinical pharmacology, European Journal of Clinical Pharmacology, 26 (1984) 663-668.

308.A. Patat, F. le Coz, C. Dubruc, JM Gandon, G. Durrieu, I. Cimarosti, S. Jezequel, O. Curet, I. Zieleniuk, H. Allain, P. Rosenzweig, Pharmacodynamics and pharmacokinetics of two dose regimens of befloxatone, a new reversible and selective monoamine oxidase inhibitor, at steady state in healthy volunteers, Journal of clinical pharmacology, 36 (1996) 216-229.

309.A.J. Jenkins, R.M. Keenan, J.E. Henningfield, E.J. Cone, Correlation between pharmacological effects and plasma cocaine concentrations after smoked administration, Journal of analytical toxicology, 26 (2002) 382-392. 
310.S.M. Evans, E.J. Cone, J.E. Henningfield, Arterial and venous cocaine plasma concentrations in humans: relationship to route of administration, cardiovascular effects and subjective effects, The journal of pharmacology and experimental therapeutics, 279 (1996) 1345-1356.

311.D.R. Mould, T.M. DeFeo, S. Reele, G. Milla, R. Limjuco, T. Crews, N. Choma, I.H. Patel, Simultaneous modeling of the pharmacokinetics and pharmacodynamics of midazolam and diazepam, Clinical pharmacology and therapeutics, 58 (1995) $35-43$.

312.M. Buhrer, P.O. Maitre, C. Crevoisier, D.R. Stanski, Electroencephalographic effects of benzodiazepines. II. Pharmacodynamic modeling of the electroencephalographic effects of midazolam and diazepam, Clinical pharmacology and therapeutics, 48 (1990) 555-567.

313.E. Bellissant, J.F. Giudicelli, Pharmacokineticpharmacodynamic model for fantofarone cardiac and brachial haemodynamic effects in healthy volunteers, British journal of clinical pharmacology, 48 (1999) 801-810.

314.J.R. Woodworth, D.C. Howey, R.R. Bowsher, Establishment of time-action profiles for regular and NPH insulin using pharmacodynamic modeling, Diabetes care, 17 (1994) 64-69.

315.L. Carlucci, K.H. Song, H.I. Yun, H.J. Park, K.W. Seo, M. Giorgi, Pharmacokinetics and pharmacodynamics (PK/PD) or irbesartan in Beagle dogs after oral administration at two dose rates, Polish journal of veterinary sciences, 16 (2013) 555561.

316.E. Bellissant, J.F. Giudicelli, Pharmacokineticpharmacodynamic model for perindoprilat regional haemodynamic effects in healthy volunteers and in congestive heart failure patients, The journal of clinical pharmacology, 52 (2001) 25-33.

317.M. A. Evans, C.A. Shanks, K. F. Brown ,E. J. Triggs, Pharmacokinetic and pharmacodynamic modelling with pancuronium, Eur J Clin Pharmacol, 26 (1984) 243-250.

318.H. Takahashi, H. Ogata, K. Kashiwada, M. Ohira, K. Someya, Dosing rate-dependent relationship between propranolol plasma concentration and $\square$ Blockade, The journal of pharmacology and experimental therapeutics, 265 (1993) 681-689.

319.G. Paintaud, G. Alvan, E. Berninger, L.L. Gustafsson, E. Idrizbegovic, K.K. Karlsson, M. Wakelkamp, The concentration-effect relationship of quinine-induced hearing impairment, Clinical pharmacology and therapeutics, 55 (1994) 317 323.

320.K.M. Koch, M. Liu, I.M. Davis, S. Shaw, Y. Yin, Pharmacokinetics and pharmacodynamics of ranitidine in renal impairment, European journal of clinical pharmacology, 52 (1997) 229-234.
321.J.B. Schwartz, D. Verotta, L.B. Sheiner, Pharmacodynamic modeling of verapamil effects under steady-state and nonsteady-state conditions, The journal of pharmacology and experimental therapeutics, 251 (1989) 1032-1038.

322.E. Bellissant, J.F. Giudicelli, Pharmacokineticpharmacodynamic model relating zabiciprilat plasma concentrations to brachial and femoral haemodynamic effects in normotensive volunteers, British journal of clinical pharmacology, 46 (1998) 383-393.

323.N.E. Buss, G. Renwick, Blood pressure changes and sympathetic functions in rats given cyclohexylamine by intravenous infusion, Toxicology and applied pharmacology, 115 (1992) 211-215.

324.M. Eichelbaum, J.H. Hengstmann, H.D. Rost, T. Brecht, H.J. Dengler, Pharmacokinetics, cardiovascular and metabolic actions of cyclohexylamine in man, Archives of toxicology, 31 (1974) 243-264.

325.H.C. Porchet, N.L. Benowitz, L.B. Sheiner, Pharmacodynamic Model of Tolerance: Application to Nicotine, The journal of pharmacology and experimental therapeutics, 244 (1988) 231-236.

326.C.J. Hull, H.B. Van Beem, K. McLeod, A. Sibbald, M.J. Watson, A pharmacodynamic model for pancuronium, British journal of anaesthesia, 50 (1978) 1113-1123.

327.S. Kahkonen, Propranolol in alcoholic patients, German journal of psychiatry, 2 (1999) 12-18.

328.H.J. Lemmens, J.B. Dyck, S.L. Shafer, D.R. Stanski, Pharmacokinetic-pharmacodynamic modeling in drug development: Application to the investigational opioid trefentanil, Clinical pharmacology and therapeutics, 56 (1994) 261-271.

329.W. J. Jusko, H.C. Ko, W.F., Ebling. Convergence of direct and indirect pharmacodynamics response models. J Pharm Biopharm, 23(1995) 5-8.

330.N.L. Dayneka, V. Garg, W.J. Jusko, Comparison of four basic models of indirect pharmacodynamic responses, J Pharmacokinet Biopharm., 21 (1993) 457-478.

331.W.J. Jusko, H.C. Ko, Physiologic indirect response models characterize diverse types of pharmacodynamics effects, Clin Pharm Ther, 56 (1994) 406-419.

332.A. Sharma, W.J. Jusko, Characterization of four basic models of indirect pharmacodynamics responses. J Pharmacokinet Biopharm, 24 (1996) 611-635.

333.A. Sharma, W.J. Jusko, Characteristics of indirect pharmacodynamics models and applications to clinical drug response, Br J Clin Pharmacol, 45 (1998) 229-239.

334.S. Antila, M. Kivikko, L. Lehtonen, J. Eha, A. Heikkilä, P. Pohjanjousi, PJ Pentikäinen, Pharmacokinetics of levosimendan and its 
circulating metabolites in patients with heart failure after an extended continuous infusion of levosimendan. Br J Clin Pharmacol, 57 (2004) 412415.

335.E. Bellisant, V. Sebille, G. Paintaud. Methodological issues in pharmacokinetic-pharmacodynamic modelling. Clin. Pharmacokin 1998; 35(2): 151-165.

336.R.N. Upton, D.R. Mould. Basic concepts in population modeling, simulation, and model-based drug development: Part 3-Introduction to Pharmacodynamic Modeling Methods. CPT Pharmacometrics Syst Pharmacol 2014; Jan 2; 3:e88.

337.S. Yamazaki, J. Skaptason, D. Romero, J.H. Lee, H.Y. Zou, J.G. Christensen, J.R. Koup, B. J. Smith, T. Koudriakova, Pharmacokineticpharmacodynamic modeling of biomarker response and tumor growth inhibition to an orally available cmet kinase inhibitor in human tumor xenograft mouse models, Drug Metabolism and Distribution 2008; 36: 1267-1274.

338.D. Groenendaal, J. Freijer, D. de Mik, M.R. Bouw, M. Danhof, ECM de Lange, Influence of biophase distribution and P-glycoprotein interaction on pharmacokinetic-pharmacodynamic modelling of the effects of morphine on the EEG, British journal of pharmacology, 2007; 151: 713-720.

339.C. Chen, G.M. Pollack, Altered Disposition and Antinociception of [D-Penicillamine ${ }^{2,5}$ ] Enkephalin in mdrla-Gene-Deficient Mice, The Journal of Pharmacology and Experimental Therapeutics 1998; 287: 545-552.

340.E. Bellissant, ; N.P. Chau, C. Thuillez, C. Gerbeau, C. Richard, J.F. Giudicelli, Pharmacokineticpharmacodynamic model relating spiraprilat plasma concentrations to systemic and regional hemodynamic effects in congestive heart failure, Journal of Cardiovascular Pharmacology. 1997; 30: 253-260. 


\begin{tabular}{|c|c|c|c|c|c|c|c|}
\hline Drug name & $\begin{array}{l}\text { Drug /Class } \\
\text { (Indication) }\end{array}$ & $\begin{array}{c}\text { Population / } \\
\text { species studied } \\
\text { (comorbidities) }\end{array}$ & $\begin{array}{c}\text { Route of } \\
\text { Administration }\end{array}$ & Proposed mechanism & $\begin{array}{l}\text { Effect(s) } \\
\text { measured }\end{array}$ & $\begin{array}{c}\text { Site of drug } \\
\text { concentration measure }\end{array}$ & Reference \\
\hline $\begin{array}{l}\text { Alpha-human atrial } \\
\text { natriuretic peptide }\end{array}$ & Peptide drug & Rats & $\begin{array}{c}\text { 6-12 } \mu \mathrm{g} / \mathrm{kg} \text { iv infusion } \\
\text { over } 60 \mathrm{~min}\end{array}$ & $\begin{array}{l}\text { Site of action, for } \\
\text { diuretic effect, must be } \\
\text { in a tissue or site other } \\
\text { than the blood vessels. }\end{array}$ & $\begin{array}{c}\text { Diuretic effect } \\
(\%)\end{array}$ & $\begin{array}{l}\text { Plasma concentration } \\
\text { (ng/mL) } \alpha \text {-hANP }\end{array}$ & {$[11]$} \\
\hline Aripiprazole & $\begin{array}{c}\text { Atypical } \\
\text { antipsychotic }\end{array}$ & $\begin{array}{l}18 \text { humans } \\
\text { (healthy) }\end{array}$ & $\begin{array}{c}2,5,10,30 \mathrm{mg} \text { single } \\
\text { po doses }\end{array}$ & $\begin{array}{l}\text { Limited access to the } \\
\text { site of action due to the } \\
\text { brain-blood barrier and } \\
\text { transporters molecules } \\
\text { on the barrier }\end{array}$ & $\begin{array}{l}\text { Dopamine } \\
\text { receptor } \\
\text { occupancy } \\
(\%)\end{array}$ & $\begin{array}{l}\text { Plasma concentration } \\
\text { (ng/mL) of aripiprazole }\end{array}$ & [12] \\
\hline Astragaloside IV & $\begin{array}{l}\text { Anti-inflammatory } \\
\text { and } \\
\text { immunoregulatory } \\
\text { (Traditional } \\
\text { Chinese Medicine) }\end{array}$ & Rats & $\begin{array}{c}20 \mathrm{mg} / \mathrm{kg} \\
\text { Astragaloside IV } \\
\text { Atractylenolide I } 2.165 \\
\mathrm{mg} / \mathrm{kg} \text { and } 116.9 \\
\mathrm{mg} / \mathrm{kg} \text { Prim-O- } \\
\text { glucosylcimifugin via } \\
\text { intragastric lavage }\end{array}$ & $\begin{array}{l}\text { Disequilibrium between } \\
\text { effect site and central } \\
\text { compartment }\end{array}$ & $\begin{array}{l}\text { Spleen cell } \\
\text { growth rate }\end{array}$ & $\begin{array}{l}\text { Plasma concentration } \\
(\mathrm{ng} / \mathrm{mL})\end{array}$ & [13] \\
\hline $\begin{array}{c}(+/-) \\
\text { Atenolol }\end{array}$ & $\begin{array}{l}\text { Beta-1 Selective } \\
\text { Beta-Blocker }\end{array}$ & 10 rats & $\begin{array}{l}\text { Immediate release } \\
\text { pellets } 16 \mathrm{mg} / \mathrm{kg} \text { po } \\
\text { single dose }\end{array}$ & $\begin{array}{l}\text { Disequilibrium between } \\
\text { effect site and central } \\
\text { compartment }\end{array}$ & $\begin{array}{l}\text { Change in } \\
\text { Systolic blood } \\
\text { pressure } \\
(\mathrm{mmHg}) \\
\end{array}$ & $\begin{array}{l}\text { Atenolol concentration } \\
\qquad(\mu \mathrm{g} / \mathrm{mL})\end{array}$ & {$[14]^{*}$} \\
\hline Atracurium & $\begin{array}{l}\text { Neuromuscular } \\
\text { blocking agent }\end{array}$ & $\begin{array}{l}10 \text { humans } \\
\text { (critically ill } \\
\text { with acute } \\
\text { respiratory } \\
\text { distress) } \\
\end{array}$ & $\begin{array}{c}1 \mathrm{mg} / \mathrm{kg} \text { iv bolus } \\
\text { followed by } 1 \mathrm{mg} / \mathrm{kg} / \mathrm{hr} \\
\text { for } 72 \mathrm{hrs}\end{array}$ & $\begin{array}{l}\text { Lag time between } \\
\text { concentration and } \\
\text { effect, effect may not } \\
\text { begin until } 80 \% \text { of } \\
\text { receptors are occupied }\end{array}$ & $\begin{array}{c}\text { Train of four } \\
\text { count as index } \\
\text { of therapeutic } \\
\text { effect }\end{array}$ & $\begin{array}{l}\text { Plasma atracurium } \\
\text { concentration }(\mu \mathrm{g} / \mathrm{mL})\end{array}$ & {$[15]$} \\
\hline Azithromycin & $\begin{array}{l}\text { Macrolide } \\
\text { antibiotic }\end{array}$ & Rats & $\begin{array}{l}40,100 \mathrm{mg} / \mathrm{kg} / \mathrm{h} \text { iv } \\
\text { over } 90 \mathrm{~min}\end{array}$ & $\begin{array}{l}\text { Delayed distribution in } \\
\text { the effect site, } \\
\text { potassium channels on } \\
\text { ventricular myocytes }\end{array}$ & $\begin{array}{l}\text { Change in QT } \\
\text { interval } \\
(\mathrm{msec})\end{array}$ & $\begin{array}{l}\text { Plasma concentration of } \\
\text { azithromycin }(\mu \mathrm{g} / \mathrm{mL})\end{array}$ & {$[16]$} \\
\hline $\begin{array}{c}(+/-) \\
\text { Baclofen }\end{array}$ & $\begin{array}{l}\text { Skeletal muscle } \\
\text { relaxant }\end{array}$ & Mice & $\begin{array}{l}1-3 \mathrm{mg} / \mathrm{kg} \\
\text { intraperitoneally }\end{array}$ & $\begin{array}{l}\text { 2- compartment open } \\
\text { model of effect }\end{array}$ & $\begin{array}{l}\text { Antinocicepti } \\
\text { ve effect } \\
\text { (\% MPE) }\end{array}$ & $\begin{array}{c}\text { Baclofen blood } \\
\text { concentration }(\mu \mathrm{g} / \mathrm{mL})\end{array}$ & {$[17]$} \\
\hline Befloxatone & $\begin{array}{l}\text { Reversible and } \\
\text { selective MAO } \\
\text { inhibitor }\end{array}$ & $\begin{array}{l}12 \text { humans } \\
\text { (healthy) }\end{array}$ & $\begin{array}{l}5 \mathrm{mg} \text { po twice daily or } \\
10 \mathrm{mg} \text { po once daily }\end{array}$ & $\begin{array}{l}\text { Compartment effect or } \\
\text { an indirect response }\end{array}$ & $\begin{array}{l}\% \text { of DHPG } \\
\text { decrease from } \\
\text { baseline }\end{array}$ & $\begin{array}{l}\text { Plasma concentration of } \\
\text { befloxatone }(\mathrm{ng} / \mathrm{ml})\end{array}$ & [298] \\
\hline Benidipine & $\begin{array}{c}\text { Dihydropyridine } \\
\text { calcium channel } \\
\text { blocker }\end{array}$ & Rats & $1 \mathrm{mg} / \mathrm{kg}$ po & $\begin{array}{l}\text { Effect-compartment } \\
\text { model }\end{array}$ & $\begin{array}{l}\text { Change in } \\
\text { blood } \\
\text { pressure }(\%) \\
\end{array}$ & $\begin{array}{l}\text { Plasma concentration of } \\
\text { benidipine }(\mathrm{ng} / \mathrm{mL})\end{array}$ & {$[18]$} \\
\hline
\end{tabular}


J Pharm Pharm Sci (www.cspsCanada.org) 17(1) 34 - 91, 2014

\begin{tabular}{|c|c|c|c|c|c|c|c|}
\hline Bromocriptine & Dopamine agonist & Rats & $2.5,10 \mathrm{mg} / \mathrm{kg}$ ip & $\begin{array}{c}\text { Equilibration delay } \\
\text { between concentrations } \\
\text { in the brain and } \\
\text { concentration in plasma }\end{array}$ & $\begin{array}{l}\text { Number of } \\
\text { rotations } \\
(/ 15 \mathrm{~min})\end{array}$ & $\begin{array}{l}\text { Plasma bromocriptine } \\
\text { concentration }(\mathrm{ng} / \mathrm{mL})\end{array}$ & [19] \\
\hline Bumetanide & Loop Diuretic & $\begin{array}{l}3 \text { humans } \\
\text { (healthy) }\end{array}$ & $1 \mathrm{mg}$ IR tablet po & Absorption rate & $\begin{array}{l}\text { Urine flow } \\
\text { rate }(\mathrm{ml} / \mathrm{h})\end{array}$ & $\begin{array}{l}\text { Plasma concentration of } \\
\text { bumetanide }(\mathrm{ng} / \mathrm{ml})\end{array}$ & {$[20]^{*}$} \\
\hline Bunazosin & Alpha-1 blocker & $\begin{array}{l}9 \text { humans (renal } \\
\text { insufficiency) } \\
11 \text { humans } \\
\text { (healthy) }\end{array}$ & $3 \mathrm{mg}$ po (single dose) & $\begin{array}{c}\text { Delay in the } \\
\text { equilibration between } \\
\text { the plasma } \\
\text { concentration and } \\
\text { concentration at the } \\
\text { effect site }\end{array}$ & $\begin{array}{c}\Delta \mathrm{SBP} \\
(\mathrm{mmHg}) \\
\Delta \mathrm{DBP} \\
(\mathrm{mmHg}) \\
\Delta \mathrm{HR}(\mathrm{bpm})\end{array}$ & $\begin{array}{c}\text { Plasma bunazosin } \\
\text { concentration }(\mathrm{ng} / \mathrm{mL})\end{array}$ & [21] \\
\hline $\begin{array}{c}(+/-) \\
\text { Buprenorphine }\end{array}$ & Opioid analgesic & 4 Rats & $\begin{array}{c}8 \mu \mathrm{g} / \mathrm{kg} \text { iv over } 20 \\
\text { seconds }\end{array}$ & $\begin{array}{c}\text { Kinetics of target site } \\
\text { distribution and } \\
\text { receptor } \\
\text { association/dissociation } \\
\text { kinetics }\end{array}$ & $\begin{array}{l}\text { Change in } \\
\text { latency in } \\
\text { cerebellum, } \\
\text { the rest of } \\
\text { brain, and } \\
\text { specific } \\
\text { binding site } \\
(\mathrm{sec})\end{array}$ & $\begin{array}{c}\text { Concentration of } \\
\text { buprenorphine }(\mathrm{ng} / \mathrm{mL})\end{array}$ & {$[22]$} \\
\hline$(+/-)$ Candesartan & $\begin{array}{l}\text { Angiotensin II } \\
\text { receptor blocker }\end{array}$ & $\begin{array}{l}12 \text { humans } \\
\text { (healthy) }\end{array}$ & $8 \mathrm{mg}$ po & $\begin{array}{l}\text { Distributional delay } \\
\text { between the } \\
\text { concentrations in } \\
\text { plasma and effect site }\end{array}$ & $\begin{array}{l}\text { Pharmacodyn } \\
\text { amics (areas } \\
\text { under the } \\
\text { effect time } \\
\text { profile: DR- } \\
\text { 1) }\end{array}$ & $\begin{array}{l}\text { Pharmacokinetics } \\
\text { (concentration } \\
\text { equivalents: } \mathrm{nKi} \text { ) }\end{array}$ & {$[22]$} \\
\hline$(+/-)$ Candesartan & $\begin{array}{l}\text { Angiotensin II } \\
\text { receptor blocker }\end{array}$ & $\begin{array}{l}12 \text { humans } \\
\text { (healthy) }\end{array}$ & $\begin{array}{c}\text { 4, 8, } 16 \text { mg po (single } \\
\text { doses) }\end{array}$ & $\begin{array}{c}\text { Slow off-rate of } \\
\text { candesartan from the } \\
\text { receptor site }\end{array}$ & Diastolic BP & $\begin{array}{l}\text { Plasma concentration of } \\
\text { candesartan }(\mathrm{ng} / \mathrm{mL})\end{array}$ & {$[23]$} \\
\hline Cibenzoline & $\begin{array}{c}\text { Class I } \\
\text { antiarrhythmic } \\
\text { agent }\end{array}$ & $\begin{array}{l}6 \text { humans } \\
\text { (healthy) }\end{array}$ & $\begin{array}{c}100 \mathrm{mg} \text { iv over } 20 \\
\text { minutes }\end{array}$ & $\begin{array}{c}\text { Lag between drug } \\
\text { concentration and effect }\end{array}$ & $\begin{array}{c}\text { QRS } \\
\text { prolongation } \\
(\% \text { increase } \\
\text { from baseline }) \\
\end{array}$ & $\begin{array}{l}\text { Cibenzoline plasma } \\
\text { concentration }(\mathrm{ng} / \mathrm{mL})\end{array}$ & {$[24]$} \\
\hline Clarithromycin & $\begin{array}{l}\text { Macrolide } \\
\text { antibiotic }\end{array}$ & Rats & $\begin{array}{l}6.6,21.6,43.2 \mathrm{mg} / \mathrm{kg} / \mathrm{h} \\
\text { iv over } 90 \mathrm{~min}\end{array}$ & $\begin{array}{l}\text { Delayed distribution in } \\
\text { the effect site, } \\
\text { potassium channels on } \\
\text { ventricular myocytes }\end{array}$ & $\begin{array}{l}\text { Change in QT } \\
\text { interval } \\
(\mathrm{msec})\end{array}$ & $\begin{array}{l}\text { Plasma concentration of } \\
\text { clarithromycin }(\mu \mathrm{g} / \mathrm{mL})\end{array}$ & {$[16]$} \\
\hline
\end{tabular}


J Pharm Pharm Sci (www.cspsCanada.org) 17(1) 34 - 91, 2014

\begin{tabular}{|c|c|c|c|c|c|c|c|}
\hline Clonidine & $\begin{array}{c}\text { Alpha2- adrenergic } \\
\text { agonist }\end{array}$ & $\begin{array}{l}10 \text { humans } \\
\text { (healthy) }\end{array}$ & $200 \mu \mathrm{g}$ ро & $\begin{array}{l}\text { Delay between drug } \\
\text { receptor binding and } \\
\text { observed effects }\end{array}$ & $\begin{array}{c}\text { Rm threshold } \\
(\mathrm{mA}) \\
\text { MAP } \\
(\mathrm{mmHg})\end{array}$ & $\begin{array}{l}\text { Clonidine concentration } \\
\qquad(\mathrm{ng} / \mathrm{mL})\end{array}$ & {$[25]$} \\
\hline Cocaine & Drug of abuse & 7 humans & $\begin{array}{l}\text { Smoked doses }(10,20, \\
\text { and } 40 \mathrm{mg})\end{array}$ & $\begin{array}{l}\text { Lag between blood } \\
\text { concentration and effect } \\
\text { due to drug being } \\
\text { transported through } \\
\text { tissues in the effect } \\
\text { compartment }\end{array}$ & $\begin{array}{l}\text { Heart rate } \\
\text { mean change } \\
(\mathrm{BPM}) \text { and } \\
\text { pupil diameter } \\
\text { mean changr } \\
(\mathrm{mm})\end{array}$ & $\begin{array}{c}\text { Plasma cocaine } \\
\text { concentration }(\mathrm{ng} / \mathrm{ml})\end{array}$ & {$[299]^{*}$} \\
\hline Cocaine & Drug of abuse & $\begin{array}{l}9 \text { humans } \\
\text { (healthy) }\end{array}$ & $\begin{array}{l}\text { Smoked dose }(12.5,25 \\
\text { and } 50 \mathrm{mg}) \text { and i.v. } \\
\text { doses }(8,16,32 \mathrm{mg})\end{array}$ & $\begin{array}{l}\text { Rapid distribution of } \\
\text { drug to the brain }\end{array}$ & $\begin{array}{l}\text { Mean change } \\
\text { in systolic and } \\
\text { diastolic } \\
\text { pressure } \\
\text { (BPM) and } \\
\text { ratings of } \\
\text { stimulated, } \\
\text { high or drug } \\
\text { liking }\end{array}$ & $\begin{array}{l}\text { Arterial plasma cocaine } \\
\text { concentration }(\mathrm{ng} / \mathrm{ml})\end{array}$ & {$[300]^{*}$} \\
\hline Cyclosporin A & $\begin{array}{c}\text { Calcineurin } \\
\text { Inhibitor } \\
\text { Immunosuppressan } \\
\mathrm{t}\end{array}$ & Rats & $\begin{array}{c}\text { Sandimmune single } \\
\text { injection } 1 \text { and } \\
10 \mathrm{mg} / \mathrm{mL}\end{array}$ & $\begin{array}{l}\text { Delay in distribution of } \\
\text { the drug to effect site }\end{array}$ & $\begin{array}{l}\text { Calcineurin } \\
\text { inhibition (\%) }\end{array}$ & $\begin{array}{c}\text { Cyclosporin A } \\
\text { concentration }(\mathrm{ng} / \mathrm{mL})\end{array}$ & {$[26]$} \\
\hline Cysteamine & $\begin{array}{l}\text { Cysteine depleting } \\
\text { agent }\end{array}$ & $\begin{array}{l}11 \text { humans } \\
\text { (nephropathic } \\
\text { cystinosis) }\end{array}$ & $\begin{array}{l}\text { Varied for each person, } \\
\text { QID }\end{array}$ & $\begin{array}{l}\text { Lag time between drug } \\
\text { concentration and effect }\end{array}$ & $\begin{array}{l}\text { White blood } \\
\text { cell cysteine } \\
\text { concentration } \\
\text { (nmol } 1 / 2 \\
\text { cysteine per } \\
\text { mg protein) }\end{array}$ & $\begin{array}{l}\text { Mean cysteamine } \\
\text { concentration }(\mu \mathrm{M})\end{array}$ & {$[27]$} \\
\hline D-amphetamine & Stimulant & 22 rats & $\begin{array}{c}1.5 \mathrm{mg} / \mathrm{kg} \\
\text { D-amfetamine base IR }\end{array}$ & $\begin{array}{l}\text { Delay of drug crossing } \\
\text { the BBB and entering } \\
\text { the striatal nerve } \\
\text { terminals before } \\
\text { releassing dopamine to } \\
\text { produce the functional } \\
\text { outcome }\end{array}$ & $\begin{array}{l}\text { Striatal } \\
\text { dopamine } \\
\text { concentration } \\
\text { (\% of } \\
\text { baseline) and } \\
\text { Locomotor } \\
\text { activity }\end{array}$ & $\begin{array}{l}\text { Plasma amphetamine } \\
\text { (ng/mL) }\end{array}$ & {$[28]^{*}$} \\
\hline $\begin{array}{l}\text { [D- } \\
\text { Penicillamine } \\
\text { kephalin (DPDPE) }\end{array}$ & $\begin{array}{c}\text { Opioid } \\
\text { pentapeptide }\end{array}$ & $\begin{array}{l}\text { Mice }[\mathrm{FVB} \text { and } \\
\operatorname{mdr} 1 \mathrm{a}(2 / 2)]\end{array}$ & $10 \mathrm{mg} / \mathrm{kg}$ i.v. & $\begin{array}{l}\text { The site of action in } \\
\text { both strains was } \\
\text { pharmacologically } \\
\text { distinct from the central } \\
\text { compartment }\end{array}$ & $\begin{array}{l}\text { Antinocicepti } \\
\text { on (\% MPR) }\end{array}$ & $\begin{array}{c}\text { Dose normalized blood } \\
\text { concentration (ng/ml per } \\
\mathrm{mg} / \mathrm{kg})\end{array}$ & [329] \\
\hline
\end{tabular}


J Pharm Pharm Sci (www.cspsCanada.org) 17(1) 34 - 91, 2014

\begin{tabular}{|c|c|c|c|c|c|c|c|}
\hline Diazepam & Benzodiazepine & $\begin{array}{l}12 \text { humans } \\
\text { (healthy) }\end{array}$ & $\begin{array}{c}0.1 \mathrm{mg} / \mathrm{kg} \text { and } 0.2 \\
\mathrm{mg} / \mathrm{kg} \text { iv infusion (four } \\
\text { separate occasions) }\end{array}$ & None described & $\begin{array}{l}\text { Digital } \\
\text { Symbol } \\
\text { Substitution } \\
\text { Test Score } \\
\text { (number } \\
\text { correct) } \\
\end{array}$ & $\begin{array}{l}\text { Plasma concentration of } \\
\text { Diazepam }(\mathrm{ng} / \mathrm{ml})\end{array}$ & {$[301]^{*}$} \\
\hline Diazepam & Benzodiazepine & $\begin{array}{l}3 \text { humans } \\
\text { (healthy) }\end{array}$ & $\begin{array}{l}15,30, \text { and } 50 \mathrm{mg} \text { iv } \\
\text { infusion at } 10 \mathrm{mg} / \mathrm{min}\end{array}$ & $\begin{array}{c}\text { Disequilibrium } \\
\text { between plasma and } \\
\text { effect compartment }\end{array}$ & $\begin{array}{l}\text { EEG drug } \\
\text { effect }(u V)\end{array}$ & $\begin{array}{l}\text { Plasma concentration of } \\
\text { Diazepam }(\mathrm{ng} / \mathrm{ml})\end{array}$ & {$[302]^{*}$} \\
\hline Diclofenac & $\begin{array}{l}\text { Non-steroidal anti- } \\
\text { inflammatory agent }\end{array}$ & 30 rats & $\begin{array}{c}0.56,1,1.8,3.2,5.6 \\
10 \mathrm{mg} / \mathrm{kg} \text { po }\end{array}$ & $\begin{array}{l}\text { Slow equilibrium } \\
\text { kinetics between } \\
\text { diclofenac } \\
\text { concentration in the } \\
\text { central and effect } \\
\text { compartments }\end{array}$ & $\begin{array}{l}\text { Functionality } \\
\text { index (\%) } \\
\text { (observed } \\
\text { antinociceptiv } \\
\text { e effect) }\end{array}$ & $\begin{array}{l}\text { Blood concentration of } \\
\text { diclofenac }(\mathrm{ng} / \mathrm{mL})\end{array}$ & [29] \\
\hline Diclofenac & $\begin{array}{l}\text { Non-steroidal anti- } \\
\text { inflammatory agent }\end{array}$ & $\begin{array}{l}20 \text { humans } \\
\text { (healthy) }\end{array}$ & $\begin{array}{l}50 \mathrm{mg} \text { and } 100 \mathrm{mg} \\
\text { Diclofenac-Na } \\
\text { effervescent po }\end{array}$ & $\begin{array}{l}\text { Time delay between the } \\
\text { plasma concentrations } \\
\text { of diclofenac and the } \\
\text { effect versus time } \\
\text { profiles }\end{array}$ & $\begin{array}{c}\text { Analgesic } \\
\text { effects using } \\
\text { an } \\
\text { experimental } \\
\text { human pain } \\
\text { model } \\
\end{array}$ & $\begin{array}{l}\text { Blood concentration of } \\
\text { diclofenac }(\mathrm{ng} / \mathrm{mL})\end{array}$ & {$[30]$} \\
\hline Dofetilide & $\begin{array}{l}\text { Antiarrhythmic } \\
\text { agent }\end{array}$ & $\begin{array}{l}10 \text { humans } \\
\text { (healthy) }\end{array}$ & $\begin{array}{c}0.5 \mathrm{mg} \text { iv infusion over } \\
30 \mathrm{~min}\end{array}$ & $\begin{array}{c}\text { Delay of drug } \\
\text { penetration to the active } \\
\text { site }\end{array}$ & QTc (ms) & $\begin{array}{l}\text { Plasma concentration of } \\
\text { dofetilide }(\mathrm{ng} / \mathrm{mL})\end{array}$ & [31] \\
\hline Eptastigmine & $\begin{array}{l}\text { Acetyl- } \\
\text { cholinesterase } \\
\text { inhibitor }\end{array}$ & $\begin{array}{l}8 \text { humans } \\
\text { (healthy) }\end{array}$ & $\begin{array}{c}\begin{array}{c}10,20,30 \mathrm{mg} \text { po single } \\
\text { dose }\end{array} \\
\text {. }\end{array}$ & $\begin{array}{l}\text { Formation of active } \\
\text { metabolites and/or a } \\
\text { slow association to and } \\
\text { dissociation from the } \\
\text { enzyme in red blood } \\
\text { cells }\end{array}$ & $\begin{array}{c}\text { Average } \\
\text { plasma } \\
\text { cholinesterase } \\
\text { inhibition }(\%) \\
\text { Average RBC } \\
\text { cholinesterase } \\
\text { inhibition }(\%)\end{array}$ & $\begin{array}{l}\text { Average eptastigmine } \\
\text { plasma level }(\mathrm{ng} / \mathrm{mL})\end{array}$ & {$[32]$} \\
\hline Escitalopram & $\begin{array}{l}\text { Selective serotonin } \\
\text { reuptake inhibitor }\end{array}$ & Mice & $\begin{array}{c}1 \mathrm{mg} / \mathrm{kg} \text { single sub cut } \\
\text { injection }\end{array}$ & $\begin{array}{l}\text { Slow permeation over } \\
\text { the blood-brain barrier }\end{array}$ & 5-HTP Score & $\begin{array}{c}\text { Escitalopram serum } \\
\text { concentration }(\mathrm{ng} / \mathrm{mL})\end{array}$ & [33] \\
\hline Fantofarone & Calcium antagonist & $\begin{array}{l}6 \text { humans } \\
\text { (healthy) }\end{array}$ & $\begin{array}{l}100 \mathrm{mg} \text { and } 300 \mathrm{mg} \text { po } \\
\text { single dose }\end{array}$ & Effect compartment & $\begin{array}{c}\text { PR Interval } \\
\text { duration (ms) } \\
\text { and Brachial } \\
\text { Artery Flow } \\
(\%) \\
\end{array}$ & $\begin{array}{l}\text { Fantofarone SR } 33671 \\
\text { Concentration }(\mathrm{ng} / \mathrm{ml})\end{array}$ & {$[303]$} \\
\hline $\begin{array}{c}(+/-) \\
\text { Felodipine }\end{array}$ & $\begin{array}{l}\text { Calcium channel } \\
\text { blocker }\end{array}$ & $\begin{array}{l}18 \text { humans (4 } \\
\text { healthy and } 14 \\
\text { with impared } \\
\text { renal function) }\end{array}$ & $\begin{array}{c}10 \text { mg felodipine orally } \\
\text { as steady state }\end{array}$ & $\begin{array}{l}\text { Slow equilibrium } \\
\text { between drug and } \\
\text { receptor }\end{array}$ & $\begin{array}{l}\text { Effect of } \\
\text { Diastolic } \\
\text { Blood } \\
\text { Pressure (\% } \\
\text { reduction) }\end{array}$ & $\begin{array}{c}\text { Plasma Concentration } \\
\text { (nmol/l) }\end{array}$ & [34] \\
\hline
\end{tabular}




\begin{tabular}{|c|c|c|c|c|c|c|c|}
\hline Fenretinide & Synthetic retinoid & $\begin{array}{l}50 \text { children with } \\
\text { neuroblastoma }\end{array}$ & $\begin{array}{c}100-4000 \mathrm{mg} / \mathrm{m}^{2} \text { po } \\
\text { daily for } 28 \text { days }\end{array}$ & $\begin{array}{c}\text { Presence of an effect } \\
\text { compartment (possibly } \\
\text { the liver) }\end{array}$ & $\begin{array}{l}\text { Percentage } \\
\text { reduction in } \\
\text { retinol levels }\end{array}$ & Fenretinide $(\mu \mathrm{M})$ & {$[35]$} \\
\hline$(+/-)$ Fexofenadine & $\mathrm{H}_{1}$-antagonist & $\begin{array}{l}6 \text { humans } \\
\text { (healthy) }\end{array}$ & $60 \mathrm{mg}$ po tablet & $\begin{array}{c}\text { Equilibration delay } \\
\text { between the plasma } \\
\text { concentration and effect } \\
\text { site compartment }\end{array}$ & $\begin{array}{l}\text { QTc interval } \\
\text { in } \\
\text { milliseconds }\end{array}$ & $\begin{array}{c}\text { Fexofenadine } \\
\text { concentration }(\mathrm{ng} / \mathrm{mL})\end{array}$ & [36] \\
\hline$(+/-)$ Flurbiprofen & $\begin{array}{l}\text { Non-steroidal anti- } \\
\text { inflammatory agent }\end{array}$ & 8 rats & $\begin{array}{l}10 \mathrm{mg} / \mathrm{kg} \text { gastric } \\
\text { intubation sustained } \\
\text { release granules }\end{array}$ & $\begin{array}{l}\text { Intestinal permeability } \\
\text { changes by the } \\
\text { sustained release } \\
\text { formulation is not only } \\
\text { due to systemic } \\
\text { availability of the } \\
\text { NSAID since it may be } \\
\text { also resulted from } \\
\text { continuous exposure of } \\
\text { the intestinal tract to the } \\
\text { drug }\end{array}$ & $\begin{array}{l}\text { Change in } \\
\text { intestinal } \\
\text { permeability }\end{array}$ & $\begin{array}{c}\text { S-Flurbiprofen } \\
\text { concentration }(\mu \mathrm{g} / \mathrm{mL})\end{array}$ & {$[37]$} \\
\hline Furosemide & Loop diuretic & $\begin{array}{l}26 \text { humans } \\
\text { (healthy) }\end{array}$ & $60 \mathrm{mg}$ tablet po & Delay of effect & $\begin{array}{l}\text { Diuresis } \\
(\mathrm{mL} / \mathrm{min})\end{array}$ & $\begin{array}{l}\text { Furosemide excretion rate } \\
(\mu \mathrm{g} / \mathrm{min})\end{array}$ & {$[38]^{*}$} \\
\hline Furosemide & Loop diuretic & $\begin{array}{l}4 \text { humans } \\
\text { (healthy) }\end{array}$ & $40 \mathrm{mg}$ IR tablet po & $\begin{array}{l}\text { Inhibition of the } \\
\text { reabsorption of sodium } \\
\text { and chloride at Loop of } \\
\text { Henle was delayed due } \\
\text { to fast absorption } \\
\text { resulting in rapid } \\
\text { excretion }\end{array}$ & $\begin{array}{l}\text { Diuretic rate } \\
\quad(\mathrm{ml} / \mathrm{h})\end{array}$ & $\begin{array}{l}\text { Excretion rate of } \\
\text { furosemide }(\mathrm{mg} / \mathrm{h})\end{array}$ & {$[39]^{*}$} \\
\hline Furosemide & Loop diuretic & $\begin{array}{c}11 \text { humans, } \\
\text { Middle Eastern } \\
\text { Arabs (healthy) } \\
12 \text { humans, } \\
\text { Asian (healthy) } \\
\end{array}$ & $\begin{array}{c}40 \mathrm{mg} \text { tab po single } \\
\text { dose }\end{array}$ & $\begin{array}{l}\text { Delay in drug action/ } \\
\text { delay in equilibrium }\end{array}$ & $\begin{array}{l}\text { Furosemide } \\
\text { excretion rate }\end{array}$ & $\begin{array}{l}\text { Plasma concentration of } \\
\text { furosemide }\end{array}$ & {$[40]^{*}$} \\
\hline Furosemide & Loop diuretic & $\begin{array}{l}8 \text { humans } \\
\text { (healthy) }\end{array}$ & $\begin{array}{c}10 \mathrm{mg} \text { iv infusion over } \\
10 \text { minutes }\end{array}$ & $\begin{array}{l}\text { Delay between } \\
\text { excretion rate and the } \\
\text { diuretic effect }\end{array}$ & $\begin{array}{c}\text { Diuresis } \\
(\mathrm{mL} / \mathrm{min}) \text { and } \\
\text { Natiuresis } \\
(\mathrm{mmol} / \mathrm{min})\end{array}$ & $\begin{array}{l}\text { Furosemide excretion rate } \\
\qquad(\mu \mathrm{g} / \mathrm{min})\end{array}$ & {$[41]^{*}$} \\
\hline Indomethacin & $\begin{array}{l}\text { Non-steroidal anti- } \\
\text { inflammatory agent }\end{array}$ & 6 rats & $\begin{array}{c}10 \text { and } 20 \mathrm{mg} / \mathrm{kg} \text { po } \\
\text { doses }\end{array}$ & $\begin{array}{l}\text { Effect-compartment } \\
\text { model }\end{array}$ & $\begin{array}{c}\text { Mean urinary } \\
{ }^{51} \text { Cr-EDTA } \\
\text { excretion } \\
\end{array}$ & $\begin{array}{l}\text { Indomethacin plasma } \\
\text { concentration }(\mathrm{mg} / \mathrm{L})\end{array}$ & {$[42]$} \\
\hline $\begin{array}{l}\text { Insulin (Regular } \\
\text { and NPH) }\end{array}$ & Peptide hormone & $\begin{array}{l}16 \text { humans } \\
\text { (healthy) }\end{array}$ & $\begin{array}{l}10 \text { Units regular insulin } \\
\text { given subcutaneously } \\
\text { or } 25 \text { Units NPH given } \\
\text { subcutaneously as } \\
\text { single dose }\end{array}$ & $\begin{array}{l}\text { Delay between serum } \\
\text { insulin concentrations } \\
\text { and effect }\end{array}$ & $\begin{array}{c}\text { Glucose } \\
\text { Infusion Rate } \\
(\mathrm{mmol} / \mathrm{min})\end{array}$ & $\begin{array}{c}\text { Insulin serum } \\
\text { concentration }(\mathrm{pmol} / \mathrm{L})\end{array}$ & [304] \\
\hline
\end{tabular}


J Pharm Pharm Sci (www.cspsCanada.org) 17(1) 34 - 91, 2014

\begin{tabular}{|c|c|c|c|c|c|c|c|}
\hline $\begin{array}{c}(+/-) \\
\text { Irbesartan }\end{array}$ & $\begin{array}{l}\text { Angiotensin II } \\
\text { Receptor Blocker }\end{array}$ & 36 humans & $\begin{array}{l}150 \text { or } 300 \mathrm{mg} \text { tablet } \\
\text { po single dose }\end{array}$ & $\begin{array}{l}\text { Vasodilatory effect of } \\
\text { irbesartan on the AT1 } \\
\text { receptor (effect } \\
\text { compartment model) }\end{array}$ & $\begin{array}{l}\text { DBP (mmHg) } \\
\text { SBP (mmHg) }\end{array}$ & $\begin{array}{c}\text { Plasma drug } \\
\text { concentration of } \\
\text { irbesartan }(\mu \mathrm{g} / \mathrm{mL})\end{array}$ & {$[43]$} \\
\hline $\begin{array}{c}(+/-) \\
\text { Irbesartan }\end{array}$ & $\begin{array}{l}\text { Angiotensin II } \\
\text { Receptor Blocker }\end{array}$ & 10 dogs & $\begin{array}{c}2 \mathrm{mg} / \mathrm{kg} \text { or } 5 \mathrm{mg} / \mathrm{kg} \text { po } \\
\text { dose }(2 \text { treatments } 3 \\
\text { weeks apart })\end{array}$ & $\begin{array}{l}\text { Time needed for the } \\
\text { drug distribution from } \\
\text { the central } \\
\text { compartment to AT1 } \\
\text { receptors }\end{array}$ & $\begin{array}{l}\text { Inhibitory } \\
\text { effect on SBP } \\
(\mathrm{mmHg})\end{array}$ & $\begin{array}{c}\text { Plasma drug } \\
\text { concentration of } \\
\text { irbesartan }(\mathrm{ng} / \mathrm{mL})\end{array}$ & {$[305]^{*}$} \\
\hline Isosorbide dinitrate & Antianginal agent & $\begin{array}{c}11 \text { humans } \\
\text { (coronary artery } \\
\text { disease) }\end{array}$ & $\begin{array}{l}2 \mathrm{mg} \text { iv over } 15 \mathrm{~min} \text {, } \\
5 \mathrm{mg} \text { sublingual tablet }\end{array}$ & $\begin{array}{l}\text { Changes in blood } \\
\text { pressure response lag } \\
\text { behind changes in } \\
\text { plasma Isosorbide } \\
\text { dinitrate concentration }\end{array}$ & $\begin{array}{l}\text { Percent } \\
\text { change in } \\
\text { standing } \\
\text { systolic } \\
\text { pressure }\end{array}$ & $\begin{array}{c}\text { Plasma isosorbide } \\
\text { dinitrate concentration } \\
(\mathrm{ng} / \mathrm{mL})\end{array}$ & {$[44]$} \\
\hline $\begin{array}{c}(+/-) \\
\text { Isradipine }\end{array}$ & $\begin{array}{l}\text { Dihydropyridine } \\
\text { Calcium channel } \\
\text { blocker }\end{array}$ & $\begin{array}{l}10 \text { humans } \\
\text { (healthy) }\end{array}$ & $\begin{array}{c}1 \mathrm{mg} \text { iv infusion } \\
5 \mathrm{mg} \text { po solution } \\
5 \mathrm{mg} \text { tablet } \\
10 \mathrm{mg} \text { slow release } \\
\text { formulation }\end{array}$ & $\begin{array}{l}\text { Possible active } \\
\text { metabolite }\end{array}$ & $\begin{array}{l}\text { DBP fall } \\
(\mathrm{mmHg})\end{array}$ & $\begin{array}{l}\text { Concentration of } \\
\text { isradipine }(\mathrm{ng} / \mathrm{mL})\end{array}$ & {$[45]$} \\
\hline$(+/-)$ Itraconazole & Antifungal agent & Rats & $\begin{array}{c}5 \& 40 \mathrm{mg} / \mathrm{kg} 5 \mathrm{~min} \\
\text { infusion }\end{array}$ & $\begin{array}{l}\text { Factors other than } \\
\text { itraconazole determine } \\
\text { the time course for the } \\
\text { inhibition of CYP3A }\end{array}$ & $\begin{array}{c}\text { Hepatic } \\
\text { availability }\end{array}$ & $\begin{array}{c}\text { Itraconazole concentration } \\
(\mu \mathrm{M})\end{array}$ & {$[46]$} \\
\hline Lafutidine & $\begin{array}{l}\mathrm{H}_{2} \text {-receptor } \\
\text { antagonist }\end{array}$ & $\begin{array}{l}5 \text { humans } \\
\text { (healthy) }\end{array}$ & $10 \mathrm{mg}$ po tablet & $\begin{array}{c}\text { Equilibration delay } \\
\text { between the plasma } \\
\text { concentration and effect } \\
\text { site }\end{array}$ & $\begin{array}{l}\Delta \mathrm{pH} \text { after } \\
\text { postprandial } \\
\text { dose }\end{array}$ & $\begin{array}{l}\text { Lafutidine plasma } \\
\text { concentration }(\mathrm{ng} / \mathrm{mL})\end{array}$ & {$[47]$} \\
\hline Levosimendan & Calcium sensitizer & $\begin{array}{l}29 \text { humans } \\
\text { (congestive } \\
\text { heart failure) }\end{array}$ & $\begin{array}{c}0.2 \mu \mathrm{g} / \mathrm{kg} / \mathrm{min} 6 \mathrm{hr} \\
\text { continuous infusion or } \\
2 \mathrm{mg} \text { single po dose }\end{array}$ & $\begin{array}{c}\text { Delay of drug } \\
\text { distribution to its } \\
\text { cardiac site of action }\end{array}$ & $\begin{array}{c}\text { QS2i mean } \\
\text { change }(\mathrm{ms}) \\
\text { sBP mean } \\
\text { change } \\
\text { (mmHg) } \\
\text { dBP mean } \\
\text { change } \\
\text { (mmHg) } \\
\text { HR mean } \\
\text { changes } \\
\text { (bpm) }\end{array}$ & Levosimendan (ng/mL) & {$[48]$} \\
\hline Levosimendan & Calcium sensitizer & $\begin{array}{l}10 \text { humans } \\
\text { (healthy) }\end{array}$ & $\begin{array}{l}2 \mathrm{mg} \text { iv, tablet, } \\
\text { capsule, SR tablet } \\
\text { (single doses) }\end{array}$ & $\begin{array}{l}\text { Takes time for the drug } \\
\text { to distribute from } \\
\text { plasma to its cardiac } \\
\text { site of action }\end{array}$ & $\Delta \mathrm{QS} 2 \mathrm{i}(\mathrm{ms})$ & $\begin{array}{c}\text { Plasma concentrations of } \\
\text { levosimendan }\end{array}$ & [49] \\
\hline
\end{tabular}




\begin{tabular}{|c|c|c|c|c|c|c|c|}
\hline $\begin{array}{l}\text { Lignocaine } \\
\text { (Lidocaine) }\end{array}$ & Anesthetic & 5 sheep & $\begin{array}{l}50 \mathrm{mg}, 75 \mathrm{mg} \text { and } \\
100 \mathrm{mg} \text { iv bolus }\end{array}$ & $\begin{array}{l}\text { Lack of pseudo } \\
\text { equilibrium between } \\
\text { the drug concentrations } \\
\text { in the blood and at the } \\
\text { receptor sites } \\
\text { responsible for drug } \\
\text { action in the } \\
\text { myocardium }\end{array}$ & $\begin{array}{l}\text { Percentage } \\
\text { decreases of } \\
\text { myocardial } \\
\text { contractility }\end{array}$ & $\begin{array}{c}\text { Atrial lignocaine } \\
\text { concentrations }(\mu \mathrm{g} / \mathrm{mL}) \text { in } \\
\text { arterial blood and } \\
\text { coronary sinus blood }\end{array}$ & [50] \\
\hline Lisdexamfetamine & Stimulant & 22 rats & $\begin{array}{l}1.5 \mathrm{mg} / \mathrm{kg} \text { ip D- } \\
\text { amphetamine base } \\
5 \mathrm{mg} / \mathrm{kg} \text { ip D- } \\
\text { amphetamine base }\end{array}$ & None described & $\begin{array}{c}\text { Striatal } \\
\text { dopamine } \\
\text { concentration } \\
\text { (\% of } \\
\text { baseline) and } \\
\text { locomotor } \\
\text { activity }\end{array}$ & $\begin{array}{c}\text { Plasma amphetamine } \\
\text { (ng/mL) } \\
\text { Dopamine concentration } \\
\text { in the striatum ( } \% \text { of } \\
\text { baseline) }\end{array}$ & {$[28]^{*}$} \\
\hline$(+/-)$ Lorazepam & Benzodiazepine & $\begin{array}{l}6 \text { humans } \\
\text { (healthy) }\end{array}$ & $\begin{array}{l}0.057 \mathrm{mg} / \mathrm{kg} \text { solution } \\
\text { single oral dose }\end{array}$ & $\begin{array}{l}\text { The site of action of } \\
\text { lorazepam is kinetically } \\
\text { distinguishable from } \\
\text { the plasma } \\
\text { compartment and there } \\
\text { is a distinct time lag } \\
\text { between changes in } \\
\text { plasma concentration } \\
\text { and changes in CNS } \\
\text { effects }\end{array}$ & $\begin{array}{c}\text { Subcritical } \\
\text { tracking, sway } \\
\text { open and digit } \\
\text { symbol } \\
\text { substitution }\end{array}$ & $\begin{array}{c}\text { Plasma lorazepam } \\
\text { concentration }(\mathrm{ng} / \mathrm{mL})\end{array}$ & {$[51]$} \\
\hline (+/-) Lorazepam & Benzodiazepine & $\begin{array}{l}9 \text { humans } \\
\text { (healthy) }\end{array}$ & $\begin{array}{c}2 \mathrm{mg} \text { bolus iv loading } \\
\text { dose followed by a } 2 \\
\mu \mathrm{g} / \mathrm{kg} / \mathrm{hr} \text { infusion for } 4 \\
\mathrm{hrs}\end{array}$ & $\begin{array}{l}\text { Delay in equilibration } \\
\text { of lorazepam between } \\
\text { plasma and the site of } \\
\text { pharmacodynamics } \\
\text { action in the brain }\end{array}$ & $\begin{array}{l}\text { Percent beta } \\
\text { EEG } \\
\text { amplitude } \\
\text { (change over } \\
\text { baseline) } \\
\end{array}$ & $\begin{array}{c}\text { Plasma lorazepam } \\
\text { concentration }(\mathrm{ng} / \mathrm{mL})\end{array}$ & {$[52]$} \\
\hline Losartan & $\begin{array}{l}\text { Angiotensin II } \\
\text { receptor blocker }\end{array}$ & $\begin{array}{l}12 \text { humans } \\
\text { (healthy) }\end{array}$ & $50 \mathrm{mg}$ po & $\begin{array}{l}\text { Distributional delay } \\
\text { between the } \\
\text { concentrations in } \\
\text { plasma and effect site }\end{array}$ & $\begin{array}{l}\text { Pharmacodyn } \\
\text { amics (areas } \\
\text { under the } \\
\text { effect time } \\
\text { profile: DR- } \\
\text { 1) } \\
\end{array}$ & $\begin{array}{l}\text { Pharmacokinetics } \\
\text { (concentration } \\
\text { equivalents: } \mathrm{nKi} \text { ) }\end{array}$ & {$[22]$} \\
\hline (+/-) Meperidine & Opioid analgesic & Sheep & $\begin{array}{c}100 \mathrm{mg} \text { iv dose over } 1 \\
\text { second }\end{array}$ & None described & $\begin{array}{l}\text { Contractility } \\
\text { (\% reduction) }\end{array}$ & $\begin{array}{c}\text { Concentrations of } \\
\text { meperidine in } \\
\text { myocardium and coronary } \\
\text { sinus blood }(\mathrm{mg} / \mathrm{L})\end{array}$ & {$[53]^{*}$} \\
\hline
\end{tabular}


J Pharm Pharm Sci (www.cspsCanada.org) 17(1) 34 - 91, 2014

\begin{tabular}{|c|c|c|c|c|c|c|c|}
\hline Metformin & $\begin{array}{l}\text { Biguanide anti- } \\
\text { hyperglycemic }\end{array}$ & $\begin{array}{l}22 \text { humans } \\
\text { (healthy) }\end{array}$ & $500 \mathrm{mg}$ po & $\begin{array}{l}\text { Time delay between the } \\
\text { change in plasma } \\
\text { concentration and the } \\
\text { drug effects }\end{array}$ & $\begin{array}{l}\text { Change } \% \text { for } \\
\text { baseline in } \\
\text { plasma } \\
\text { glucose } \\
\text { concentration } \\
\end{array}$ & $\begin{array}{l}\text { Plasma concentration of } \\
\text { metformin }(\mu \mathrm{g} / \mathrm{mL})\end{array}$ & [54] \\
\hline Metocurine & $\begin{array}{l}\text { Neuromuscular } \\
\text { blocking agent }\end{array}$ & $\begin{array}{l}15 \text { dogs } \\
5 \text { pigs }\end{array}$ & $\begin{array}{l}\text { Brief, constant rate } \\
\text { infusion }\end{array}$ & $\begin{array}{l}\text { Equilibration delay } \\
\text { between drug } \\
\text { concentration in the } \\
\text { plasma and drug } \\
\text { concentration at the site } \\
\text { of effect }\end{array}$ & $\begin{array}{c}\% \mathrm{NM} \\
\text { blockade }\end{array}$ & $\begin{array}{l}\text { Plasma metocurine } \\
\qquad(\mu \mathrm{g} / \mathrm{mL})\end{array}$ & {$[55]$} \\
\hline Midazolam & Benzodiazepine & $\begin{array}{l}8 \text { humans } \\
\text { (healthy) }\end{array}$ & $\begin{array}{l}0.1 \mathrm{mg} / \mathrm{kg} \text { constant rate } \\
\text { iv infusion for } 1 \mathrm{~min}\end{array}$ & $\begin{array}{c}\text { Equilibration effect-site } \\
\text { delay }\end{array}$ & $\begin{array}{c}\text { Change in } \\
\% \text { SB }\end{array}$ & $\begin{array}{c}\text { Plasma midazolam } \\
\text { concentration }\end{array}$ & {$[52]$} \\
\hline Midazolam & Benzodiazepine & $\begin{array}{l}12 \text { humans } \\
\text { (healthy) }\end{array}$ & $\begin{array}{c}0.03 \mathrm{mg} / \mathrm{kg} \text { and } 0.07 \\
\mathrm{mg} / \mathrm{kg} \text { iv infusion (four } \\
\text { separate occasions) }\end{array}$ & $\begin{array}{l}\text { Lag time to onset of } \\
\text { peak effect }\end{array}$ & $\begin{array}{l}\text { Digital } \\
\text { Symbol } \\
\text { Substitution } \\
\text { Test Score } \\
\text { (number } \\
\text { correct) } \\
\end{array}$ & $\begin{array}{l}\text { Plasma concentration of } \\
\text { Midazolam }(\mathrm{ng} / \mathrm{ml})\end{array}$ & [301] \\
\hline Midazolam & Benzodiazepine & $\begin{array}{l}3 \text { humans } \\
\text { (healthy) }\end{array}$ & $\begin{array}{l}7.5,15 \text {, and } 25 \mathrm{mg} \text { iv } \\
\text { infusion at } 5 \mathrm{mg} / \mathrm{min}\end{array}$ & $\begin{array}{c}\text { Disequilibrium } \\
\text { between plasma and } \\
\text { effect compartment }\end{array}$ & $\begin{array}{l}\text { EEG drug } \\
\text { effect }(u V)\end{array}$ & $\begin{array}{l}\text { Plasma concentration of } \\
\text { Midazolam }(\mathrm{ng} / \mathrm{ml})\end{array}$ & {$[302]$} \\
\hline Molsidomine & Vasodialator & $\begin{array}{l}11 \text { humans } \\
\text { (CAD) }\end{array}$ & 4 mg po (single dose) & Active metabolite & $\begin{array}{c}\text { Decrease in } \\
\text { end-diastolic } \\
\text { diameter }\end{array}$ & $\begin{array}{l}\text { Plasma concentration of } \\
\text { molsidomine }(\mu \mathrm{g} / \mathrm{mL})\end{array}$ & {$[56]$} \\
\hline $\begin{array}{c}(+/-) \\
\text { Morphine }\end{array}$ & Opioid analgesic & Rats & $\begin{array}{c}2.5 \mathrm{mg} / \mathrm{kg} \\
\text { Intraperitoneal } \\
\\
2.5 \mathrm{mg} / \mathrm{kg} \\
\text { Nose drops } \\
\end{array}$ & $\begin{array}{l}\text { Direct nose-to-CNS } \\
\text { drug transport } \\
\text { mechanisim }\end{array}$ & $\begin{array}{l}\text { Analgesic } \\
\text { effect } \\
(\% \mathrm{MPE})\end{array}$ & Morphine (ng/ml) & {$[57]^{*}$} \\
\hline $\begin{array}{c}(+/-) \\
\text { Morphine }\end{array}$ & Opioid analgesic & Rats & $\begin{array}{l}14.0 \mathrm{mmol} / \mathrm{kg} \\
\text { morphine }\end{array}$ & $\begin{array}{c}\text { Delay of polar } \\
\text { morphine crossing the } \\
\text { BBB }\end{array}$ & $\begin{array}{l}\% \text { Anti- } \\
\text { nociceptive } \\
\text { response } \\
\text { (using tail } \\
\text { flick method) }\end{array}$ & $\begin{array}{l}\text { Plasma morphine } \\
(\mu \mathrm{mol} / \mathrm{L}) \text { and Brain } \\
\text { morphine }(\mathrm{nmol} / \mathrm{g}) \text {, }\end{array}$ & {$[58]^{*}$} \\
\hline $\begin{array}{c}(+/-) \\
\text { Morphine }\end{array}$ & Opioid analgesic & Rats & $\begin{array}{c}15 \mathrm{mg} / \mathrm{kg} \text { morphine } \\
\text { through intragastric } \\
\text { administration (single } \\
\text { dose) }\end{array}$ & $\begin{array}{c}\text { Disequilibrium between } \\
\text { biophase and plasma } \\
\text { compartments }\end{array}$ & $\begin{array}{c}\text { \%MPE on } \\
\text { MPR } \\
\text { (mechanical } \\
\text { pain response) }\end{array}$ & $\begin{array}{c}\text { Concentration of blood } \\
\text { morphine }(\mu \mathrm{g} / \mathrm{L}), \\
\text { concentration of CSF } \\
\text { morphine }(\mu \mathrm{g} / \mathrm{L}), \text { both } \\
\text { conjugated and } \\
\text { unconjugated }\end{array}$ & {$[59]^{*}$} \\
\hline
\end{tabular}


J Pharm Pharm Sci (www.cspsCanada.org) 17(1) 34 - 91, 2014

\begin{tabular}{|c|c|c|c|c|c|c|c|}
\hline Morphine & Opioid analgesic & Rats & $\begin{array}{c}10 \text { minute i.v. infusion } \\
\text { at } 4 \mathrm{mg} / \mathrm{kg}\end{array}$ & Effect compartment & $\begin{array}{c}\text { EEG } \\
\text { amplitude } 0.5- \\
4.5 \mathrm{~Hz}(\mu \mathrm{V})\end{array}$ & $\begin{array}{c}\text { Morphine blood } \\
\text { concentration }(\mathrm{ng} / \mathrm{ml})\end{array}$ & {$[328]^{*}$} \\
\hline Naproxen & $\begin{array}{l}\text { Non-steroidal anti- } \\
\text { inflammatory agent }\end{array}$ & $\begin{array}{l}\text { Rats (induced } \\
\text { hepatitis) }\end{array}$ & $\begin{array}{c}6 \mathrm{mg} / \mathrm{kg} \text { po (single } \\
\text { dose) }\end{array}$ & $\begin{array}{c}\text { Slow transport of } \\
\text { naproxen from } \\
\text { circulation to its site of } \\
\text { action }\end{array}$ & $\begin{array}{l}\text { Protection } \\
\quad(\%)\end{array}$ & $\begin{array}{l}\text { Plasma concentration of } \\
\text { naproxen }(\mu \mathrm{g} / \mathrm{mL})\end{array}$ & {$[60]$} \\
\hline Nitroglycerin & Vasodilator & $\begin{array}{l}6 \text { humans } \\
\text { (healthy) }\end{array}$ & $\begin{array}{c}10,20,40 \mu \mathrm{g} / \mathrm{min} \text { iv } \\
\text { infusions }\end{array}$ & $\begin{array}{l}\text { End product inhibition } \\
\text { or saturable binding of } \\
\text { nitroglycerin to blood } \\
\text { vessels }\end{array}$ & $\begin{array}{l}\text { Nitroglycerin } \\
\text { Css }(\mathrm{ng} / \mathrm{mL})\end{array}$ & Infusion rate $(\mu \mathrm{g} / \mathrm{min})$ & {$[61]$} \\
\hline Nitroglycerin & Vasodilator & 4 dogs & $\begin{array}{c}10,20,50,70 \mu \mathrm{g} / \mathrm{min} \\
\text { iv infusion }\end{array}$ & Active metabolites & $\begin{array}{l}\text { Systolic blood } \\
\text { pressure } \\
\text { decreases } \\
(\mathrm{mmHg})\end{array}$ & $\begin{array}{c}\text { Nitroglycerin } \\
\text { concentration }(\mathrm{ng} / \mathrm{mL})\end{array}$ & {$[62]$} \\
\hline NPH insulin & $\begin{array}{c}\text { Intermediate acting } \\
\text { insulin }\end{array}$ & $\begin{array}{l}6 \text { humans } \\
\text { (healthy) }\end{array}$ & $\begin{array}{c}25 \mathrm{U} \text { single } \\
\text { subcutaneous dose }\end{array}$ & $\begin{array}{c}\text { Delay between serum } \\
\text { insulin concentrations } \\
\text { and effect }\end{array}$ & $\begin{array}{c}\text { Glucose } \\
\text { infusion rate } \\
(\mathrm{mmol} / \mathrm{min}) \\
\end{array}$ & $\begin{array}{c}\text { Measured serum } \\
\text { concentration }(\mathrm{pmol} / \mathrm{L})\end{array}$ & {$[63]$} \\
\hline Pancuronium & $\begin{array}{l}\text { Neuromuscular } \\
\text { blocking agent }\end{array}$ & $\begin{array}{l}11 \text { humans } \\
\text { (undergoing } \\
\text { elective } \\
\text { surgery) } \\
\end{array}$ & $\begin{array}{l}2 \text { or } 4 \mu \mathrm{g} / \mathrm{kg} / \mathrm{min} \text { by } \\
\text { i.v. infusion }\end{array}$ & Effect compartment & $\begin{array}{c}\text { Degree of } \\
\text { neuromuscula } \\
\text { r paralysis } \\
(\%) \\
\end{array}$ & $\begin{array}{l}\text { Plasma concentration } \\
\qquad(\mu \mathrm{g} / \mathrm{mL})\end{array}$ & {$[307]^{*}$} \\
\hline Paroxetine & $\begin{array}{c}\text { Selective serotonin } \\
\text { reuptake inhibitor }\end{array}$ & Mice & $\begin{array}{c}0.27 \mathrm{mg} / \mathrm{kg} \text { single sub } \\
\text { cut injection }\end{array}$ & $\begin{array}{l}\text { Slow permeation over } \\
\text { the blood-brain barrier }\end{array}$ & 5-HTP Score & $\begin{array}{c}\text { Paroxetine serum } \\
\text { concentration }(\mathrm{ng} / \mathrm{mL})\end{array}$ & {$[33]$} \\
\hline (+/-) Penbutolol & Beta-blocker & $\begin{array}{l}7 \text { humans } \\
\text { (healthy) }\end{array}$ & $\begin{array}{c}40 \mathrm{mg} \text { po film-coated } \\
\text { tablets }\end{array}$ & $\begin{array}{l}\text { Active metabolite } \\
\text { formation }\end{array}$ & $\begin{array}{c}\text { Standardized } \\
\text { antagonist } \\
\text { concentration } \\
\text { in plasma } \\
\left(\mathrm{I}_{\mathrm{AN}} / \mathrm{K}_{\mathrm{IAN}}\right) \\
\end{array}$ & $\begin{array}{l}\text { Standardized penbutolol } \\
\text { concentration in plasma } \\
\qquad\left(\mathrm{C}_{\mathrm{pen}} / \mathrm{K}_{\mathrm{ip}}\right)\end{array}$ & {$[64]$} \\
\hline Perindoprilat & $\begin{array}{l}\text { Perindopril (ACEI) } \\
\text { active metabolite }\end{array}$ & $\begin{array}{l}10 \text { humans } \\
\text { (CHF) }\end{array}$ & 4 mg po (single dose) & Effect compartment & $\begin{array}{c}\text { Plasma } \\
\text { converting } \\
\text { enzyme } \\
\text { activity } \\
\text { (PCEA) and } \\
\text { brachial } \\
\text { vascular } \\
\text { resistance } \\
\text { (BVR) }\end{array}$ & $\begin{array}{l}\text { Plasma concentrations of } \\
\text { perindoprilat }(\mathrm{ng} / \mathrm{ml})\end{array}$ & {$[310]$} \\
\hline Pimobendan & Vasodilator & $\begin{array}{l}8 \text { humans } \\
\text { (healthy) }\end{array}$ & $\begin{array}{l}7.5 \mathrm{mg} \text { po } \\
5 \mathrm{mg} \text { iv }\end{array}$ & $\begin{array}{l}\text { Effect-compartment } \\
\text { model }\end{array}$ & $\begin{array}{l}\% \text { of maximal } \\
\text { decrease in } \\
\text { LVESD }\end{array}$ & $\begin{array}{l}\text { Pimobendan in plasma } \\
\qquad(\mathrm{ng} / \mathrm{mL})\end{array}$ & {$[65]$} \\
\hline
\end{tabular}


J Pharm Pharm Sci (www.cspsCanada.org) 17(1) 34 - 91, 2014

\begin{tabular}{|c|c|c|c|c|c|c|c|}
\hline Pinacidil & Vasodilator & $\begin{array}{l}12 \text { humans } \\
\text { (healthy) }\end{array}$ & $\begin{array}{c}25 \mathrm{mg} \text { tablet or capsule } \\
\text { po once daily for } 1 \\
\text { week }\end{array}$ & Time lag to equilibrium & $\begin{array}{c}\text { Mean HR } \\
\text { (beats/min) } \\
\text { Mean } \Delta \mathrm{HR} \\
\text { (beats/min) } \\
\text { Mean DBP } \\
\text { (mm Hg) } \\
\text { Mean } \Delta \mathrm{DBO} \\
(\mathrm{mm} \mathrm{Hg})\end{array}$ & $\begin{array}{l}\text { Mean extrapolated CP } \\
(\mathrm{ng} / \mathrm{mL})\end{array}$ & [66] \\
\hline Pregabalin & $\begin{array}{c}\text { Analgesic/ } \\
\text { anticonvulsant }\end{array}$ & Rats & $6 \mathrm{mg} / \mathrm{kg}$ po & Not active metabolite & $\begin{array}{c}\% \text { protection } \\
\text { MES }\end{array}$ & $\begin{array}{c}\text { Pregabalin ECF } \\
\text { concentration }(\mathrm{ng} / \mathrm{mL})\end{array}$ & {$[67]$} \\
\hline Propofol & General anesthetic & Sheep & $\begin{array}{c}100 \mathrm{mg} \text { iv infusion } \\
\text { over } 2 \text { min }\end{array}$ & $\begin{array}{l}\text { Disequilibrium due to } \\
\text { organ drug uptake } \\
\text { following rapid drug } \\
\text { administration. }\end{array}$ & $\begin{array}{c}\text { Depth of } \\
\text { anesthesia (\% } \\
\text { baseline) } \\
\text { CBF } \\
(\mathrm{mL} / \mathrm{min}) \\
\end{array}$ & $\begin{array}{c}\text { Arterial concentrations } \\
(\mu \mathrm{g} / \mathrm{mL}) \\
\text { Sagittal sinus } \\
\text { concentrations }(\mu \mathrm{g} / \mathrm{mL}) \\
\text { Arterial concentrations } \\
(\mu \mathrm{g} / \mathrm{mL}) \\
\end{array}$ & {$[68]^{*}$} \\
\hline (+/-) Propranolol & Beta-blocker & 6 humans & $\begin{array}{l}3 \times 20 \mathrm{mg} \text { PL po tablet } \\
\text { or } 60 \mathrm{mg} \text { LA po tablet }\end{array}$ & $\begin{array}{l}\text { Two distinct beta- } \\
\text { adrenoceptor binding } \\
\text { sites on the surface } \\
\text { membrane which differ } \\
\text { in lipophilic } \\
\text { characteristics }\end{array}$ & $\begin{array}{l}\text { Beta-blocking } \\
\text { activity }(\% \mathrm{R})\end{array}$ & $\begin{array}{c}\text { Plasma propranolol } \\
\text { concentration }(\mu \mathrm{g} / \mathrm{mL})\end{array}$ & {$[304]^{*}$} \\
\hline$(+/-)$ Quinine & Antimalarial & $\begin{array}{l}6 \text { humans } \\
\text { (healthy) }\end{array}$ & $\begin{array}{c}15 \mathrm{mg} / \mathrm{kg} \text { po dose and } \\
15 \mathrm{mg} / \mathrm{kg} \text { iv infusion } \\
\text { administered over } 6 \\
\text { hours }\end{array}$ & None described & $\begin{array}{l}\text { Hearing } \\
\text { threshold shift } \\
\text { (dB) }\end{array}$ & $\begin{array}{c}\text { Quinine plasma } \\
\text { concentration }(\mu \mathrm{mol} / \mathrm{L})\end{array}$ & {$[309]$} \\
\hline $\begin{array}{c}\text { (R)-3-[1-(2,6- } \\
\text { Dichloro-3-fluoro- } \\
\text { phenyl)-ethoxy]-5- } \\
\text { (1-piperidin-4-yl- } \\
\text { 1H-pyrazol-4-yl)- } \\
\text { pyridin-2-ylamine } \\
\text { (PF02341066) }\end{array}$ & $\begin{array}{l}\text { ATP-competitive } \\
\text { small molecule } \\
\text { inhibitor of cMet } \\
\text { receptor tyrosine } \\
\text { kinase }\end{array}$ & $\begin{array}{l}\text { Mice (GTL16 } \\
\text { gastric } \\
\text { carcinoma or } \\
\text { U87MG } \\
\text { glioblastoma } \\
\text { xenografts) }\end{array}$ & $\begin{array}{c}\text { Oral administration of } \\
8.5,17, \text { and } 34 \mathrm{mg} / \mathrm{kg} \text {; } \\
3.13,6.25,12.5,25 \text {, } \\
\text { and } 50 \mathrm{mg} / \mathrm{kg} \text {; and } \\
3.13,6.25,12.5,25 \\
\text { and } 50 \mathrm{mg} / \mathrm{kg}\end{array}$ & $\begin{array}{l}\text { Slow distribution to } \\
\text { tumors }\end{array}$ & $\begin{array}{l}\text { cMet } \\
\text { phosphorylati } \\
\text { on response }\end{array}$ & $\begin{array}{l}\text { Plasma concentration of } \\
\text { PF02341066 (ng/ml) }\end{array}$ & {$[327]$} \\
\hline Ranitidine & $\begin{array}{l}\mathrm{H}_{2} \text {-receptor } \\
\text { antagonist }\end{array}$ & $\begin{array}{l}41 \text { humans } \\
\text { (renal } \\
\text { impairment) }\end{array}$ & $\begin{array}{l}\text { Single } 50 \mathrm{mg} \text { and } 25 \\
\mathrm{mg} \text { iv doses }\end{array}$ & Effect compartment & Gastric $\mathrm{pH}$ & $\begin{array}{c}\text { Serum ranitidine } \\
\text { concentration }(\mathrm{ng} / \mathrm{ml})\end{array}$ & {$[310]$} \\
\hline Regular insulin & Peptide hormone & $\begin{array}{l}10 \text { humans } \\
\text { (healthy) }\end{array}$ & $\begin{array}{c}10 \mathrm{U} \text { single } \\
\text { subcutaneous dose }\end{array}$ & $\begin{array}{c}\text { Delay between serum } \\
\text { insulin concentrations } \\
\text { and effect }\end{array}$ & $\begin{array}{c}\text { Glucose } \\
\text { infusion rate } \\
(\mathrm{mmol} / \mathrm{min}) \\
\end{array}$ & $\begin{array}{c}\text { Measured serum } \\
\text { concentration }(\mathrm{pmol} / \mathrm{L})\end{array}$ & {$[63]$} \\
\hline Remifentanil & Opioid analgesic & $\begin{array}{l}10 \text { humans } \\
\text { (healthy) }\end{array}$ & $\begin{array}{c}3 \mu \mathrm{g} / \mathrm{kg} / \mathrm{min} \text { for } 10 \\
\text { minutes }\end{array}$ & $\begin{array}{l}\text { Equilibrium delay } \\
\text { between arterial opioid } \\
\text { concentration and } \\
\text { concentration at the site } \\
\text { of drug effect (brain) }\end{array}$ & $\begin{array}{l}\text { Spectral Edge } \\
(\mathrm{Hz}) \\
\text { (opioid effect) }\end{array}$ & $\begin{array}{c}\text { Arterial remifentanil } \\
\text { concentration }(\mathrm{ng} / \mathrm{mL})\end{array}$ & {$[69]^{*}$} \\
\hline
\end{tabular}


J Pharm Pharm Sci (www.cspsCanada.org) 17(1) 34 - 91, 2014

\begin{tabular}{|c|c|c|c|c|c|c|c|}
\hline Risperidone & $\begin{array}{l}\text { Antipsychotic } \\
\text { agent }\end{array}$ & $\begin{array}{l}9 \text { humans } \\
\text { (healthy) }\end{array}$ & $1 \mathrm{mg}$ po (single dose) & $\begin{array}{c}\text { Drug moves from the } \\
\text { plasma to the effect } \\
\text { compartment after time } \\
\text { delay }\end{array}$ & EEG effect & $\begin{array}{l}\text { Plasma concentration of } \\
\text { risperidone }(\mathrm{ng} / \mathrm{mL})\end{array}$ & [70] \\
\hline Roxithromycin & $\begin{array}{l}\text { Macrolide } \\
\text { antibiotic }\end{array}$ & Rats & $\begin{array}{c}20,40 \mathrm{mg} / \mathrm{kg} / \mathrm{h} \text { iv over } \\
90 \mathrm{~min}\end{array}$ & $\begin{array}{l}\text { Delayed distribution in } \\
\text { the effect site, } \\
\text { potassium channels on } \\
\text { ventricular myocytes }\end{array}$ & $\begin{array}{l}\text { Change in QT } \\
\text { interval } \\
(\mathrm{msec})\end{array}$ & $\begin{array}{l}\text { Plasma concentration of } \\
\text { roxithromycin }(\mu \mathrm{g} / \mathrm{mL})\end{array}$ & [16] \\
\hline Sertraline & $\begin{array}{l}\text { Selective serotonin } \\
\text { reuptake inhibitor }\end{array}$ & Mice & $\begin{array}{l}2.2 \mathrm{mg} / \mathrm{kg} \text { single sub } \\
\text { cut injection }\end{array}$ & $\begin{array}{l}\text { Slow permeation over } \\
\text { the blood-brain barrier }\end{array}$ & 5-HTP Score & $\begin{array}{c}\text { Sertraline serum } \\
\text { concentration }(\mathrm{ng} / \mathrm{mL})\end{array}$ & [33] \\
\hline Sevoflurane & General anesthetic & $\begin{array}{l}21 \text { Humans } \\
\text { (healthy) }\end{array}$ & $\begin{array}{l}\text { Inhalation initially at } \\
1 \% \text { then increased by } \\
1 \% \text { to a max of } 8 \% \text {. } \\
\text { Then decrease to } 1 \%\end{array}$ & $\begin{array}{c}\text { Delay of drug } \\
\text { concentration at the } \\
\text { effect site }\end{array}$ & $\begin{array}{l}\text { QTc interval } \\
(\mathrm{m} \mathrm{sec})\end{array}$ & $\begin{array}{l}\text { End-tidal sevoflurane } \\
\text { concentration }(\%)\end{array}$ & {$[71]$} \\
\hline Sinemet & $\begin{array}{l}\text { Anti-parkinson's } \\
\text { agent }\end{array}$ & $\begin{array}{l}11 \text { humans } \\
\text { (Parkinson's) }\end{array}$ & $\begin{array}{l}\text { Carbidopa } 25 \mathrm{mg} / \mathrm{L}- \\
\text { DOPA } 100 \mathrm{mg} \text { po }\end{array}$ & $\begin{array}{l}\text { Takes time for L- } \\
\text { DOPA to distribute to } \\
\text { the central nervous } \\
\text { system }\end{array}$ & $\begin{array}{l}\text { Taps per } 60 \\
\text { seconds }\end{array}$ & Levodopa $(\mu \mathrm{g} / \mathrm{mL})$ & {$[72]$} \\
\hline Tacrolimus & $\begin{array}{l}\text { Calcineurin } \\
\text { Inhibitor }\end{array}$ & Rats & $\begin{array}{l}\text { Prograf single injection } \\
0.1 \text { and } 5 \mathrm{mg} / \mathrm{mL}\end{array}$ & $\begin{array}{l}\text { Delay in distribution of } \\
\text { the drug to effect site }\end{array}$ & $\begin{array}{c}\text { Calcineurin } \\
\text { inhibition }(\%)\end{array}$ & $\begin{array}{l}\text { Tacrolimus concentration } \\
\qquad(\mathrm{ng} / \mathrm{mL})\end{array}$ & {$[26]$} \\
\hline Tacrolimus & $\begin{array}{l}\text { Calcineurin } \\
\text { inhibitor }\end{array}$ & 5 guinea pigs & $\begin{array}{c}0.01 \text { or } 0.1 \mathrm{mg} / \mathrm{hr} / \mathrm{kg} \text { iv } \\
\text { infusion }\end{array}$ & $\begin{array}{l}\text { The delay in } \\
\text { distribution from blood } \\
\text { to the ventricle }\end{array}$ & $\begin{array}{l}\text { Change in } \\
\text { QTc (msec) }\end{array}$ & $\begin{array}{c}\text { Plasma tacrolimus } \\
\text { concentration }(\mathrm{ng} / \mathrm{mL}) \\
\text { Whole blood tacrolimus } \\
(\mathrm{ng} / \mathrm{mL})\end{array}$ & {$[73]$} \\
\hline Telmisartan & $\begin{array}{l}\text { Angiotensin II } \\
\text { receptor blocker }\end{array}$ & $\begin{array}{l}48 \text { humans } \\
\text { (healthy) }\end{array}$ & $20,40,80 \mathrm{mg}$ ро & $\begin{array}{c}\text { Delay and longer } \\
\text { persistence of effect } \\
\text { than expected, slow } \\
\text { dissociation from the } \\
\text { receptor }\end{array}$ & Inhibition (\%) & $\begin{array}{l}\text { Plasma concentration of } \\
\text { telmisartan }(\mathrm{mg} / \mathrm{L})\end{array}$ & {$[74]$} \\
\hline Terfentanil & $\begin{array}{l}\text { Opioid analgesic } \\
\text { (investigational) }\end{array}$ & $\begin{array}{l}14 \text { humans } \\
\text { (healthy) }\end{array}$ & $\begin{array}{c}4 \mu \mathrm{g} / \mathrm{kg} / \mathrm{min} \text { for a } \\
\text { maximum of } 30 \\
\text { minutes or until } \\
\text { maximum EEG } \\
\text { changes occurred } \\
\text { (adjusted by } \\
\text { investigators) }\end{array}$ & Effect compartment & $\begin{array}{l}\text { Spectral edge } \\
\quad(95 \%) \mathrm{Hz}\end{array}$ & $\begin{array}{l}\text { Plasma terfentanil } \\
\text { concentration }(\mathrm{ng} / \mathrm{ml})\end{array}$ & {$[318]$} \\
\hline $\begin{array}{l}\text { Tesofensine active } \\
\text { metabolite (M1) }\end{array}$ & $\begin{array}{c}\text { serotonin- } \\
\text { noradrenaline- } \\
\text { dopamine reuptake } \\
\text { inhibitor }\end{array}$ & 228 mice & $\begin{array}{c}0.3 \text { to } 20 \mathrm{mg} / \mathrm{kg} \text { iv and } \\
\text { po }\end{array}$ & $\begin{array}{l}\text { Distribution of the } \\
\text { molecules between the } \\
\text { plasma and the central } \\
\text { nervous system }\end{array}$ & Inhibition $(\%)$ & $\begin{array}{c}\text { Tesofinsine plasma } \\
\text { concentration }(\mathrm{ng} / \mathrm{mL})\end{array}$ & {$[75]$} \\
\hline
\end{tabular}


J Pharm Pharm Sci (www.cspsCanada.org) 17(1) 34 - 91, 2014

\begin{tabular}{|c|c|c|c|c|c|c|c|}
\hline (+/-) Thiopental & $\begin{array}{c}\text { General anesthetic } \\
\text { Barbiturate }\end{array}$ & 4 sheep & $750 \mathrm{mg}$ iv over $2 \mathrm{~min}$ & $\begin{array}{l}\text { Presence of effect } \\
\text { compartment }\end{array}$ & $\begin{array}{l}\text { Maximum } \\
\text { rate of change } \\
\text { of left } \\
\text { ventricular } \\
\text { pressure }(\% \\
\text { reduction } \\
\text { from baseline) }\end{array}$ & $\begin{array}{l}\text { Thiopental concentrations } \\
\text { of arterial }(\mu \mathrm{g} / \mathrm{mL}) \text { and } \\
\text { coronary sinus }(\mu \mathrm{g} / \mathrm{mL})\end{array}$ & {$[76]$} \\
\hline Tinzaparin & $\begin{array}{l}\text { Low molecular } \\
\text { weight heparin }\end{array}$ & 6 dogs & $4 \mathrm{mg} / \mathrm{kg} \mathrm{sC}$ & $\begin{array}{l}\text { Delay in systemic } \\
\text { availability }\end{array}$ & $\begin{array}{l}\text { Anti-factor } \\
\text { Xa activity } \\
\text { (IU/mL) } \\
\text { (biological } \\
\text { effect) }\end{array}$ & $\begin{array}{l}\text { Plasma concentration of } \\
\text { heparin material }\end{array}$ & {$[77]$} \\
\hline Triazolam & Benzodiazepine & $\begin{array}{l}10 \text { humans } \\
\text { (healthy) }\end{array}$ & $\begin{array}{l}1 \text { mg solution po } \\
\text { (single dose) }\end{array}$ & $\begin{array}{l}\text { The site of action of } \\
\text { triazolam is kinetically } \\
\text { distinguishable from } \\
\text { the plasma } \\
\text { compartment and } \\
\text { contains a distinct time } \\
\text { lag between changes in } \\
\text { the plasma } \\
\text { concentration and } \\
\text { changes in CNS effect }\end{array}$ & $\begin{array}{c}\text { Subcritical } \\
\text { tracking, body } \\
\text { sway and digit } \\
\text { symbol } \\
\text { substitution }\end{array}$ & Plasma triazolam $(\mathrm{ng} / \mathrm{mL})$ & {$[78]$} \\
\hline Trimoprostil & $\begin{array}{l}\text { Prostaglandin } E_{2} \\
\text { analog }\end{array}$ & dogs & $\begin{array}{l}250 \mu \mathrm{g} \text { po capsule } \\
500 \mu \mathrm{g} \text { po capsule } \\
250 \mu \mathrm{g} \text { po solution }\end{array}$ & $\begin{array}{c}\text { Delay in equilibrium } \\
\text { between plasma } \\
\text { concentrations and } \\
\text { concentrations at the } \\
\text { site of action }\end{array}$ & $\begin{array}{l}\text { Mean \% } \\
\text { inhibition of } \\
\text { gastric acid } \\
\text { secretion }\end{array}$ & $\begin{array}{l}\text { Mean trimoprostil plasma } \\
\text { concentrations }(\mathrm{ng} / \mathrm{mL})\end{array}$ & {$[79]$} \\
\hline (+/-) Verapamil & $\begin{array}{l}\text { Calcium channel } \\
\text { blocker }\end{array}$ & $\begin{array}{l}22 \text { humans } \\
\text { (healthy) }\end{array}$ & $\begin{array}{c}\text { Single dose i.v. } \\
\text { infusion }(0.15-0.22 \\
\mathrm{mg} / \mathrm{kg})\end{array}$ & $\begin{array}{c}\text { Time lag between } \\
\text { plasma verapamil } \\
\text { concentrations and } \\
\text { maximal drug effect on } \\
\text { AV conduction }\end{array}$ & $\begin{array}{l}\text { Change in PR } \\
\text { interval (ms) }\end{array}$ & $\begin{array}{c}\text { Plasma verapamil } \\
\text { concentration }(\mathrm{ng} / \mathrm{ml})\end{array}$ & [311] \\
\hline Zabiciprilat & $\begin{array}{l}\text { Zabicipril (ACEI) } \\
\text { active metabolite }\end{array}$ & $\begin{array}{l}6 \text { humans } \\
\text { (healthy) }\end{array}$ & $\begin{array}{l}0.5 \text { and } 2.5 \mathrm{mg} \text { po } \\
\text { zabicipril }\end{array}$ & Effect compartment & $\begin{array}{c}\text { Plasma } \\
\text { converting } \\
\text { enzyme } \\
\text { activity } \\
\text { (PCEA) and } \\
\text { brachial/femo } \\
\text { ral artery flow } \\
\text { (BAF, FAF } \\
\text { ml/min) }\end{array}$ & $\begin{array}{l}\text { Zabiciprilat plasma } \\
\text { concentration }(\mathrm{ng} / \mathrm{ml})\end{array}$ & [312] \\
\hline
\end{tabular}

+/- Indicates Racemic Drug with Enantiomers

* Indicates Drug listed in both Table 2 and 3 


\begin{tabular}{|c|c|c|c|c|c|c|c|}
\hline Drug name & $\begin{array}{l}\text { Drug Class } \\
\text { (Indication) }\end{array}$ & $\begin{array}{c}\text { Population / } \\
\text { species studied } \\
\text { (Comorbidities) }\end{array}$ & $\begin{array}{c}\text { Route of } \\
\text { Administration }\end{array}$ & $\begin{array}{c}\text { Proposed } \\
\text { mechanism(s) }\end{array}$ & $\begin{array}{l}\text { Effect(s) } \\
\text { measured }\end{array}$ & $\begin{array}{c}\text { Site of drug } \\
\text { concentration measure }\end{array}$ & Reference \\
\hline Alprazolam & Benzodiazepine & $\begin{array}{l}21 \text { humans } \\
\text { (healthy) }\end{array}$ & $10 \mathrm{mg}$ SR po & Tolerance & $\begin{array}{c}\text { Mean } \\
\text { percentage of } \\
\text { decrement in } \\
\text { Digit-symbol } \\
\text { substitution } \\
\text { test scores } \\
\text { (sedation } \\
\text { scores) } \\
\end{array}$ & $\begin{array}{l}\text { Venous blood samples } \\
\text { from antecubital vein } \\
\text { Mean alprazolam } \\
\text { concentration }\end{array}$ & {$[80]$} \\
\hline Alprazolam & Benzodiazepine & $\begin{array}{l}24 \text { humans } \\
\text { (healthy) }\end{array}$ & $\begin{array}{l}2 \mathrm{mg} \text { po (two single } \\
\text { doses } 15 \text { days apart) }\end{array}$ & Tolerance & $\begin{array}{c}\text { Relative B-1 } \\
\text { activity (\%), } \\
\text { relative alpha } \\
\text { activity (\%), } \\
\text { total number } \\
\text { of responses, } \\
\text { correct } \\
\text { number of } \\
\text { responses, } \\
\text { activity (mm), } \\
\text { drowsiness } \\
(\mathrm{mm})\end{array}$ & $\begin{array}{l}\text { Alprazolam plasma } \\
\text { concentration (ng/ml) }\end{array}$ & {$[81]$} \\
\hline Amitriptyline & $\begin{array}{c}\text { Tricyclic anti- } \\
\text { depressant }\end{array}$ & $\begin{array}{l}24 \text { humans } \\
\text { (healthy) }\end{array}$ & $\begin{array}{c}75 \text { mg po controlled } \\
\text { drug delivery or IR } \\
\text { tablets }\end{array}$ & $\begin{array}{l}\text { Tolerance and } \\
\text { distributional } \\
\text { characteristics }\end{array}$ & $\begin{array}{l}\text { Change in dry } \\
\text { mouth from } \\
\text { baseline } \\
\text { (VAS), } \\
\text { change in } \\
\text { drowsiness } \\
\text { from baseline } \\
\text { (VAS) }\end{array}$ & $\begin{array}{l}\text { Amitriptyline plasma } \\
\text { concentration }(\mathrm{ng} / \mathrm{mL})\end{array}$ & {$[82]$} \\
\hline $\begin{array}{c}(+/-) \\
\text { Apomorphine }\end{array}$ & $\begin{array}{c}\text { Non-selective } \\
\text { Dopamine Agonist }\end{array}$ & $\begin{array}{c}10 \text { humans } \\
\text { (advanced } \\
\text { Parkinson's } \\
\text { disease with end } \\
\text { of dose } \\
\text { fluctuations) } \\
\end{array}$ & $0.5,1,2,4 \mathrm{mg}$ subcut & $\begin{array}{c}\text { Tolerance } \\
\text { Redistribution from } \\
\text { effect site }\end{array}$ & $\begin{array}{c}\text { CURS } \\
\text { (Columbia } \\
\text { University } \\
\text { Rating Scale) }\end{array}$ & Apomorphine (pMol/ml) & [83] \\
\hline $\begin{array}{c}(+/-) \\
\text { Atenolol }\end{array}$ & $\begin{array}{l}\text { Beta-1 Selective } \\
\text { Beta-Blocker }\end{array}$ & 10 rats & $\begin{array}{l}\text { Sustained release } \\
\text { pellets } 16 \mathrm{mg} / \mathrm{kg} \text { po } \\
\text { single dose }\end{array}$ & $\begin{array}{l}\text { Tolerance induced by } \\
\text { desensitization or } \\
\text { production of regulatory } \\
\text { substances }\end{array}$ & $\begin{array}{l}\text { Change in } \\
\text { Systolic blood } \\
\text { pressure } \\
(\mathrm{mmHg})\end{array}$ & $\begin{array}{l}\text { Atenolol concentration } \\
\qquad(\mu \mathrm{g} / \mathrm{mL})\end{array}$ & {$[14]^{*}$} \\
\hline
\end{tabular}


J Pharm Pharm Sci (www.cspsCanada.org) 17(1) 34 - 91, 2014

\begin{tabular}{|c|c|c|c|c|c|c|c|}
\hline Befloxatone & $\begin{array}{c}\text { Selective } \\
\text { monoamine oxidase } \\
\text { A inhibitor }\end{array}$ & $\begin{array}{l}12 \text { humans } \\
\text { (healthy) }\end{array}$ & $\begin{array}{c}5 \mathrm{mg} \text { capsules bid po } \\
\text { or } \\
10 \mathrm{mg} \text { capsules once } \\
\text { daily po }\end{array}$ & $\begin{array}{l}\text { Compartment effect or } \\
\text { an indirect response }\end{array}$ & $\begin{array}{l}\% \text { of DHPG } \\
\text { decrease from } \\
\text { baseline }\end{array}$ & $\begin{array}{l}\text { Befloxatone concentration } \\
\text { (ng/ml) }\end{array}$ & {$[84]$} \\
\hline Bumetanide & Loop Diuretic & $\begin{array}{l}3 \text { humans } \\
\text { (healthy) }\end{array}$ & $1 \mathrm{mg}$ SR capsules po & Tolerance & $\begin{array}{l}\text { Urine flow } \\
\text { rate }(\mathrm{ml} / \mathrm{hr})\end{array}$ & $\begin{array}{l}\text { Plasma concentration of } \\
\text { bumetanide }(\mathrm{ng} / \mathrm{ml}) \text {, } \\
\text { urinary excretion rate of } \\
\text { bumetanide }(\mu \mathrm{g} / \mathrm{h})\end{array}$ & {$[20]^{*}$} \\
\hline Bumetanide & Loop Diuretic & $\begin{array}{l}3 \text { humans } \\
\text { (healthy) }\end{array}$ & $1 \mathrm{mg}$ IR tablet po & Tolerance & $\begin{array}{l}\text { Urine flow } \\
\text { rate }(\mathrm{ml} / \mathrm{h})\end{array}$ & $\begin{array}{l}\text { Urinary excretion rate of } \\
\text { bumetanide }(\mu \mathrm{g} / \mathrm{h})\end{array}$ & {$[20]^{*}$} \\
\hline Cocaine & $\begin{array}{l}\text { Anesthetic/Drug of } \\
\text { abuse }\end{array}$ & 7 humans & $\begin{array}{l}\text { Smoked doses }(10,20, \\
\text { and } 40 \mathrm{mg})\end{array}$ & Tolerance (acute) & $\begin{array}{c}\text { Mean change } \\
\text { in systolic and } \\
\text { diastolic } \\
\text { pressure } \\
(\mathrm{mmHg})\end{array}$ & $\begin{array}{c}\text { Plasma cocaine } \\
\text { concentration }(\mathrm{ng} / \mathrm{ml})\end{array}$ & {$[299]^{*}$} \\
\hline Cocaine & Drug of abuse & $\begin{array}{l}9 \text { humans } \\
\text { (healthy) }\end{array}$ & $\begin{array}{l}\text { Smoked dose (12.5, } \\
\text { 25, and } 50 \mathrm{mg}) \text { and i.v. } \\
\text { doses }(8,16,32 \mathrm{mg})\end{array}$ & $\begin{array}{l}\text { Rapid distribution of } \\
\text { drug to the brain }\end{array}$ & $\begin{array}{l}\text { Mean change } \\
\text { in systolic and } \\
\text { diastolic } \\
\text { pressure } \\
\text { (BPM) and } \\
\text { ratings of } \\
\text { stimulated, } \\
\text { high or drug } \\
\text { liking }\end{array}$ & $\begin{array}{l}\text { Venous plasma cocaine } \\
\text { concentration }(\mathrm{ng} / \mathrm{ml})\end{array}$ & {$[300]^{*}$} \\
\hline Cyclohexylamine & $\begin{array}{l}\text { Sympathomimetic } \\
\text { amine }\end{array}$ & Rats & $\begin{array}{c}30 \text { or } 60 \mathrm{mg} / \mathrm{kg} \text { iv } \\
\text { infused over } 20 \mathrm{~min} \\
\text { or } 30,60, \text { or } 120 \\
\mathrm{mg} / \mathrm{kg} \text { infused over } 40 \\
\text { min }\end{array}$ & Tolerance (acute) & $\begin{array}{l}\text { Mean Arterial } \\
\text { Blood } \\
\text { Pressure } \\
(\mathrm{mmHg})\end{array}$ & $\begin{array}{l}\text { Plasma Cyclohexylamine } \\
(\mu \mathrm{g} / \mathrm{ml})\end{array}$ & [323] \\
\hline Cyclohexylamine & $\begin{array}{l}\text { Sympathomimetic } \\
\text { amine }\end{array}$ & Humans & $5 \mathrm{mg} / \mathrm{kg}$ po single dose & Tolerance & $\begin{array}{c}\text { Mean Arterial } \\
\text { Blood } \\
\text { Pressure } \\
(\mathrm{mmHg}) \\
\end{array}$ & $\begin{array}{l}\text { Plasma Cyclohexylamine } \\
(\mu \mathrm{g} / \mathrm{ml})\end{array}$ & [324] \\
\hline D-amphetamine & Stimulant & 22 rats & $\begin{array}{c}1.5 \mathrm{mg} / \mathrm{kg} \mathrm{D}- \\
\text { amfetamine base IR }\end{array}$ & None described & $\begin{array}{l}\text { Locomotor } \\
\text { activity } \\
\text { (min/15 min } \\
\text { interval) }\end{array}$ & $\begin{array}{l}\text { Dopamine concentration } \\
\text { in the striatum ( } \% \text { of } \\
\text { baseline) }\end{array}$ & {$[28]^{*}$} \\
\hline
\end{tabular}


J Pharm Pharm Sci (www.cspsCanada.org) 17(1) 34 - 91, 2014

\begin{tabular}{|c|c|c|c|c|c|c|c|}
\hline Diazepam & Benzodiazepine & $\begin{array}{l}17 \text { humans } \\
\text { (healthy) }\end{array}$ & $0.28 \mathrm{mg} / \mathrm{kg}$ & Tolerance & $\begin{array}{c}\text { Adjusted } \\
\text { subcritical } \\
\text { tracking (rms- } \\
\mathrm{cm}) \\
\text { Adjusted digit } \\
\text { symbol } \\
\text { substitution } \\
(\mathrm{sec}) \\
\end{array}$ & $\begin{array}{l}\text { Diazepam plasma level x } \\
\text { free fraction }(\mathrm{ng} / \mathrm{mL})\end{array}$ & {$[85]^{*}$} \\
\hline Diltiazem & $\begin{array}{c}\text { Non- } \\
\text { dihydropyridine } \\
\text { calcium channel } \\
\text { blocker }\end{array}$ & $\begin{array}{l}6 \text { humans } \\
\text { (healthy) }\end{array}$ & $\begin{array}{l}120 \mathrm{mg} \text { po single dose } \\
(2 \times 60 \mathrm{mg} \text { tablets })\end{array}$ & Tolerance & $\begin{array}{l}\text { PR change } \\
\quad(\mathrm{msec})\end{array}$ & $\begin{array}{l}\text { Diltiazem concentration } \\
(\mathrm{ng} / \mathrm{ml})\end{array}$ & [86] \\
\hline Diltiazem & $\begin{array}{c}\text { Non- } \\
\text { dihydropyridine } \\
\text { calcium channel } \\
\text { blocker } \\
\end{array}$ & $\begin{array}{l}20 \text { humans } \\
\text { (healthy) }\end{array}$ & $\begin{array}{c}180 \mathrm{mg} \text { SR capsule } \\
\text { with wax matrix } \\
180 \mathrm{mg} \text { SR tablet }\end{array}$ & Tolerance & $\begin{array}{c}\text { Changes in } \\
\text { PQ interval } \\
\text { (\% of } \\
\text { baseline) }\end{array}$ & $\begin{array}{c}\text { Diltiazem plasma } \\
\text { concentration }(\mathrm{ng} / \mathrm{ml})\end{array}$ & [87] \\
\hline $\begin{array}{l}\text { Distigmine } \\
\text { Bromide }\end{array}$ & $\begin{array}{l}\text { Long acting acetyl- } \\
\text { cholinesterase } \\
\text { inhibitor }\end{array}$ & Rats & $\begin{array}{c}0.3,1,3 \mathrm{mg} / \mathrm{kg} \\
\text { po (single dose) }\end{array}$ & $\begin{array}{c}\text { Time lag between } \\
\text { arrival of distigmine at } \\
\text { the site and the onset of } \\
\text { its inhibitory effect. }\end{array}$ & $\begin{array}{c}\text { AChE activity } \\
(\%)\end{array}$ & $\begin{array}{l}\text { Plasma Concentration of } \\
\text { distigmine }(\mathrm{ng} / \mathrm{ml})\end{array}$ & {$[88]$} \\
\hline Fentanyl & Opioid analgesic & Rats & $\begin{array}{c}15 \mu \mathrm{g} / \mathrm{kg} \\
\text { Nasal (pressurized } \\
\text { olfactory delivery } \\
\text { device) }\end{array}$ & Tolerance & $\begin{array}{l}\text { Analgesic } \\
\text { effect } \\
(\% \mathrm{MPE})\end{array}$ & Fentanyl (ng/ml) & {$[57]^{*}$} \\
\hline Furosemide & Loop diuretic & $\begin{array}{l}26 \text { humans } \\
\text { (healthy) }\end{array}$ & $\begin{array}{l}60 \mathrm{mg} \text { CR po } \\
\text { (two different } \\
\text { formulations) }\end{array}$ & Tolerance & $\begin{array}{l}\text { Diuresis } \\
(\mathrm{mL} / \mathrm{min})\end{array}$ & $\begin{array}{c}\text { Furosemide excretion rate } \\
\qquad(\mu \mathrm{g} / \mathrm{min})\end{array}$ & {$[38]^{*}$} \\
\hline Furosemide & Loop diuretic & $\begin{array}{l}8 \text { humans } \\
\text { (healthy) }\end{array}$ & $\begin{array}{c}10 \mathrm{mg} \text { iv infusion over } \\
\text { 30, } 100 \text { and } 300 \\
\text { minutes }\end{array}$ & Tolerance & $\begin{array}{c}\text { Diuresis } \\
(\mathrm{mL} / \mathrm{min}) \text { and } \\
\text { Natiuresis } \\
(\mathrm{mmol} / \mathrm{min})\end{array}$ & $\begin{array}{l}\text { Furosemide excretion rate } \\
(\mu \mathrm{g} / \mathrm{min})\end{array}$ & {$[41]^{*}$} \\
\hline Furosemide & Loop diuretic & $\begin{array}{l}4 \text { humans } \\
\text { (healthy) }\end{array}$ & $40 \mathrm{mg}$ SR tablet po & Tolerance & $\begin{array}{l}\text { Diuretic rate } \\
(\mathrm{ml} / \mathrm{h})\end{array}$ & $\begin{array}{l}\text { Excretion rate of } \\
\text { furosemide }(\mathrm{mg} / \mathrm{h})\end{array}$ & {$[39]^{*}$} \\
\hline Furosemide & Loop diuretic & $\begin{array}{l}11 \text { humans, } \\
\text { Middle Eastern } \\
\text { Arabs (healthy) } \\
12 \text { humans, } \\
\text { Asian (healthy) }\end{array}$ & $\begin{array}{c}40 \mathrm{mg} \text { tab po single } \\
\text { dose }\end{array}$ & Tolerance & $\begin{array}{l}\text { Chloride, } \\
\text { sodium, } \\
\text { calcium, } \\
\text { magnesium } \\
\text { and } \\
\text { potassium } \\
\text { excretion } \\
\text { rates }\end{array}$ & $\begin{array}{l}\text { Furosemide excretion rate } \\
\qquad(\mu \mathrm{g} / \mathrm{hr})\end{array}$ & {$[40]^{*}$} \\
\hline
\end{tabular}


J Pharm Pharm Sci (www.cspsCanada.org) 17(1) 34 - 91, 2014

\begin{tabular}{|c|c|c|c|c|c|c|c|}
\hline Furosemide & Loop diuretic & $\begin{array}{l}8 \text { humans } \\
\text { (healthy) }\end{array}$ & $\begin{array}{c}40 \text { mg iv after } \\
\text { breakfast } \\
40 \text { mg tablet po after } \\
\text { breakfast } \\
\end{array}$ & Tolerance & $\begin{array}{l}\text { Urine flow } \\
\text { rate }(\mathrm{mL} / \mathrm{min})\end{array}$ & $\begin{array}{l}\text { Furosemide excretion rate } \\
(\mu \mathrm{g} / \mathrm{min})\end{array}$ & [89] \\
\hline $\begin{array}{c}\text { Glutamate- } \\
\text { oxaloacetate } \\
\text { transaminase } \\
\text { (GOT) } \\
\text { Glutamate- } \\
\text { pyruvate } \\
\text { transaminase } \\
\text { (GPT) enzymes }\end{array}$ & $\begin{array}{l}\text { Enzymes that } \\
\text { metabolize } \\
\text { glutamate }\end{array}$ & 46 rats & $\begin{array}{c}\text { Single IV bolus } \\
\text { injections of } \\
0.03 \text { or } 0.06 \mathrm{mg} / \mathrm{kg} \\
\text { GOT } \\
0.6 \text { or } 1.2 \mathrm{mg} / \mathrm{kg} \mathrm{GPT}\end{array}$ & None described & $\begin{array}{l}\text { Blood } \\
\text { glutamate } \\
(\mu \mathrm{M})\end{array}$ & $\begin{array}{l}\text { Serum GOT or GPT } \\
(\mathrm{mg} / \mathrm{L})\end{array}$ & [90] \\
\hline Heparin & Anticoagulant & $\begin{array}{l}9 \text { humans } \\
\text { (healthy) }\end{array}$ & $\begin{array}{l}2000 \text { IU continuous } \\
\text { infusion over } 40 \mathrm{~min}\end{array}$ & $\begin{array}{c}\text { Tolerance } \\
\text { - may be caused by } \\
\text { depletion of endothelial } \\
\text { TFPI sources }\end{array}$ & $\begin{array}{c}\text { Plasma } \\
\text { concentration } \\
\text { of TFPI (free } \\
\text { and total) } \\
\left(\mathrm{ng} \mathrm{m}^{-1}\right) \\
\text { TFPI } \\
\text { production } \\
\text { rate }\left(\mu \mathrm{g} \mathrm{min} \text { min }^{-}\right. \\
\left.{ }^{1}\right)\end{array}$ & $\begin{array}{l}\text { Anti-IIa activity }\left(\mathrm{U} \mathrm{ml}^{-1}\right) \\
\text { a measure of heparin } \\
\text { concentration }\end{array}$ & [91] \\
\hline $\begin{array}{c}(+/-) \\
\text { Irbesartan }\end{array}$ & $\begin{array}{l}\text { Angiotensin II } \\
\text { receptor blocker }\end{array}$ & $\begin{array}{l}24 \text { humans (mild } \\
\text { to moderate } \\
\text { hypertension) }\end{array}$ & $\begin{array}{l}300 \mathrm{mg} \text { po once daily } \\
\text { for } 4 \text { weeks }\end{array}$ & $\begin{array}{c}\text { Central-effect } \\
\text { compartment } \\
\text { Receptor antagonism }\end{array}$ & $\begin{array}{l}\text { Seated } \\
\text { diastolic } \\
\text { blood } \\
\text { pressure }\end{array}$ & $\begin{array}{l}\text { Mean irbesartan } \\
\text { concentration }(\mathrm{ng} / \mathrm{ml})\end{array}$ & {$[92]^{*}$} \\
\hline $\begin{array}{c}(+/-) \\
\text { Meperidine }\end{array}$ & Opioid analgesic & Sheep & $\begin{array}{l}100 \mathrm{mg} \text { iv dose over } 1 \\
\text { second }\end{array}$ & Tolerance & $\begin{array}{l}\text { Contractility } \\
\text { (\% reduction) }\end{array}$ & $\begin{array}{c}\text { Concentrations of } \\
\text { meperidine in } \\
\text { myocardium and coronary } \\
\text { sinus blood }(\mathrm{mg} / \mathrm{L})\end{array}$ & {$[53]^{*}$} \\
\hline $\begin{array}{c}(+/-) \\
\text { Methylphenidate }\end{array}$ & $\begin{array}{l}\text { Central Nervous } \\
\text { System Stimulant }\end{array}$ & 4 rats & $\begin{array}{l}2,5,10 \mathrm{mg} / \mathrm{kg} \text { iv } \\
\text { (three doses) }\end{array}$ & $\begin{array}{l}\text { Tolerance or } \\
\text { Desensitization }\end{array}$ & $\begin{array}{l}\text { Dopamine } \\
\text { ratio to basal }\end{array}$ & $\begin{array}{c}\text { Methylphenidate } \\
\text { concentration in dialysate } \\
(\mathrm{ng} / \mathrm{ml})\end{array}$ & [93] \\
\hline Metolazone & $\begin{array}{l}\text { Thiazide-related } \\
\text { diuretic }\end{array}$ & $\begin{array}{c}5 \text { humans (renal } \\
\text { transplant } \\
\text { patients) } \\
5 \text { humans } \\
\text { (creatinine } \\
\text { clearance }\end{array}$ & $5 \mathrm{mg}$ & $\begin{array}{c}\text { Tolerance to diuretic } \\
\text { effect }\end{array}$ & $\begin{array}{l}\text { Sodium } \\
\text { Excretion rate } \\
(\mathrm{meq} / \mathrm{min})\end{array}$ & $\begin{array}{l}\text { Urinary metolazone } \\
\text { excretion rate (ng/min) }\end{array}$ & [94] \\
\hline $\begin{array}{c}(+/-) \\
\text { Morphine }\end{array}$ & Opioid analgesic & Rats & $\begin{array}{c}2.5 \mathrm{mg} / \mathrm{kg} \\
\text { Nasal (pressurized } \\
\text { olfactory delivery } \\
\text { device) }\end{array}$ & Tolerance & $\begin{array}{l}\text { Analgesic } \\
\text { effect } \\
(\% \mathrm{MPE})\end{array}$ & Morphine (ng/ml) & {$[57]^{*}$} \\
\hline
\end{tabular}




\begin{tabular}{|c|c|c|c|c|c|c|c|}
\hline $\begin{array}{c}(+/-) \\
\text { Morphine }\end{array}$ & Opioid analgesic & 280 rats & $\begin{array}{l}15 \mathrm{mg} / \mathrm{kg} \text { through } \\
\text { intragastric } \\
\text { administration } \\
\text { (single dose) }\end{array}$ & $\begin{array}{l}\text { Tolerance due to drug } \\
\text { induced desensitization } \\
\text { of receptors or counter } \\
\text { regulatory substances }\end{array}$ & $\begin{array}{l}\text { \% MPE on } \\
\text { TPR (thermal } \\
\text { pain } \\
\text { response) }\end{array}$ & $\begin{array}{l}\text { Concentration of blood } \\
\text { morphine }(\mu \mathrm{g} / \mathrm{L}), \text { and } \\
\text { concentration of CSF } \\
\text { morphine }(\mu \mathrm{g} / \mathrm{L}), \text { both } \\
\text { conjugated and } \\
\text { unconjugated } \\
\end{array}$ & {$[59]^{*}$} \\
\hline Nefopam & $\begin{array}{l}\text { Non-opioid } \\
\text { analgesic }\end{array}$ & $\begin{array}{l}24 \text { humans } \\
\text { (healthy) }\end{array}$ & $\begin{array}{l}20 \mathrm{mg} \text { po and iv } \\
\text { (single doses) }\end{array}$ & None described & $\begin{array}{l}\text { Visual analog } \\
\text { scale drowsy } \\
\quad(\mathrm{mm})\end{array}$ & $\begin{array}{c}\text { Nefopam plasma } \\
\text { concentration (nM), } \\
\text { desmethyl-nefopam } \\
\text { plasma concentration } \\
\text { (nM) }\end{array}$ & {$[95]$} \\
\hline (+/-) Nicotine & Stimulant & $\begin{array}{l}8 \text { humans } \\
\text { (healthy) }\end{array}$ & $\begin{array}{c}2.5 \mu \mathrm{g} / \mathrm{kg} / \mathrm{min} \text { iv for } \\
30 \mathrm{~min}, 120 \mathrm{~min} \text {, and } \\
210 \mathrm{~min}\end{array}$ & Tolerance & $\begin{array}{l}\text { Heart rate } \\
\text { (BPM) }\end{array}$ & $\begin{array}{c}\text { Blood nicotine } \\
\text { concentration }(\mathrm{ng} / \mathrm{ml})\end{array}$ & [315] \\
\hline Pancuronium & $\begin{array}{l}\text { Neuromuscular } \\
\text { blocking agent }\end{array}$ & $\begin{array}{l}5 \text { humans } \\
\text { (healthy) }\end{array}$ & $4 \mathrm{mg}$ iv & Effect compartment & $\begin{array}{l}\text { \% twitch } \\
\text { depression }\end{array}$ & $\begin{array}{c}\text { Pancuronium } \\
\text { concentration }(\mathrm{nmol} / \mathrm{L})\end{array}$ & {$[316]^{*}$} \\
\hline Piritramide & $\begin{array}{l}\text { Synthetic opioid } \\
\text { analgesic }\end{array}$ & $\begin{array}{l}24 \text { humans } \\
\text { (post-abdominal } \\
\text { surgery) }\end{array}$ & $\begin{array}{l}7 \mu \mathrm{g} \mathrm{kg}^{-1} \mathrm{~min}^{-1} \text { up to } \\
\text { maximum } 0.2 \mathrm{mg} / \mathrm{kg}\end{array}$ & $\begin{array}{l}\text { Equilibration delay of } \\
\text { piritramide between } \\
\text { plasma concentration } \\
\text { and effect site }\end{array}$ & $\begin{array}{c}\text { Pain intensity } \\
\text { VAS } \\
\text { measured (0- } \\
100) \\
\text { Pain intensity } \\
\text { VAS } \\
\text { predicted } \\
(0-100)\end{array}$ & $\begin{array}{c}\text { Piritramide concentration } \\
\text { measured }(\mu \mathrm{g} / \mathrm{L}) \\
\text { Piritramide concentration } \\
\text { measured }(\mu \mathrm{g} / \mathrm{L})\end{array}$ & [96] \\
\hline Propofol & General Anesthetic & 18 rats & $150 \mathrm{mg} / \mathrm{kg} \cdot \mathrm{h}$ & $\begin{array}{l}\text { Delay of equilibrium of } \\
\text { blood and effect site }\end{array}$ & $\begin{array}{l}\text { Electroenceph } \\
\text { alographic } \\
\text { amplitude }\end{array}$ & $\begin{array}{l}\text { Propofol blood } \\
\text { concentration }\end{array}$ & {$[97]^{*}$} \\
\hline Propofol & General Anesthetic & Rats & $\begin{array}{l}30 \mathrm{mg} / \mathrm{kg} \text { in } 5 \mathrm{~min} \text { iv } \\
\text { bolus infusion and } 150 \\
\mathrm{mg} / \mathrm{kg} \text { iv continuous } \\
\text { infusion }(5 \mathrm{hrs}) \\
\text {-both doses tested as } \\
1 \% \text { in Intralipid } \AA \\
10 \%, 1 \% \text { in } \\
\text { Lipofundin } \AA \text { and } 6 \% \\
\text { in Lipofundin }{ }^{\circledR} \\
\text { emulsions }\end{array}$ & $\begin{array}{l}\text { Hypothetical multiple } \\
\text { compartments }\end{array}$ & EEG effects & $\begin{array}{c}\text { Propofol blood } \\
\text { concentration }(\mu \mathrm{g} / \mathrm{ml})\end{array}$ & {$[98]^{*}$} \\
\hline (+/-) Propranolol & Beta-blocker & $\begin{array}{l}8 \text { humans } \\
\text { (detoxified } \\
\text { alcoholics) }\end{array}$ & $80 \mathrm{mg}$ po & Acute tolerance & $\begin{array}{c}\text { Degree of } \\
\text { beta- } \\
\text { blockade, } \\
\text { changes in } \\
\text { heart rate }(\%)\end{array}$ & $\begin{array}{l}\text { Propranolol plasma } \\
\text { concentration (ng/ml) }\end{array}$ & {$[317]^{*}$} \\
\hline
\end{tabular}




\begin{tabular}{|c|c|c|c|c|c|c|c|}
\hline Remifentanil & $\begin{array}{l}\text { Synthetic opioid } \\
\text { analgesic }\end{array}$ & $\begin{array}{l}10 \text { humans } \\
\text { (healthy) }\end{array}$ & $\begin{array}{c}3 \mu \mathrm{g} / \mathrm{kg} / \min \text { for } 10 \\
\text { minutes }\end{array}$ & $\begin{array}{l}\text { Equilibration between } \\
\text { arterial drug } \\
\text { concentration and the } \\
\text { effect site occurs more } \\
\text { rapidly than equilibrium } \\
\text { between arterial drug } \\
\text { concentration and } \\
\text { venous drug } \\
\text { concentration }\end{array}$ & $\begin{array}{l}\text { Spectral edge } \\
\quad(\mathrm{Hz}) \\
\text { (opioid effect) }\end{array}$ & $\begin{array}{l}\text { Venous remifentanil } \\
\text { concentration }(\mathrm{ng} / \mathrm{mL})\end{array}$ & {$[69]^{*}$} \\
\hline Scopolamine & Anticholinergic & $\begin{array}{l}90 \text { humans } \\
\text { (healthy) }\end{array}$ & $\begin{array}{l}0.5 \mathrm{mg} \text { iv infusion } \\
\text { over } 15 \mathrm{~min} .\end{array}$ & $\begin{array}{l}\text { Delayed distribution to } \\
\text { effect compartment }\end{array}$ & $\begin{array}{l}\text { Saccadic peak } \\
\text { velocity }\left({ }^{\circ} \mathrm{s}^{-1}\right) \\
\text { VAS alertness } \\
(\mathrm{mm})\end{array}$ & $\begin{array}{l}\text { Plasma scopolamine } \\
\text { concentration }\left(\mathrm{pg} \mathrm{ml}^{-1}\right)\end{array}$ & [99] \\
\hline $\begin{array}{c}\text { Sodium } \\
\text { dichloroacetate }\end{array}$ & $\begin{array}{l}\text { Acetic acid } \\
\text { analogue }\end{array}$ & $\begin{array}{l}37 \text { humans } \\
\text { (healthy) }\end{array}$ & $\begin{array}{c}30 \mathrm{mg} / \mathrm{kg}, 60 \mathrm{mg} / \mathrm{kg} \text { or } \\
100 \mathrm{mg} / \mathrm{kg} \text { iv infusions } \\
\text { over } 30 \mathrm{~min}\end{array}$ & $\begin{array}{l}\text { 1) Inhibition of PDH- } \\
\text { kinase could be } \\
\text { reversible at low } \\
\text { concentrations of DCA, } \\
\text { becoming } \\
\text { irreversible at high } \\
\text { concentration } \\
\text { 2) PDH-kinase binding } \\
\text { of DCA may be more } \\
\text { rapid than dissociation } \\
\text { 3) There may be } \\
\text { Substantial redundancy } \\
\text { in the amounts of DCA } \\
\text { bound compared } \\
\text { with that needed for } \\
\text { maximal effect, or 4) A } \\
\text { combination } \\
\text { of these fairly common } \\
\text { pharmacological } \\
\text { phenomena }\end{array}$ & $\begin{array}{l}\text { Serum lactate } \\
\text { concentration } \\
(\mathrm{mM})\end{array}$ & $\begin{array}{c}\text { Serum Sodium } \\
\text { dichloroacetate } \\
\text { concentration }(\mu \mathrm{g} / \mathrm{mL})\end{array}$ & [100] \\
\hline Spiraprilat & $\begin{array}{l}\text { Active metabolite of } \\
\text { spirapril (ACEI) }\end{array}$ & 8 humans $(\mathrm{CHF})$ & $6 \mathrm{mg}$ po of spirapril & None described & $\begin{array}{l}\text { Pulmonary } \\
\text { capillary } \\
\text { wedge } \\
\text { pressure } \\
\text { (mmHg) }\end{array}$ & $\begin{array}{l}\text { Spiraprilat plasma } \\
\text { concentration }(\mathrm{ng} / \mathrm{ml})\end{array}$ & [330] \\
\hline
\end{tabular}


J Pharm Pharm Sci (www.cspsCanada.org) 17(1) 34 - 91, 2014

\begin{tabular}{|c|c|c|c|c|c|c|c|}
\hline$(+/-)$ Temazepam & Benzodiazepine & $\begin{array}{l}11 \text { humans (end- } \\
\text { stage renal } \\
\text { disease) }\end{array}$ & $\begin{array}{l}30 \text { mg capsule po (two } \\
\text { single doses) }\end{array}$ & $\begin{array}{c}\text { Tolerance- discrepancy } \\
\text { between plasma t } 1 / 2 \\
\text { and binding affinity }\end{array}$ & $\begin{array}{l}\text { Sedation } \\
\text { score } \\
\text { NRSS Nurse } \\
\text { rated sedation } \\
\text { score (range } \\
\text { 0- wide } \\
\text { awake to 4- } \\
\text { sleeping } \\
\text { soundly, not } \\
\text { awakened by } \\
\text { blood } \\
\text { sampling) }\end{array}$ & $\begin{array}{l}\text { Temazepam concentration } \\
(\mathrm{ng} / \mathrm{ml})\end{array}$ & [101] \\
\hline $\begin{array}{c}(+/-) \\
\text { Zopiclone }\end{array}$ & $\begin{array}{l}\text { Short-acting } \\
\text { hypnotic }\end{array}$ & $\begin{array}{l}10 \text { humans } \\
\text { (healthy) }\end{array}$ & $7.5 \mathrm{mg}$ po single dose & $\begin{array}{l}\text { Tolerance or pseudo- } \\
\text { tolerance }\end{array}$ & $\begin{array}{l}\text { Saccadic peak } \\
\text { velocity and } \\
\text { Digital } \\
\text { symbol } \\
\text { substitution } \\
\text { test } \\
\text { (sedation } \\
\text { scores) }\end{array}$ & $\begin{array}{l}\text { Blood sample from } \\
\text { forearm vein zopiclone } \\
(\mathrm{ng} / \mathrm{ml})\end{array}$ & [102] \\
\hline
\end{tabular}

+/- Indicates Racemic Drug with Enantiomers * Indicates Drug listed in both Table 2 and 3 
